NBER WORKING PAPER SERIES

CAPITAL FLOWS IN RISKY TIMES:

RISK-ON/RISK-OFF AND EMERGING MARKET TAIL RISK

\author{
Anusha Chari \\ Karlye Dilts Stedman \\ Christian Lundblad \\ Working Paper 27927 \\ http://www.nber.org/papers/w27927 \\ NATIONAL BUREAU OF ECONOMIC RESEARCH \\ 1050 Massachusetts Avenue \\ Cambridge, MA 02138 \\ October 2020
}

The views expressed herein are those of the authors and do not necessarily reflect the views of the National Bureau of Economic Research.

NBER working papers are circulated for discussion and comment purposes. They have not been peer-reviewed or been subject to the review by the NBER Board of Directors that accompanies official NBER publications.

(C) 2020 by Anusha Chari, Karlye Dilts Stedman, and Christian Lundblad. All rights reserved. Short sections of text, not to exceed two paragraphs, may be quoted without explicit permission provided that full credit, including $\odot$ notice, is given to the source. 
Capital Flows in Risky Times: Risk-on/Risk-off and Emerging Market Tail Risk

Anusha Chari, Karlye Dilts Stedman, and Christian Lundblad

NBER Working Paper No. 27927

October 2020

JEL No. F21,F3,G15

\begin{abstract}
$\underline{\text { ABSTRACT }}$
This paper characterizes the implications of risk-on/risk-off shocks for emerging market capital flows and returns. We document that these shocks have important implications not only for the median of emerging markets flows and returns but also for the left tail. Further, while there are some differences in the effects across bond vs. equity markets and flows vs. asset returns, the effects associated with the worst realizations are generally larger than that on the median realization. We apply our methodology to the COVID-19 shock to examine the pattern of flow and return realizations: the sizable risk-off nature of this shock engenders reactions that reside deep in the left tail of most relevant emerging market quantities.
\end{abstract}

Anusha Chari

Department of Economics, CB \#3305

University of North Carolina at Chapel Hill

Chapel Hill, NC 27599

and NBER

achari@unc.edu

Karlye Dilts Stedman

Federal Reserve Bank of Kansas

1 Memorial Dr.

Kansas City, MO 64108

karlye.stedman@kc.frb.org
Christian Lundblad

Department of Finance

University of North Carolina at Chapel Hill

Chapel Hill, NC 27599-3490

christian_lundblad@unc.edu 


\section{Introduction}

While portfolio flows to emerging markets offer well-documented benefits (Bekaert, Harvey and Lundblad (2005); Chari and Henry (2004, 2008); Henry (2007)), tail events such as sudden stops present challenges that prove particularly pressing for investors and policy makers (Forbes and Warnock (2012, 2019); Rey (2013); Miranda-Agrippino and Rey (2020)). There is, of course, a large literature on cross-border capital flows and their implications for financial market returns. $1^{1}$ However, extant research has largely focused on the first moment of the relevant distributions of these important quantities. In sharp contrast, building on Gelos et al. (2019), we focus on the full distributions of emerging market capital flows and returns; most important, we characterize the manner in which extreme capital flow and returns realizations are tied to global risk appetite ("risk-on/risk-off" or RORO).

Despite still being somewhat imprecisely defined, the RORO terminology has come into pervasive use in the financial press and among policy makers in the years since the global financial crisis. In this paper, we focus on RORO shocks as a reflection of variation in global investor risk aversion. As investors rebalance their portfolios away from risk assets and toward safe assets in the face of risk aversion shock, RORO variation has important implications for asset price determination, particularly for so-called "risk assets". Jotikasthira, Lundblad, and Ramadorai (2012), for example, document this shock transmission mechanism to emerging market capital flows and asset prices. In response to funding shocks from their investor base (possibly linked to RORO), global funds substantially alter their portfolio alloca-

\footnotetext{
${ }^{1}$ See for example a non-exhaustive list of papers in Section 1 of the online appendix, Alfaro, L., S. KalemliOzcan, and V. Volosovych (2008, 2014); Avdjiev, S., L. Gambacorta, L. S. Goldberg, and S. Schiaffi (2017); Ammer, J., M. De Pooter, C. J. Erceg, and S. B. Kamin (2016); Baskaya, Y. S., J. di Giovanni, S. Kalemli-Ozcan, J.-L. Peydro, and M. F. Ulu (2017); Bauer, M. D., \& Neely, C. J. (2014); Broner, F., Didier, T., Erce, A., \& Schmukler, S. L. (2013); Bruning, F. and V. Ivashina (2019); Bruno, V. and H. S. Shin (2014, 2015); Calvo, G. A., L. Leiderman, and C. M. Reinhart (1993, 1996); Cerutti, E., S. Claessens, and D. Puy (2019); Chari, A., K. Dilts Stedman, and C. Lundblad (2020); Chen, J., Mancini Griffoli, T., \& Sahay, R. (2014); Clark, John, Nathan Converse, Brahima Coulibaly, and Steve Kamin (2016); Dedola, L., G. Rivolta, and L. Stracca (2017); Dilts Stedman, K. (2019); Eichengreen, B. and P. Gupta (2017); Forbes, K. J. and F. E. Warnock (2012, 2019); Fratzscher, M. (2012); Fratzscher, M., Duca, M. L., \& Straub, R. (2016, 2018); Georgiadis, G., \& Grab, J. (2015); Ghosh, A. R., Kim, J., Qureshi, M., and Zalduendo, J. (2012); Gilchrist, S., Yue, V., \& Zakrajsek, E. (2014, November); Gourinchas, P. O., \& Obstfeld, M. (2012); Karolyi, G. A., \& McLaren, K. J. (2016); Kim, S. (2001); Kroencke, T. A., Schmeling, M., \& Schrimpf, A. (2015); Jotikasthira, P., C. Lundblad, and T. Ramadorai (2012); McCauley, R. N., McGuire, P., \& Sushko, V. (2015); Miranda-Agrippino, S. and H. Rey (2019); Milesi-Ferretti, G., \& Tille, C. (2011); Mishra, P., Moriyama, K., N’Diaye, P. M. B., \& Nguyen, L. (2014); Moore, J., Nam, S., Suh, M., \& Tepper, A. (2013); Neely, C. J. (2010); Obstfeld, M. (2015); Obstfeld, M., J. D. Ostry, and M. S. Qureshi (2018); Rogers, J.H., Scotti,C., \& Wright,J.H.(2014); Reinhart, C. and V. Reinhart (2009); Rey, H. (2013).
} 
tions to emerging markets with important implications for local asset prices.

To capture realized variation in global investor risk appetite, we consider two complementary approaches to RORO measurement. The first is a RORO index that we build using the first principle component of daily data from both the United States and the Euro area. This approach has the advantage of incorporating a multi-faceted set of signals from relevant asset markets, but it may confound information about variation in risk appetite with variation in physical risk. To address this, we consider a complementary model-based approach from Bekaert at al. (2020). This has the advantage of measuring risk aversion using a structural model specifically designed to separate the price of risk (or risk aversion) from the quantity of risk. However, inference about this separation may, of course, be contaminated by any model mis-specfication. Given these competing concerns, we consider both approaches to gauge the extent to which we can draw relatively robust conclusions regarding the effect of RORO shocks on emerging market flows and returns.

Using our first (largely statistical) approach, we summarize the risk-on and risk-off states of the world with an amalgam of four broad categories that reflect variation in advanced economy credit risk, equity market volatility, funding conditions, and currencies and gold. With an eye to inferring the risk bearing capacity of international investors, our RORO index comprises the first principle component of daily changes in these series. Our index, along with several associated sub-indices reflecting these four constituent groups, exhibits interesting distributional features in the sense that it is well characterized by significant skewness and fat tails. With fat tails, extreme events become both more probable and potentially more destabilizing. As examples, we observe sharp risk-off movements during the global financial crisis, the European debt crisis, the taper tantrum, and the COVID-19 crisis.

Second, in recognition of the fact that our RORO measure reflects a largely statistical approach to measuring risk appetite, we also consider the measure of risk aversion from Bekaert at al. (2020). As with our first RORO index, this model-based measure is also highly rightskewed and fat tailed, spiking during the global financial and COVID-19 crises.

Understanding the implications of variation in RORO for emerging market capital flow and return distributions is the focus of our paper. We focus on the extent to which RORO shocks alter the range of the distribution versus shift the distribution. As an example, an ad- 
verse, risk-off shock can make the whole emerging market capital flow or return distribution wider by pulling out both of the tails. Alternatively, a risk-off shock could simply fatten the left tail. These differences have important implications for how investors and policy makers should consider downside risk.

Using a panel quantile regression approach as in Machado and Santos Silva (2019), we characterize the distributional implications of RORO shocks for emerging market capital flows and returns. In order to obtain a multilateral, high frequency proxy of capital flows into and out of emerging markets, we use the country flows dataset from EPFR Global. EPFR Global publishes weekly portfolio investment flows by more than 14,000 equity funds and more than 7,000 bond funds, collectively with more than 8 trillion U.S. dollars of capital under management. To measure returns on emerging market assets, we use country level USD and local currency equity return indices from MSCI, and our fixed income returns come from Bloomberg local currency bond indices and the USD Emerging Market Bond Index from JP Morgan. Due to the availability of EPFR data, the sample runs from January 7, 2004 to Apr. 9, 2020.

The novel contribution of our paper is to characterize the impact of shifts in the distributions of global risk on flows and returns as well as the dispersion in outcomes. In other words, our methodology allows us to model both shifts and changes in the shapes of the distributions of global push factors and capital flow and return outcomes. We conclude that with a few exceptions, the emphasis on measures of central tendency in the existing literature on capital flows masks important underlying heterogeneity in the full distribution of global risk. The weight placed on means and variances as sufficient summary statistics precludes the data from speaking to the underlying distributional granularity of global risk - a challenge we overcome by turning to heterogeneous effects across quantiles ${ }^{2}$

In addition to our focus on the distribution of global risk, our composite risk measure illustrates that the underlying factors that constitute global risk can differ across crises and evolve over time. We find that while advanced economy equity returns and volatility along with corporate spreads proxying for credit risk were the most significant risk factors during

\footnotetext{
${ }^{2}$ The approach is similar to that taken in Adrian et al. (2019) characterizing "GDP-at-Risk" effects that vary across quantiles.
} 
the global financial crisis, movement in corporate spreads and stoppages in funding liquidity predominantly explain capital flows and returns in the aftermath of Covid-19 shock. The corporate spreads factor during the Covid-era are an order of magnitude compared to the global financial crisis. The risk-aversion factor was more prominent in the global financial crisis relative to the quantity of risk, while the opposite prevails during the Covid crisis.

Regardless of the method by which we measure RORO, we find that RORO shocks do have important implications, not only for the median of emerging market flows and returns, but also for the tails. We conclude that the focus in the literature on measures of central tendency is incomplete. In particular, we find that the effects associated with the worst realizations, say the fifth quantile, are often more heavily affected by risk-off shocks, compared to the median realization.

We first consider the distributional implications for cross-border flows associated with EPFR bond and equity mutual funds. For bond funds, risk-off shocks (however measured) increase the worst portfolio outflow realizations more than they decrease median flows, and therefore risk-off shocks significantly fatten the left tail of the portfolio flow distribution. The net effect on bond flows from a risk-off event is that the entire distribution moves to the left. In the equity fund space, in contrast, while we observe that a risk-off shock negatively affects the overall distribution, we also observe that a risk-off shock modestly brings in both the tails. Further, the focus on the estimates derived from the model-based version of RORO suggest that the reactions that we observe, while robust from a directional standpoint, do vary depending upon whether one separates out variation in risk aversion from variation in risk. Perhaps not surprisingly, variation in global risk is also important for emerging market mutual fund flows.

Next, we turn to the distributional implications for emerging market returns. We find that risk-off shocks negatively affect the worst return realizations more than they affect the median return realization. Further, we find that are important differences across asset class and currency denomination which are constitent across risk measures. Equity returns are more sensitive than bond returns, and within asset classes, U.S. dollar indices are more sensitive than local currency indices.

Finally, we apply our framework to the COVID-19 shock. We examine the distributional 
pattern of the flow and returns realizations in the face of the sizable risk-off nature of this shock. In the COVID-19 era, a one standard deviation RORO shock expands (compresses) the tail realizations of the weekly bond (equity) distribution by $\$ 45$ (\$6.8) million. A shock equal in magnitude to the largest observation in the COVID-19 sample expands (compresses) the tails realizations of the weekly bond (equity) distribution by \$170.2 (\$25.4) million. Using the structural measure of risk aversion and risk from Bekaert et al (2020), our results suggest that a one standard deviation shock composed of equal parts risk aversion and physical risk separates the tails of the weekly bond (equity) distribution by $\$ 15.8$ (\$40.4) million.

Related Literature: Our paper is related to several strands of the literature on capital flows to emerging markets. There is a vast literature on the role of global financial market conditions and boom-bust cycles in emerging market capital flows and returns $3^{3}$ This literature emphasizes the role of global push factors to explain the ebbs and flows in foreign investment allocations to emerging markets.

Global financial conditions that serve as push factors include advanced economy monetary policy, foreign investor risk aversion, international financial market liquidity, and exchange rate configurations. Forbes and Warnock $(2012,2019)$ show that global risk factors drive emerging market capital flow surges, sudden stops and retrenchments. Jotikasthira et al. (2012) report that "global funds substantially alter portfolio allocations in emerging markets in response to funding shocks from their investor base.' ${ }^{4}$ Our paper contributes to the literature on extreme capital flow movements by focusing on the distributions of capital flows and returns conditional on the distribution of global risk factors.

There are different views in the literature about what constitutes or summarizes changes to global risk sentiment. At the same time, the provenance of risk can differ over time. Focusing on market risk and investor sentiment, Bekaert et al. (2013), Miranda-Agrippino and Rey (2019) and many others use the VIX as a proxy to measure the risk appetite of global investors. Fratzscher (2012) includes the TED spread as a measure of credit risk and liquidity

\footnotetext{
${ }^{3}$ A non-exhaustive list includes Tornell and Schneider, 2007; Mendoza and Terrones, 2008; Mendoza 2010; Obstfeld 2012; Diaz-Alejandro 1983; Calvo et al. 1993; Calvo et al. 1996; Eichengreen and Portes 1987; Reinhart and Reinhart 2009; Reinhart and Rogoff 2009.

${ }^{4}$ Evidence suggests that spillovers from the U.S. to the rest of the world operate through changes in risk premia that drive foreign investor risk tolerance (Borio and Zhu 2012). Caballero and Simsek (2019) provide a model for analyzing capital flow retrenchments to highlight their fickleness, possibly related to asymmetric information or Knightian uncertainty.
} 
in international capital markets. Chari et al. (2020) use of high-frequency identification to extract U.S. monetary policy shocks using Treasury derivatives data to show that capital flows to emerging markets are sensitive to term premium shocks in the U.S. yield curve. In this paper, we examine an amalgam of global shocks that collectively comprise global "risk-on" or risk-off environments in international financial markets to investigate the distributional implications of emerging market capital flows and returns. To do so, our aim is also to arrive at a measure of risk encapsulating the multi-faceted nature of global risk-on and risk-off states of the world.

In doing so, our paper draws upon existing evidence documenting the relationship between unitary risk sources and risk appetite. One strand of the literature examines the impact of U.S. monetary policy on global investor risk appetite (Bruno and Shin, 20015 a,b; Chari et al., 2020; Gourinchas and Obstfeld, 2012). Bekaert et al., 2013; Miranda-Agrippino and Rey, 2019; and Bruno and Shin, 2015a) show that U.S. monetary policy changes impact global risk. Expansionary monetary policy corresponds to global "risk-on" while tightening monetary policy shocks correlate with "risk-off" states of the world. Risk-on and risk-off states correspond to changes in risk aversion holding fixed the quantity of risk. Our approach has the advantage of measuring risk aversion using a structural model from Bekaert et. al. (2020) that disentangles the price of risk (or risk aversion) from the quantity of risk $5^{5}$ This literature emphasizes the role risk premia as drivers of capital flows to emerging markets. Chari et al. (2020) disentangle the channels through which U.S. monetary policy shocks can alter expectations hypothesis-driven yields and risk premia in the term structure of U.S. interest rates. Via portfolio rebalancing and signaling, changes in domestic yields and risk premia can have a significant impact on equity prices and bond yields in emerging markets. Bruno and Shin $(2015 \mathrm{a}, \mathrm{b})$ propose an international risk-taking channel that underscores the role of liquidity in dollar funding markets-phases of expansionary monetary policy increase the risk-bearing capacity of financial intermediaries and drives international banking flows to emerging markets.

To proxy for global risk aversion, the literature documents the sensitivity of portfolio eq-

\footnotetext{
${ }^{5}$ However, inference about this decomposition could suffer from the drawback that the model is incorrectly specified.
} 
uity flows to the VIX (Avdjiev et al. 2019; Rey 2015). Recent evidence draws attention to the diminished relationship between the VIX and other key variables after 2008 (Forbes, 2020; Miranda-Agrippino and Rey, 2020, Burcu et. al 2020). Avdjiev et al. (2017) attribute the declining role of the VIX to the shifting composition of global capital flows. Cerutti et al. (2019) suggest that correlation between the VIX and capital flows is limited to times of crisis and that the role for the global financial cycle may have moderated. Burcu et. al (2020) point to a breakdown in the negative relationship between bank leverage and risk appetite since 2009 suggesting that the VIX is no longer a reliable proxy for the price of bank balance sheets. Forbes and Warnock (2020) and Miranda-Agrippino et al. (2020) highlight a declining role in the information content of the VIX for explaining credit growth and capital flows. In contrast, the parameter values using our composite risk-on risk-off measure are remarkably stable (if not stronger) over time given that the measure captures alternative sources of risk. The underlying constituent sources of risk assert their importance or come to the forefront at different points in time.

Our nearest neighbors in the literature are Gelos et. al (2019) who examine a "capital flows-at-risk" model using a quantile regression framework, and Eguren-Martin et al (2020), who examine the probability distribution of emerging market capital flows conditional on information contained in financial asset prices. Both papers propose to characterize the full distribution of capital flows in the face of shocks. Our paper differs from these in several ways. First, using weekly data on flows and returns and daily risk measures, the frequency of our outcome variables matches more closely to the risk measures. We thereby establish a tighter link between the risk measure and our variables of interest, with less potential for confounding influences between the measure of the flow or return, and the event(s) driving changes in risk or risk aversion.

Second, we focus our attention on global risk in particular, rather than taking a broader look at "push" and "pull" factors, which Gelos et al (2019) consider individually and which Eguren-Martin et al (2020) consider in a consolidated manner. Considering the former, a multifaceted measure of risk confers the advantages discussed previously compared to a unitary risk measure like the BBB corporate spread used in Gelos et al (2019); namely, variable sources of risk, geographic diversity, and plausible exogeneity. Eguren-Martin et al (2020) take an 
approach more in line ours by putting forward the degree to which capital flows respond to many types and sources of shocks, but their single-dimensional measure of global risk (in additional to a local risk factor calculated as a residual) does not allow for a decomposition into global risk drivers. Likewise, our paper acknowledges, and attempts to characterize, the distinction between risk and risk aversion in shaping outcomes within the distribution.

The paper proceeds as follows. Section 2 outlines the data and methodology for computing our risk-on risk off measures. Section 3 presents our baseline specification and the results from our quantile regression analysis. Section 4 presents a quantitative exercise which demonstrates the distributional implications of our findings applied to the the Covid-19 crisis. Section 5 concludes.

\section{The Data}

\subsection{Computing Risk-on/Risk-off}

To capture realized variation in global investor risk appetite, we consider two complementary measures of Risk-On, Risk-Off (RORO). First, we build a measure from the first principle component of a multi-faceted set of daily data across several relevant asset markets. While definitely linked to variation in risk aversion, this measure may nevertheless confound information about variation in risk appetite with variation in physical risk. Hence, we also consider a complementary model-based approach from Bekaert at al. (2020). This has the advantage of measuring risk aversion using a structural model specifically designed to separate the price of

risk (or risk aversion) from the quantity of risk. However, inference about this separation may, of course, be contaminated by any model mis-specification.

First, we construct a largely statistical RORO index in a manner similar to that described in Datta et al (2017). Our RORO index comprises the z-score of the first principal component of daily changes in several standardized asset market variables. We normalize components such that positive changes imply risk-off behavior. Then, before taking the first principal component, we scale these normalized changes by their respective historical standard deviations.

Our first measure incorporates several series. To capture changes related to credit risk, we use the change in the ICE BofA BBB Corporate Index Option-Adjusted Spread for the 
United States and for the Euro Area, along with Moody's BAA corporate bond yield relative to 10-year Treasuries. To capture changes in risk aversion emanating from advanced economy equity markets, we use the additive inverse of daily total returns on the S\&P 500, STOXX 50 and MSCI Advanced Economies Index, along with associated changes in option implied volatilities from the VIX and the VSTOXX. To account for changes to funding liquidity, we include the daily average change in the G-spread on 2-, 5-, and 10-year Treasuries, along with changes in in the TED spread, the 3-month LIBOR-OIS spread, and the bid-ask spread on 3month Treasuries. Finally, we include growth in the trade-weighted U.S. Dollar Index against advanced foreign economies and the change in the price of gold. Figure 1 displays the time series and histogram of the headline measure.

To shed light on different components of risk or risk aversion, we also construct four sub-indices. These groupings, chosen to maximize the total explained variation of the components, fall into the four categories above: (1) spreads (credit risk), (2) advanced economy equity returns and implied volatility, (3) funding liquidity, and (4) currency and gold. As in the headline index, the subindices comprise the first principal component of the normalized series. Table 1.1 displays summary statistics for the headline measure and subindices. Since they are expressed as z-scores, we omit their means and standard deviations from the table.

Defining a risk measure comprising multiple sources of risk confers several advantages. First, agglomerating multiple sources of risk allows us to abstract from any one source of riskoff behavior in our baseline analysis. Elevating any particular asset price in the measurement of risk sentiment hazards the possibility that the relationship between the measure-asset and the risk-affected-asset of interest arises from a particular set of market participants, the actions of whom may not be generalizable across time and across assets. The group of market participants who take out, for example, S\&P 500 options to hedge against U.S. equity volatility have characteristics that may not extend equally to all other risk assets we might want to measure in the face of a risk-off shock. Second, our multivariate measure of risk-on/risk-off further permits the decomposition of baseline results into underlying drivers, offering insights into the source of a given risk-on or risk-off event, which itself may differentially drive emerging market capital flows and returns. Third, our measure recognizes sources outside of the United States which may drive risk-on/risk-off changes. Finally, because we measure the relationship 
of our index to assets in emerging markets, we can appeal to the small open economy character of the recipient markets to strengthen the plausibility of the index's exogeneity to local market fundamentals.

In recognition that the statistical approach used it deriving our first measure does not structurally distinguish the price of risk (risk aversion) from the amount of risk (economic uncertainty), we also turn to the method employed in Bekaert, Engstrom, and Xu (2020; BEX) for our second model-based RORO measure. Employing a wide set of macro and financial market data, BEX build on the family of habit-based asset pricing models (see, for example, Campbell and Cochrane (1999)) to separately identify variation in risk and risk aversion. We collect their daily measures of each, using variation in risk aversion as our second RORO measure 6

We present our first measure in Figure 1 (panels a and b), along with our second measure based on the model-implied dis-aggregation into changes in risk aversion (our second RORO measure in panel c) and risk (d). Both RORO measures exhibit (risk-off) skewness, excess kurtosis, and time varying volatility (see, also Table 1.1. Further, both measures show large spikes during the global financial, the European debt, and the COVID-19 crises.

\subsection{Capital Flows and Returns}

In order to obtain a multilateral, high frequency proxy of capital flows into and out of emerging markets, we use the country flows dataset from EPFR Global. EPFR Global publishes weekly portfolio investment flows by more than 14,000 equity funds and more than 7,000 bond funds, with more than USD 8 trillion of capital under management. The Country Flows dataset combines EPFR's Fund Flow and Country Weightings data to track the flow of money into world equity and bond markets. While fund flow data reports the amount of cash flowing into and out investment funds, the country weightings report tracks fund manager allocations to each of the various markets in which they invest. Combining country allocations with fund flows produces aggregate fund flows into and out of emerging markets (see Jotikasthira, Lundblad, and Ramadorai (2012)). Because the country flows comprise the sum of fund-level aggregate re-allocations, they come cleansed of valuation effects and therefore represent real

\footnotetext{
${ }^{6}$ Thanks to Nancy Xu for making these data available. https://www.nancyxu.net/risk-aversion-index
} 
quantities.

To measure returns on emerging market portfolio assets, we collect daily total returns from a number of well-known indices. Individual country returns on USD and local currency bonds come from J.P. Morgan's Emerging Market Bond Index (EMBI) and the Bloomberg Barclay's Local Bond Index, while we measure country-level equity returns using the Morgan Stanley Capital International (MSCI) local currency and USD indices. Figure 2 and Table 1.2 display the times series and summary statistics for return and flow measures.

Reflecting the availability of EPFR data, the sample runs from January 7, 2004 to Apr. 15, 2020.7 The sample of countries comprises emerging markets appearing in each of the flow and return data sets. Of these, we include countries with widespread recognition as emerging market economies $]^{8}$ The final set of countries includes Argentina, Brazil, Chile, Colombia, Czech Republic, Egypt, Hungary, India, Indonesia, Malaysia, Mexico, Pakistan, Peru, the Philippines, Poland, Qatar, Russia, South Africa, Taiwan, Thailand, Turkey, and the United Arab Emirates 9

\subsubsection{Control variables}

The literature on patterns of international capital flows separates determinants into common, global "push" factors associated with external shocks, and "pull" country-specific factors. Our control variables include both "push" and "pull" variables suggested by the literature on capital flows.

Following the literature on capital flow determinants (see, for example, Calvo, Leiderman, and Reinhart 1993; Fratzscher 2012; Fratzscher, Lo Duca, and Straub 2014; Passari and Rey 2015; Milesi Ferretti and Tille 2011; Broner et al. 2013; Forbes and Warnock 2012), the capital flow and return regressions include a measure of advanced market returns (obtained from Kenneth French's website), the monetary policy stance of advanced economies as measured by the shadow rate, and the advanced economy real GDP growth. ${ }^{10}$ We use year fixed effect

\footnotetext{
${ }^{7}$ The exception is local currency bond returns, which only become available in 2008.

${ }^{8}$ We exclude China due to its unique characteristics, including its size relative to other emerging market economies and measurement issues.

${ }^{9}$ EM classifications considered include the IMF, BRICS + Next 11, FTSE, MSCI, S\&P, EMBI, Dow Jones, Russell, Columbia University EMPG and BBVA.

${ }^{10}$ All advanced economy variables comprise a USD real GDP-weighted average of the United States, the UK, the euro area and Japan.
} 
control for global conditions more broadly, as well as a lag of the left-hand-side variable to account for the autocorrelation introduced by scaling over lagged positions. Time fixed effects account both for slow moving business cycles and structural changes in the market for ETFs and mutual funds.

Country-specific (pull factor) controls (see, for example, Ahmed and Zlate 2014; Forbes and Warnock 2012; Fratzscher 2012; Fratzscher, Lo Duca, and Straub 2013; Eichengreen and Gupta 2014; Moore et al. 2013; Chen, Mancini Griffoli, and Sahay 2014) include local policy rates, average real GDP growth in the previous eight quarters, and the broad real effective exchange rate (REER). To control for the influence of local macroeconomic news in the intervening week or day, we include the Citigroup Economic Surprise Index (CESI) for emerging markets. The CESI tracks how economic data compare to expectations, rising when economic data exceed economists' consensus forecasts and falling when data come in below forecast estimates 11

With the exception of emerging market news surprises, all control variables enter with a lag to rule out simultaneity $\mathbb{1 2}^{12}$ Both sets of controls affect capital flows and returns, but also likely react directly to changes in risk sentiment. In fact, our advanced economy push variables not only react to risk-on/risk-off shocks but likely also drive them. All daily variables enter as the weekly moving average leading up to the week's EPFR reporting date; thus, lagged variables consist of the weekly moving average ending on the date one week before the report of the measured flow.

\footnotetext{
${ }^{11}$ Indices are defined as weighted historical standard deviations of data surprises (actual releases vs. Bloomberg survey median) and are calculated daily in a rolling three-month window. The weights of economic indicators are derived from relative high-frequency spot FX impacts of one standard deviation data surprises. The indices also employ a time decay function to replicate the limited memory of markets.

${ }^{12}$ While news surprises likely drive capital flows and returns, it is unlikely that the risk shock drives news surprises or vice versa on any given date.
} 


\section{Results}

\subsection{Baseline Specification}

With risk indicators in hand, we regress weekly EPFR country-level flows and daily returns onto our risk appetite measures using the panel quantile regression approach of Machado and Santos Silva (2019) with country and time fixed effects, controlling for the "push" and "pull" factors described previously. Country level flows enter as a percent of the previous week's allocation, while total returns are expressed as a daily percentage change. As stated in the data description, in the EPFR flow regressions, changes in the risk measures are aggregated by a moving average.

$$
\begin{aligned}
R_{i t}^{(q)} & =\alpha_{i}^{(q)}+\delta_{t}^{(q)}+\beta_{i}^{(q)} R A_{t}+\gamma_{1}^{(q)} P U S H_{t}^{R}+\gamma_{2}^{(q)} P U L L_{i t}^{R}+\epsilon_{i, t} \\
k_{i t}^{(q)} & =\alpha_{i}^{(q)}+\delta_{t}^{(q)}+\rho k_{i t-1}^{(q)}+\beta_{i}^{(q)} R A_{t}+\gamma_{1}^{(q)} P U S H_{t}^{k}+\gamma_{2}^{(q)} P U L L_{i t}^{k}+\epsilon_{i, t}
\end{aligned}
$$

where $k_{i t}^{(q)}=\left(\frac{K_{i t}}{H_{i t-1}} * 100\right) . R_{i t}$ is the EMBI, LC Bond index, MSCI LC or MSCI USD daily total return. $R A_{t}$ is one of (i) the RORO Index or (ii) the risk/risk aversion measures from Bekaert et al (2020) ${ }^{13} k_{i t}$ is either equity or debt flows $\left(K_{i t}\right)$ scaled by holdings of the same, $H_{i t-1}$. We cluster bootstrapped standard errors by country to account for serially correlated error terms.

In general, risk-on, risk-off shocks have important implications not only for the median of emerging market flows and returns, but also for the tails of the distribution. In each case, a risk-off shock decreases flows and returns across the distribution. Further, in nearly every case we consider, the "worst" realizations (in the left tail) change more than the median realization, and the "best" (right tail) realizations change less than the median, lengthening the tails of the distribution $\left(\left|\beta^{(.05)}\right|>\left|\beta^{(.5)}\right|>\left|\beta^{(.95)}\right|\right)$. We summarize the results in Figures 3 a -4d. while Tables $2 \mathrm{a}-3.2 \mathrm{~d}$ isolate the risk-off regression coefficients for each case. As a reminder, each regression includes controls and various fixed effects; full results with all control variable coefficients are available in the Internet Appendix (Tables 4 - 6).

\footnotetext{
${ }^{13}$ In order to better understand the role for the various subcomponents that constitute our first RORO measure, we also consider a version of the panel quantile regression where $R i s k_{t}$ is a vector of the constituent subindices.
} 


\subsection{Risk-off Shocks and RORO}

First, we consider the case where we measure risk off shocks, $R A_{t}$, using our statistical RORO index. Figure 3a summarizes the impact of a one standard deviation risk-off shock (measured in this way) on the distribution of our EPFR flow measures and offers an object lesson in the importance of measuring the impact across the distribution. While the risk-off shock affects the median of the distribution in a similar manner across asset classes, the tails behave differently. We observe that the risk-off shock decreases bond outflow realizations in the left tail more than it decreases the median realization, and in turn decreases the highest inflow realizations less then the median. The net result is a leftward shift in the distribution, with a lengthening of the tails. Notably, as we will see in a later exercise, the lengthening in the left tail causes "large" outflow realizations in the unconditional distribution to appear more common in the post-shock distribution. Second, the equity flow distribution also shifts to the left in the face of a risk-off shock; however, the largest outflow realizations change less than the median, while the largest inflow realizations change more than the median. The net result is a leftward shift in the distribution, with a modest shortening of the tails. This is an important exception to the more general findings.

Figure $3 \mathrm{~b}$ summarizes the the impact of a one standard deviation risk-off shock ( on the distribution of fixed income and equity returns. Across all return types, a risk-off shock shifts the distribution to the left and lengthens the tails, worsening the most negative return realizations more than the median. The magnitude and dispersion of the impact, however, differs between fixed income and equity, and between local currency and USD denominated indices. In particular, a risk-off shock impacts the total return on the equity indices at a rate more than five times the impact on fixed income returns. Within each asset class, dollar returns react more than local currency returns. Fixed income bears this relationship out strikingly, decreasing three to six times the rate of the local currency index in the face of the risk off shock ${ }^{14}$ MSCI USD total returns decrease 28 - 32\% more than the local currency equity returns in the face of a risk-off shock.

\footnotetext{
${ }^{14}$ While the impact on the local currency index is statistically insignificant, the comparison is still a useful one given that USD denominated bonds do react in a statistically significant manner.
} 


\subsection{Risk-off Shocks and BEX (2020)}

Given the aforementioned limitations of measuring risk-off shocks with a statistical measure, we next turn to a structural decomposition that facilitates a separation of risk aversion from physical risk. Figures $4 a$ and $4 b$ summarize the changes in the capital flow distributions when we employ Bekaert et al's (2020) risk aversion. Specifically, $R A_{t}$ is measured as the change in the risk aversion component from that model (note that we also include the model's implication for variation in the quantity of risk as a control). This approach reveals an interesting pattern underlying the heterogeneous reactions of the equity and fixed income distributions.

The impact of risk aversion (and risk itself) on the distribution of fixed income flows follows the same pattern as with our first RORO measure; that is, a risk-off shock measured in this alternative way again shifts the distribution to the left and lengthens the tails relative to the median. Interestingly, variation in the quantity of risk has a larger impact across the distribution and puts more weight in the left tail compared to risk aversion itself; this is the case across asset classes. Where bonds and equity funds (and returns) differ in their reactions in the dispersive impact of risk aversion shocks. This distinction offers a window into the workings of our statistical measure and enables us to consider risk measurement and co-movement more generally.

In particular, equity flows react to variation in both risk and risk aversion in a manner which sheds light on the distribution's reaction to our first statistical risk-off measures. In the face of a physical risk shock, the distribution of equity flows reacts in step with the distribution of bond flows in that we observe a leftward shift, with tails lengthening relative to the median. In contrast, a risk-off shock (the change in risk aversion) causes the equity flow distribution to behave as it does with our first RORO measure, with the range of the distribution shrinking as it shifts left. This suggests that the distributional reaction that we observe with a RORO shock based on our first measure emanates from a sensitivity to changing risk aversion, which causes a convergence of realizations relative to the unconditional distribution (and to the distribution conditional on risk-off shocks to physical risk).

Figures $4 \mathrm{c}$ and $4 \mathrm{~d}$ depict the changes in the return distributions when we replace our statistical measures of risk with Bekaert et al's (2020) risk and risk aversion indices. Here we ob- 
serve that a risk-off shock (to risk aversion), as well as a shock to physical risk, shift the distribution of returns to the left. However, changes in the level of risk dramatically lengthen the tails of the return distribution, while changes in risk aversion shrink the tails. From the perspective of understanding the drivers of tail risk in particular, it is notable that in both asset classes, a risk-off shock to physical risk or uncertainty weighs heavily on negative tail events in a manner which would clearly be masked by the conditional mean and variance.

The relative impact of the two components on returns differs between asset classes. Between the two, risk aversion plays a larger role in driving equity returns relative to the influence of risk, and the opposite holds (albeit less systematically) for fixed income returns. Given the relative magnitude of the two effects, the joint impact of a combined and equal-magnitude shock in each of the components would net out to a leftward shift and a lengthening in the tails.

\subsection{Risk-on Risk-off Constituents}

Figures $5 \mathrm{a}$ and $5 \mathrm{~b}$ provide a more nuanced picture of our RORO index using a nested panel regression that includes the constituent sub-components ${ }^{15}$ Including the constituent measures together suggests that much of the baseline's "shifting" impetus emanates in large part from corporate spreads for both equity and bond funds. The nested model also reveals funding liquidity as a prime source of the bond funds" "tails-out" behavior relative to equity funds. Interestingly, once we include credit risk in the model with the advanced economy equity and volatility factor, the latter evinces less impact on equity funds and even moves median-plus realizations to the right, reflecting the risk-off behavior of rotating out of equities and into bonds. We see this reflected in equity funds' reaction to Bekaert et al's (2020) measure of risk aversion.

Figure $5 \mathrm{c}$ again shows how emerging market returns react to the various elements of our RORO index, considered together. Here, advanced economy returns and volatilities, along with corporate spreads, drive the much of the overall magnitude of the distributional shift. This is more so the case for equity returns compared to fixed income returns, reflecting comovements in global equity returns documented elsewhere in the literature. However, asset

\footnotetext{
${ }^{15}$ The full regression results for each case are available in the Internet Appendix (Table 6).
} 
classes and currencies all share increased distributional dispersion emanating primarily from credit risk as measured by corporate spreads. In the case of equity returns, the "tails-out" impetus from a risk-off credit risk shock counteracts the "tails-in" impetus from advanced economy equity return shocks. Here again we see a mapping to our chosen structural measuresFigure $4 \mathrm{~d}$ suggests that risk shocks lengthen the tails enough to outweigh risk aversion's distributional compression. The net result of both the structural and statistical measures, then, is to increase the incidence of extreme realizations.

Comparatively smaller reactions stem from the other two component indices. Currency risk acts as a shift factor which, while always smaller in size than returns or spreads, contributes more to risk-off reactions in dollar denominated returns. Finally, across asset classes and currency denominations, the impact of funding liquidity barely registers, contributing little in the way of shifts or dispersion and almost always statistically insignificant.

\subsection{Flight to Safety}

A question that naturally arises when examining the relationship between risk appetite and the allocation to or pricing of risky assets relates to the complementary implication for socalled "safe" assets. A safe asset is a simple debt instrument that is expected to preserve its value across various states of the world including adverse, possibly systemic events. Under this definition, the categorization of what assets exactly are to be considered "safe" remains a point of discussion (see Gorton (2016) and Caballero, Farhi, and Gourinchas (2017) as examples among many, many others). However, U.S. Treasury bonds are generally considered to be safe under this definition, and we will focus here.

Accordingly, we test the degree to which our various risk aversion measures reflect a flight-to-safety by repeating the above exercise replacing EPFR emerging market (risky asset) flows with the growth rate of assets held in U.S. money market mutual funds. These data are published by the Investment Company Institute, which reports money market fund assets to the Federal Reserve each week. To isolate safe assets, we focus on the subset of funds that invest in U.S. government debt.

In this exercise, we retain most of our global "push" variables: advanced economy market returns, advanced economy GDP growth, and the average advanced economy monetary 
stance as measured by the shadow rate. We also retain year fixed effects. We run the following regression:

$$
g_{t}^{(q)}=\alpha^{(q)}+\delta_{t}^{(q)}+\beta^{(q)} R A_{t}+\gamma_{1}^{(q)} P U S H_{t}^{k}+\epsilon_{t}
$$

Where $g_{t}^{(q)}$ is the weekly growth rate of government money market assets in quantile $q$, and $R A_{t}$, exactly as above, is either our RORO index or the risk/risk aversion decomposition from Bekaert et al. (2020).

Table 4 summarizes the results. In columns (1)-(4), we observe that risk-off RORO shocks drive inflows into Treasury-focused money market funds across the distribution of fund flows; this appear to be particularly true for the right tail, where larger inflows becomes more likely in the face of a risk-off shock. In columns (5)-(8), we show complementary results for the BEX decomposition. A shock to physical risk has some positive effect on government money market fund flows (although this effect is not consistent across the distribution). Risk aversion (risk-off) shocks drive the left tail of the distribution toward the median, but we do not observe statistically significant impacts elsewhere in the distribution. To examine these effects further, we separate these fund flows (in Internet Appendix Table 7) into two subsets of government money market funds, those available to institutions vs. those available to retail investors. We find that the largest effects documented in Table 4 are associated with institutional money market fund flows. Retail flows are considerably less sensitive to risk-off shocks. Taken together, we do detect across our various specifications some reaction to riskoff shocks in the allocation to safe assets in a manner that complements what we observe for risky assets.

\section{Quantitative Exercise: An Application to the COVID-19 Crisis}

The market turmoil surrounding the global transmission of COVID-19 in early 2020 generated movements in both emerging market portfolio assets and measures of risk that match or exceed the magnitude of other widely recognized risk-off events. Our approach allows us to quantify how the distribution of capital flow realizations changed in the face of COVID- 
19 shocks and how the sources of risk therein generated patterns distinct from other risk-off events. To quantify the impact of COVID-19 and other large risk-off periods, we undertake two exercises using fitted values from our analysis. First, we show counterfactual quantiles of the post-shock distribution of flows and compare them to the recent history of the data as follows. We define predicted capital flows $\hat{k}^{q}$ as

$$
\hat{k}^{q}=k^{q}+\hat{\beta}^{q} * \operatorname{shock} * H
$$

where $\hat{k}^{q}$ is the estimated flow calculated from fitted values, $k^{q}$ is the $q$ th percentile observed country flow per week in the data since Jan. 2020, $H$ is the average assets under management, and shock is the 10th percentile shock realization in the COVID era (3.1 units). Table 5 reveals the economic magnitudes underlying the parameter values reported in the results.

Starting with bond flows, in the face of a unit shock, the median reallocation is an outflow of \$14.09 million, compared to a pre-shock 2020 median weekly inflow of \$3.7 million. This size shock increases outflow realizations in the 5th quantile by $\$ 22$ million per week, compared to $\$ 17.8$ million per week at the median. Inflow realizations at the 95th quantile decrease by $\$ 14.8$ million. A one standard deviation shock, 3.1 units, increases outflow realization by $\$ 68.03$ million, compared to a change of $\$ 55.2$ million at the median and $\$ 43.5$ million at the 95th quantile. In the peak observation of the COVID-19 crisis, the index reached 11.56 standard deviations, suggesting that Q5, Q50 and Q95 would fall by \$256.7 million, \$205.9 million, and \$162.14 million respectively. A shock of this size pulls the tail realizations apart by $\$ 92$ million.

As aforementioned, equity flows show a shrinking of the tails in the event of a risk-off shock. After a one unit shock, the median reallocation is an outflow of $\$ 18.84$, compared to a pre-shock 2020 median outflow of $\$ 5.8$ million. This size shock increases outflow realizations in the 5th quantile by $\$ 16.28$ million per week, compared to $\$ 18.8$ million per week at the median. Inflow realizations at the 95th quantile decrease by $\$ 21.4$ million. A one standard deviation shock, 3.1 units, increases outflow realization by $\$ 50.5$ million, compared to a change of $\$ 58.4$ million at the median and $\$ 66.3$ million at the 95th quantile. In the peak observation of the COVID-19 crisis, the index reached 11.56 standard deviations, suggesting that Q5, Q50 
and Q95 would fall by $\$ 188.2$ million, $\$ 217.7$ million, and $\$ 247.3$ million respectively. A shock of this size pulls the tail realizations in by $\$ 59$ million. Under the peak shock, even the "best" realizations manifest as equity fund outflows.

Second, we fit a kernel density to the predicted values to visualize changes in the flow or return distribution from a 3-unit risk-off shock, displayed in Figure 7. We show 3-unit shocks because this magnitude represents the threshold of the 10th percentile among risk-off shocks in 2020. The fitted distribution of fixed income flows has longer tails and is more highly skewed toward outflows compared to the unconditional distribution (-.61 vs. -1.01). In terms of magnitude, in the face of a 3-unit shock, what would be a tail event in the unconditional distribution looks more like a 10th quantile shock, and therefore more probable. The post-shock median now falls in the bottom $25 \%$ of pre-shock realizations. The equity flow distribution appears unchanged in terms of skewness, although here as well the post-shock median falls in the bottom $25 \%$ of pre-shock realizations.

The return distributions show more dramatic changes still, although the skewness of the distributions show little change. What the unconditional equity distribution would label a tail outcome lay near the median in the post-shock distribution. While our RORO shock affects EMBI returns to a comparatively smaller degree, the pre-shock tail event still falls within the interquartile range of the unconditional distribution.

Figure 8 repeats this exercise for the subcomponents of Bekaert et al (2020). The conditional distributions attributed to each subcomponent in these figures represents the response of the distribution to a three standard deviation shock to one factor, controlling for the other. We see that, for bond flows, risk aversion and risk contribute in roughly equal measure to the increased mass of value under the left tail, while risk represents the greater force in pushing equity outcomes past the $5^{\text {th }}$ quantile of the unconditional equity flow distribution. In contrast, risk aversion plays a larger role in worsening negative return distributions, particularly in bond returns. 


\section{Conclusion and Future Directions}

Risk-on/risk-off shocks have important distributional implications for emerging market portfolio flows and returns. In particular, we find that the effects associated with the worst realizations are often disproportionately affected by risk-off shocks. Specifically, while there are some differences in the effects across bond vs. equity markets and flows vs. asset returns, the effects associated with the left tail are generally larger than that on the median realization. We conclude that the focus in the literature on measures of central tendency is incomplete.

A natural next question for our research agenda: do the implications of a RORO shock differ across recipient countries? Given that the mutual fund business exhibits significant variation in manager discretion, the heterogeneity question has two dimensions. The first is country-level heterogeneity, meaning are the effects of an external RORO shock disproportionately experienced across countries along important dimensions. Gelos et al. (2019) show that variation in recipient country economic policy and business fundamentals affect capital flows. In the context of our setting, the question arises whether recipient country conditions impact fund reallocation in the face of risk-off shocks. In particular, we want to be able to address the extent to which fund managers view emerging markets as a single asset class or whether country fundamentals matter for fund allocations.

An important caveat, however, is that the level of discretion fund managers possess varies considerably across fund type. Representing about half of the emerging market fund space towards the end of the sample, passive index funds and ETFs have very little manager discretion. As a consequence, passive index fund and ETF re-allocation in the face of a risk-off shock may induce elevated correlations among countries and minimize the effect of crosscountry heterogeneity. Actively managed mutual funds, however, enjoy considerable discre-

tion. Country fundamentals may be central to their allocation decision. Going forward, we will assess the complete effect of tail events on capital flows by closely examining the actual vehicles that investors use to access emerging markets. 


\section{References}

Adrian, T., Boyarchenko, N., \& Giannone, D. (2019). Vulnerable Growth. American Economic Review, 109(4), 1263-1289.

Avdjiev, S., Du, W., Koch, C., \& Shin, H. S. (2019). The Dollar, Bank Leverage, and Deviations from Covered Interest Parity. American Economic Review: Insights, 1(2), 193-208.

Bekaert, G., Engstrom, E. C., \& Xu, N. R. (2019). The time variation in risk appetite and uncertainty (Vol. No. 25673).

Bekaert, G., Harvey, C. R., \& Lundblad, C. (2005). Does financial liberalization spur growth? Journal of Financial economics, 77(1), 3-55.

Caballero, R. J., Farhi, E., \& Gourinchas, P.-O. (2017). The safe assets shortage conundrum. Journal of Economic Perspectives, 31(3), 29-46.

Calvo, G. A. (1998). Capital flows and capital-market crises: The simple economics of sudden stops. Journal of Applied Economics, 1, 35-54.

Chari, A., \& Henry, P. B. (2004). Risk sharing and asset prices: evidence from a natural experiment. The Journal of Finance, 59(3), 1295-1324.

Chari, A., \& Henry, P. B. (2008). Firm-specific information and the efficiency of investment. Journal of Financial Economics, 87(3), 636-655.

Chari, A., Stedman, K. D., \& Lundblad, C. (2020). Taper Tantrums: Quantitative Easing, its Aftermath and Emerging Market Capital Flows. Review of Financial Studies, Forthcoming.

Eguren-Martin, F., O’Neill, C., Sokol, A., \& von dem Berge, L. (2020). Capital flows-at-risk: Push, pull and the role of policy. Bank of England Staff Working Paper, No. 881.

Erik, B., Lombardi, M. J., Mihaljek, D., \& Shin, H. S. (2020). The Dollar, Bank Leverage, and Real Economic Activity: An Evolving Relationship. AEA Papers and Proceedings, 110, 529-534.

Forbes, K., \& Warnock, F. (2019). Capital flow waves—or ripples? extreme capital flow movements in an era of easy monetary and tight macroprudential policy. NBER Working Paper, No. 26851.

Forbes, K. J. (2020). Do Sounder Banks Make Calmer Waters? The Link between Bank Regulations and Capital Flow Waves. AEA Papers and Proceedings, 110, 516-522.

Forbes, K. J., \& Warnock, F. E. (2012). Capital flow waves: Surges, stops, flight, and retrenchment. Journal of International Economics, 88(2), 235-251.

Fratzscher, M. (2012). Capital flows, push versus pull factors and the global financial crisis. Journal of International Economics, 88(2), 341-356.

Gelos, G., Gornicka, L., Koepke, R., Sahay, R., \& Sgherri, S. (2019). Capital flows at risk: Taming the ebbs and flows.

Gorton, G. (2017). The history and economics of safe assets. Annual Review of Economics, 9, 547-586.

Gourinchas, P.-O., \& Obstfeld, M. (2012, January). Stories of the Twentieth Century for the Twenty-First. American Economic Journal: Macroeconomics, 4(1), 226-265. 
Henry, P. B. (2007). Capital account liberalization: Theory, evidence, and speculation. Journal of economic Literature, 45(4), 887-935.

Jotikasthira, C., Lundblad, C., \& Ramadorai, T. (2012). Asset fire sales and purchases and the international transmission of funding shocks. The Journal of Finance, 67(6), 2015-2050.

Machado, J. A., \& Silva, J. S. (2019). Quantiles via moments. Journal of Econometrics, 213(1), 145-173.

Mendoza, E. G., \& Terrones, M. E. (2008, May). An Anatomy Of Credit Booms: Evidence From Macro Aggregates And Micro Data (NBER Working Papers No. 14049). National Bureau of Economic Research, Inc. Retrieved from https://ideas.repec.org/p/nbr/nberwo/ 14049.html

Miranda-Agrippino, S., \& Helene, R. (2020). Us monetary policy and the global financial cycle. Review of Financial Studies, Forthcoming.

Miranda-Agrippino, S., \& Rey, H. (2020). The Global Financial Cycle after Lehman. AEA Papers and Proceedings, 110, 523-528.

Rey, H. (2013). Dilemma not trilemma: The global financial cycle and monetary policy independence. Federal Reserve Bank of Kansas City Economic Policy Symposium. 
Figure 1: Risk-on/Risk-off Measures

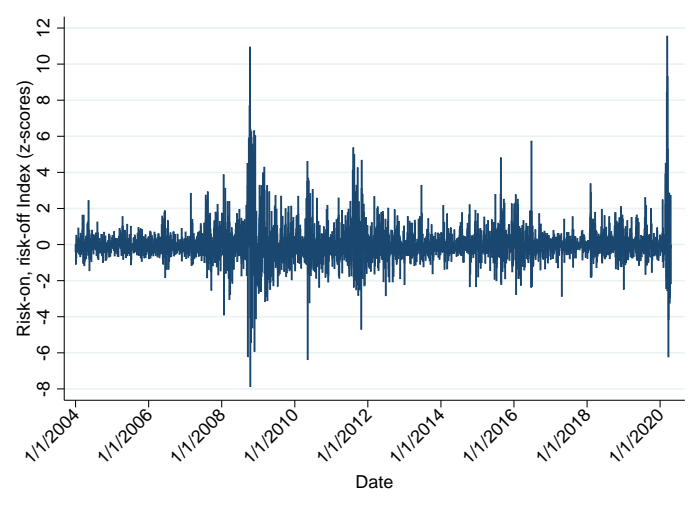

(a) Time series: RORO

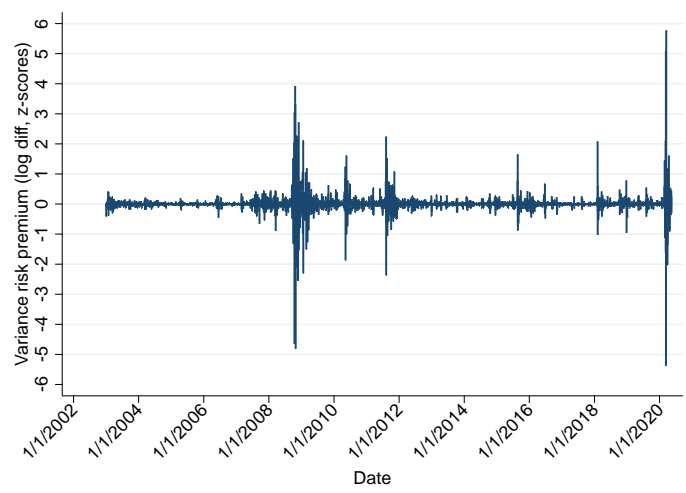

(c) Time Series (log difference): Risk Aversion (Bekaert et al 2020)

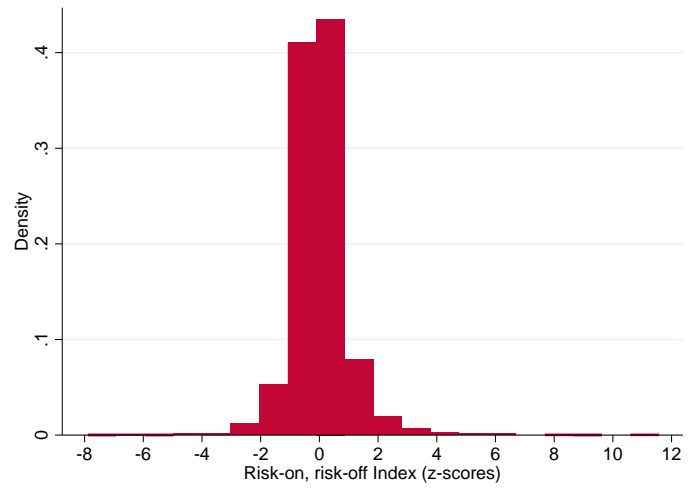

(b) Histogram: RORO

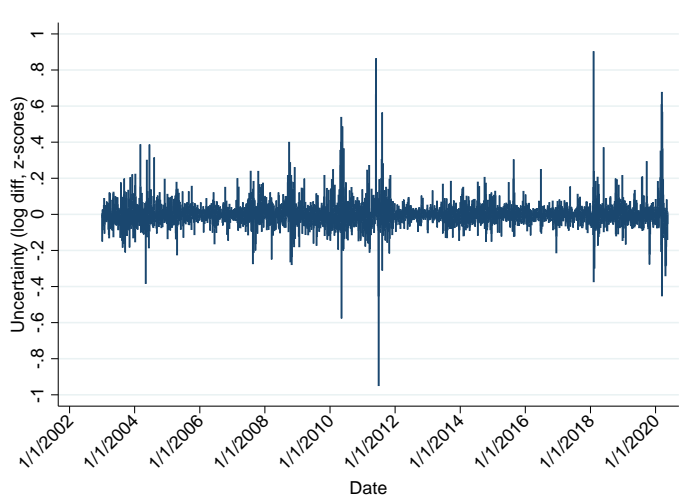

(d) Time Series (log difference): Risk (Bekaert et al 2020) 
Figure 2: Emerging Market Flows and Returns
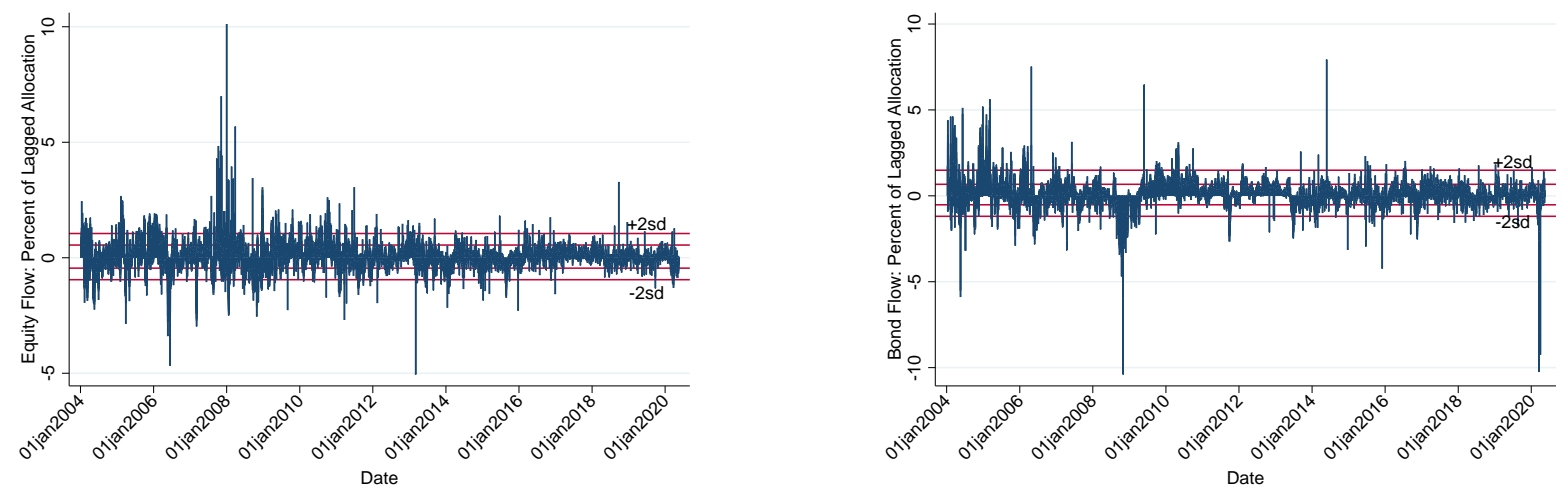

(a) EPFR Country Flows (\% of Lagged AUM)
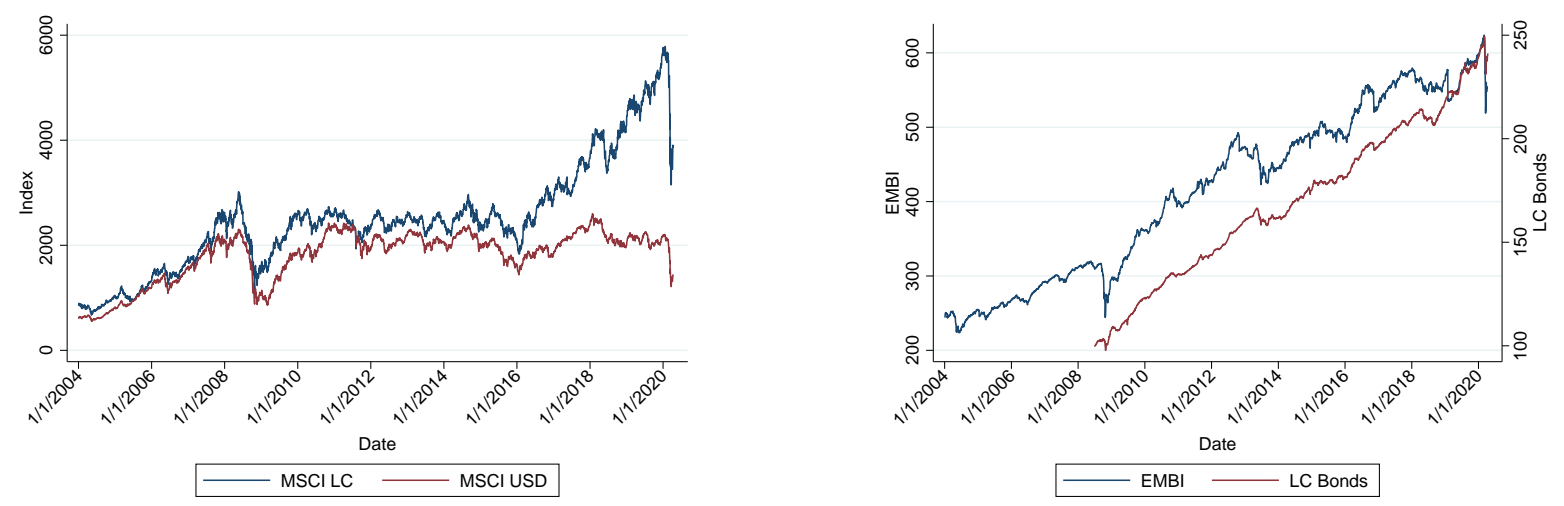

(b) Total Return Indices 

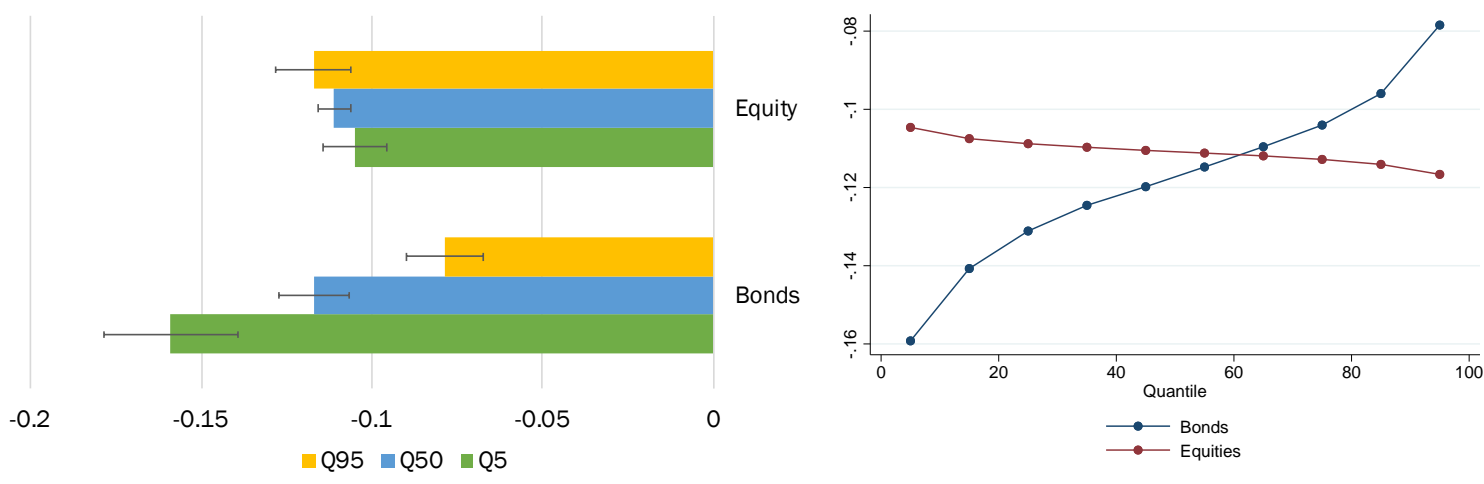

Figure 3a: A one standard deviation risk-off (RORO) shock \& the distribution of EPFR flows (\% of AUM)

Notes: This figure summarizes the impact of a one-standard deviation risk-off shock as measured by our RORO Index. Error bars represent $90 \%$ confidence intervals.
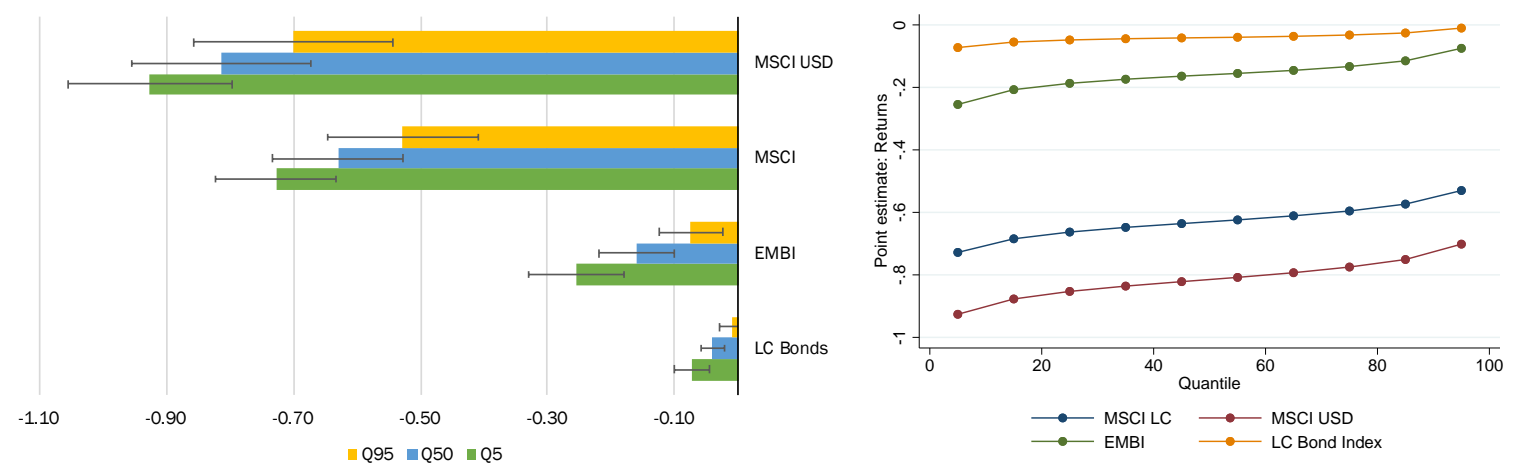

Figure 3b: Impact of a one standard deviation risk-off (RORO) shock on the distribution of returns

Notes: This figure summarizes the impact of a one-standard deviation risk-off shock as measured by our RORO Index. Error bars represent $90 \%$ confidence intervals. 

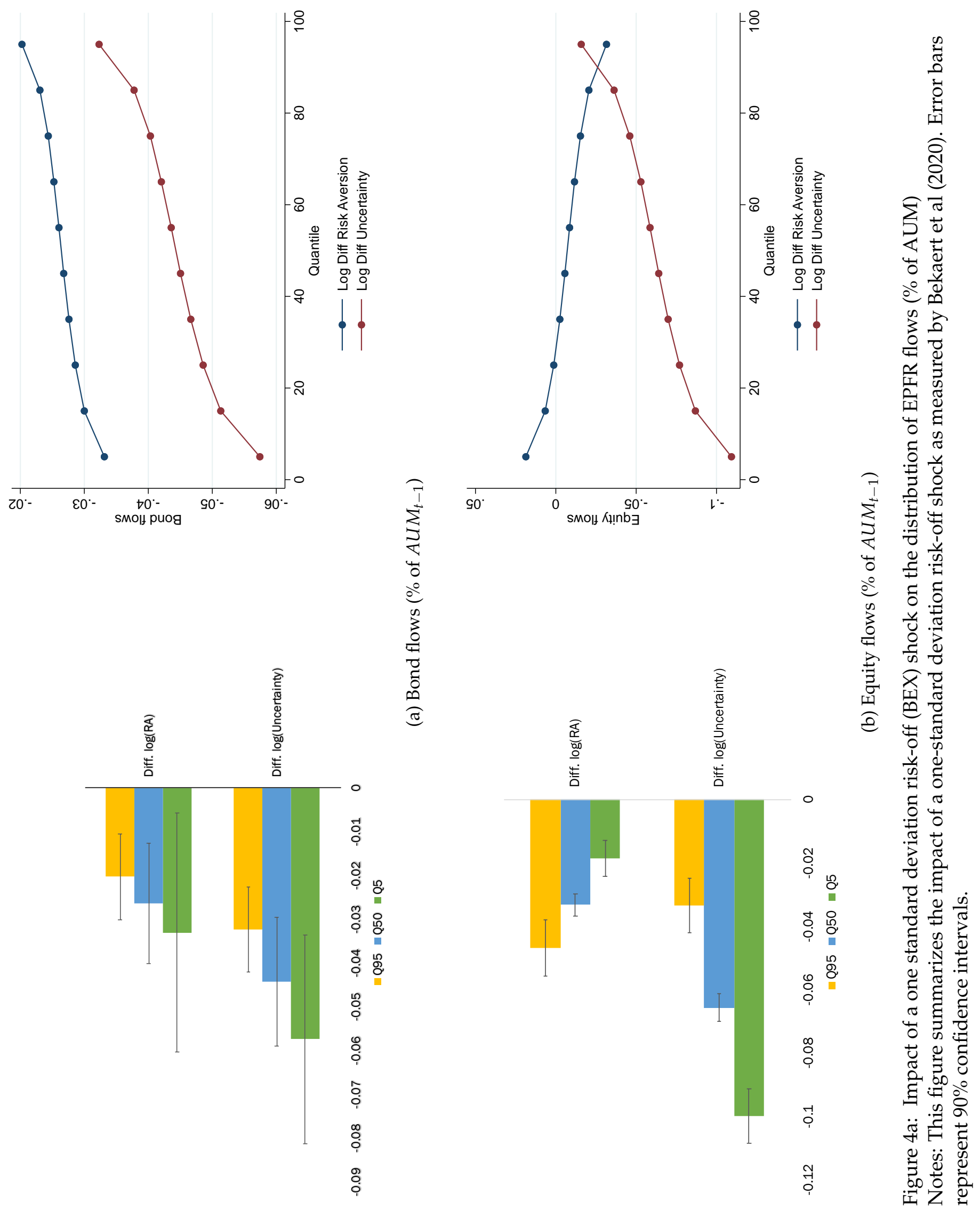


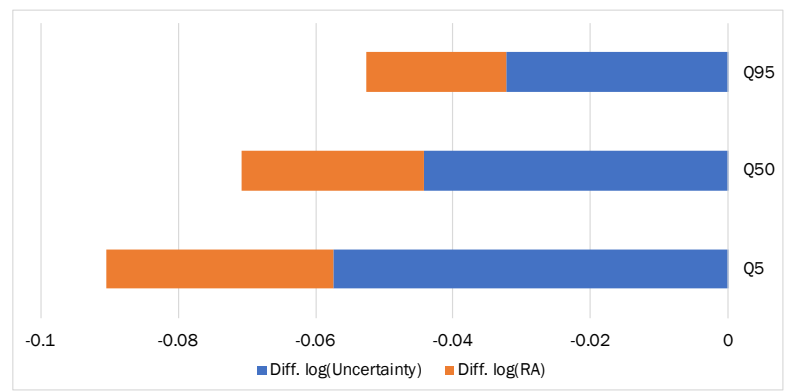

(a) Bonds

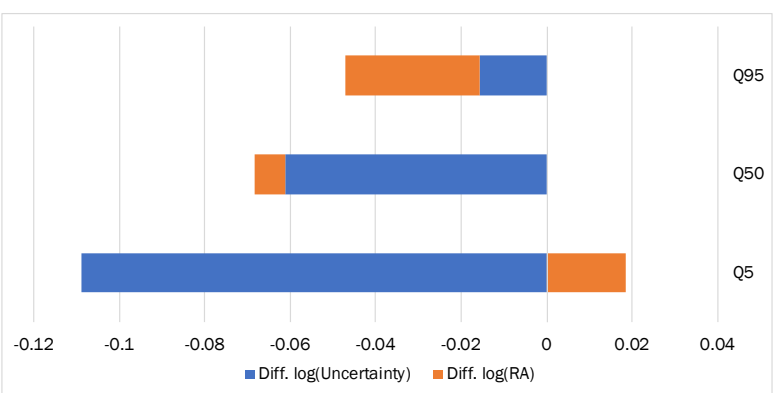

(b) Equity

Figure 4b: A one standard deviation constituent risk-off (BEX) shock \& the distribution of EPFR flows (\% of AUM)

Notes: This figure summarizes the impact of a one-standard deviation risk-off shock as measured by Bekaert et al (2020). 

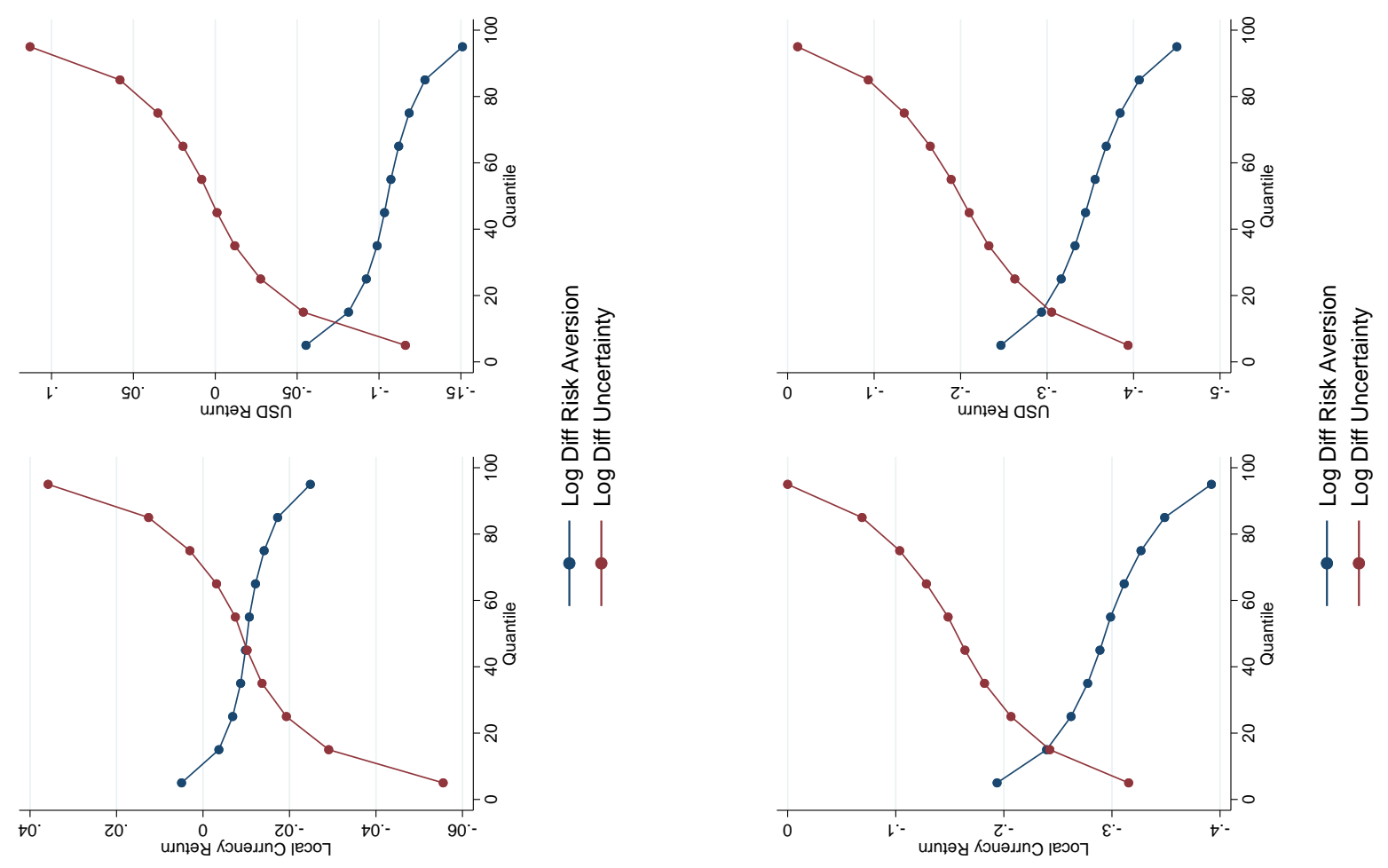

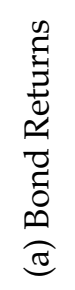
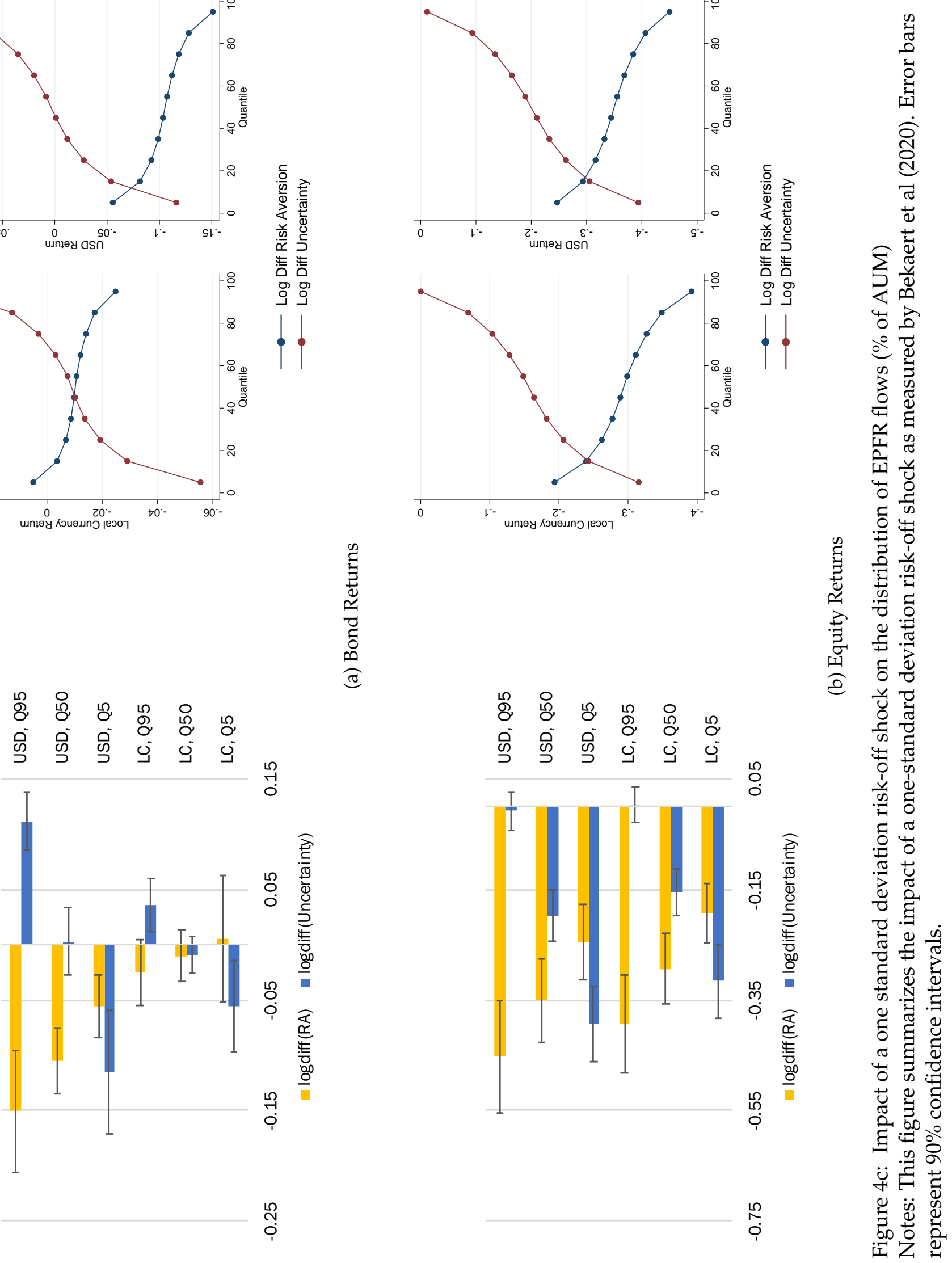


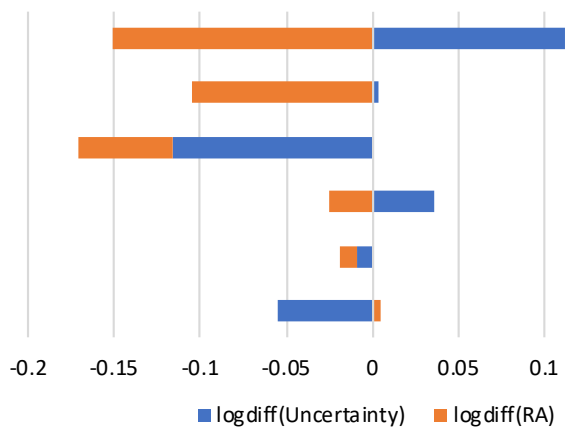

(a) Bonds

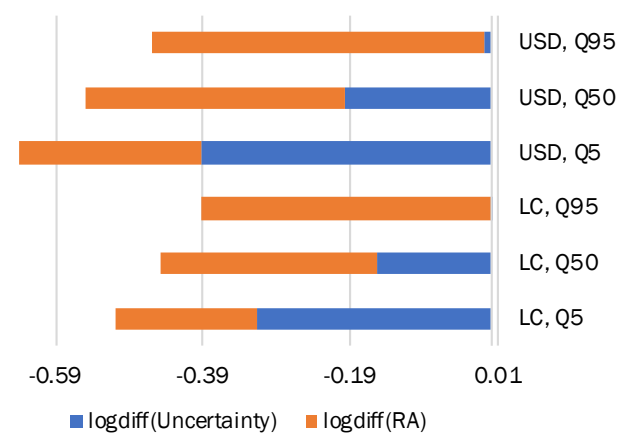

(b) Equity

Figure 4d: A one standard deviation constituent risk-off (BEX) shock \& the distribution of returns

Notes: This figure summarizes the impact of a one-standard deviation risk-off shock as measured by by Bekaert et al (2020). 

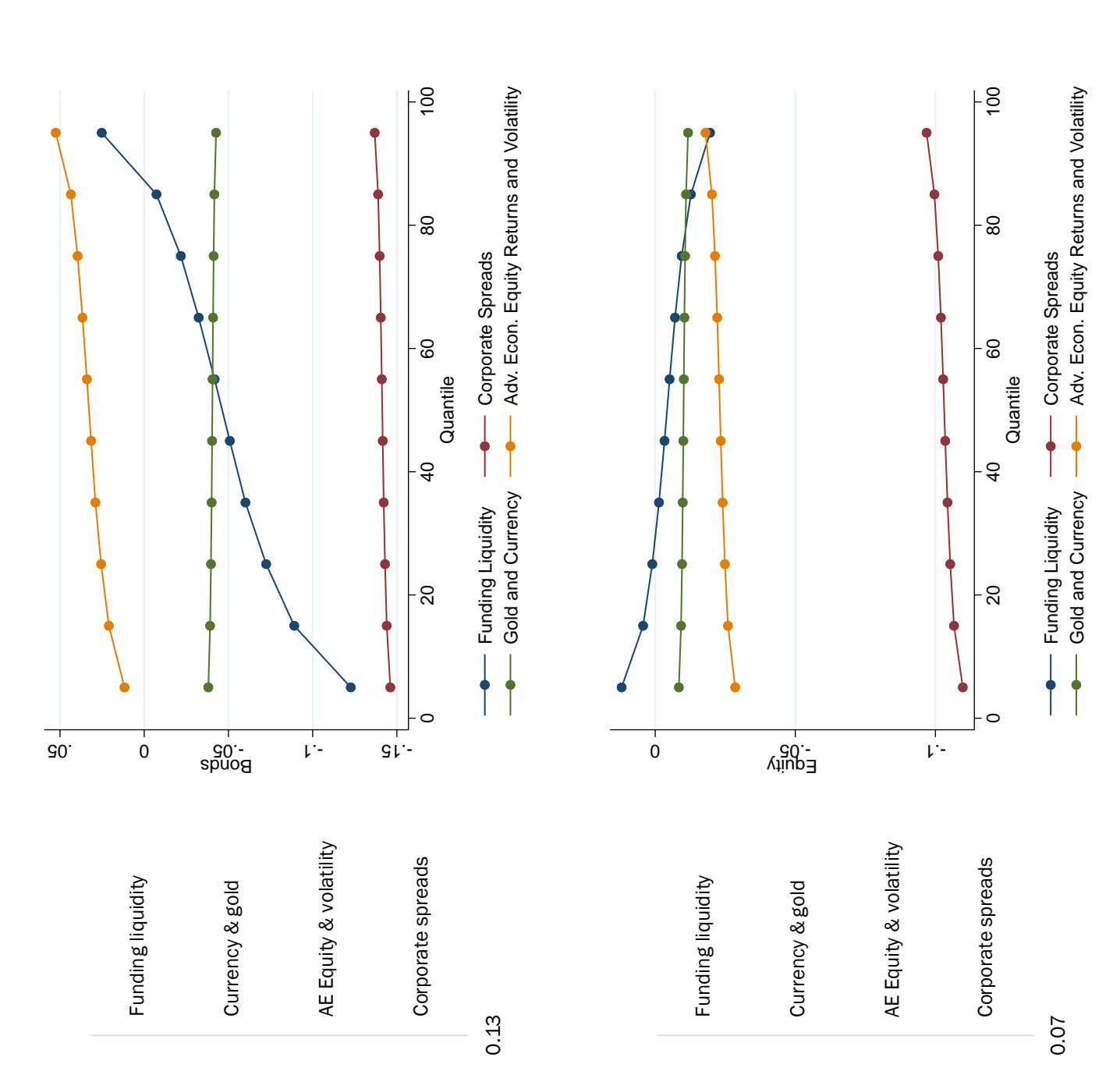

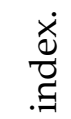
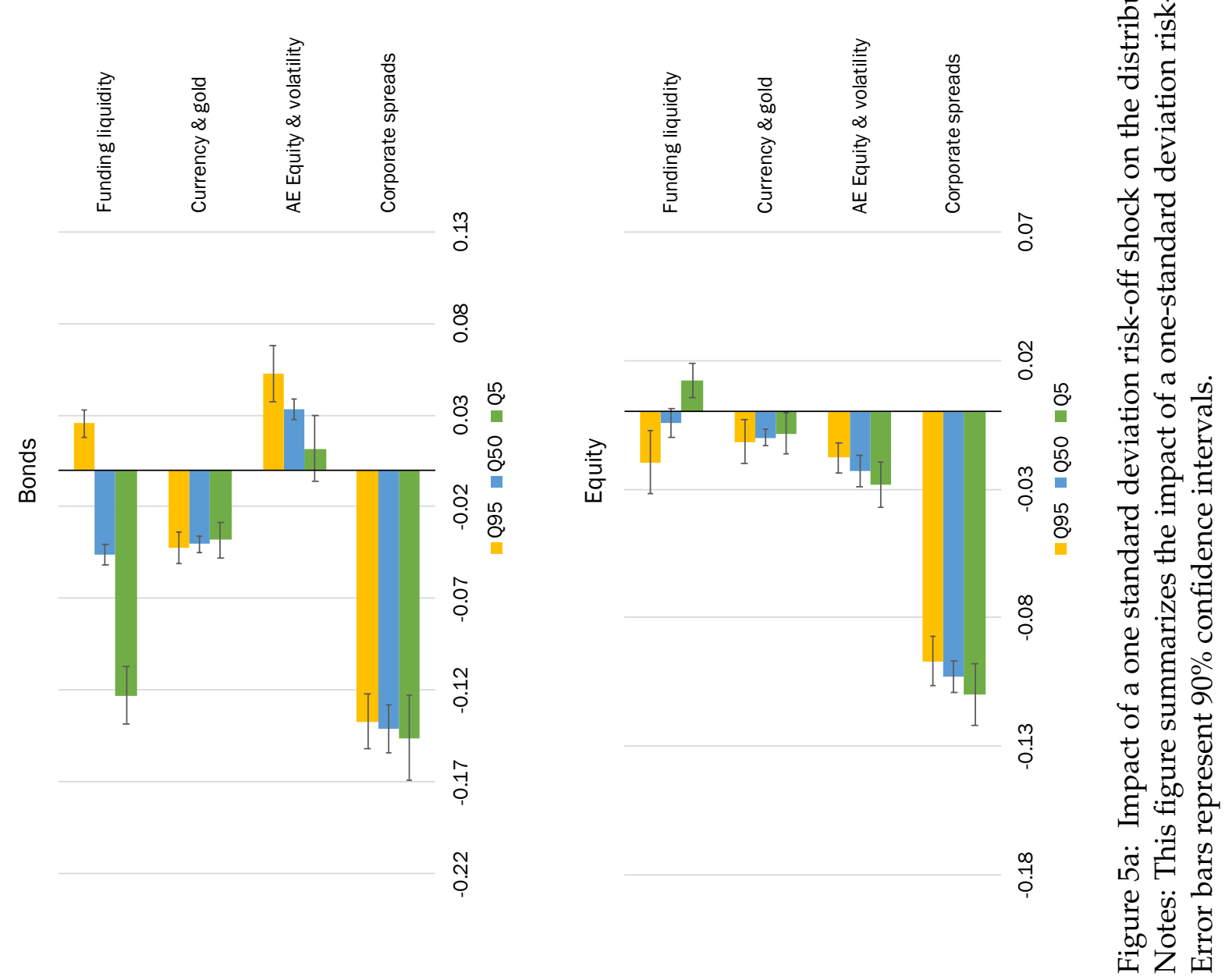


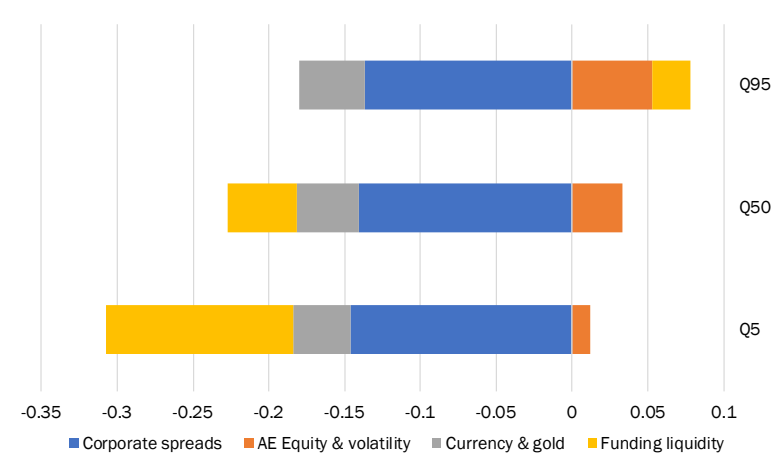

(a) Bonds

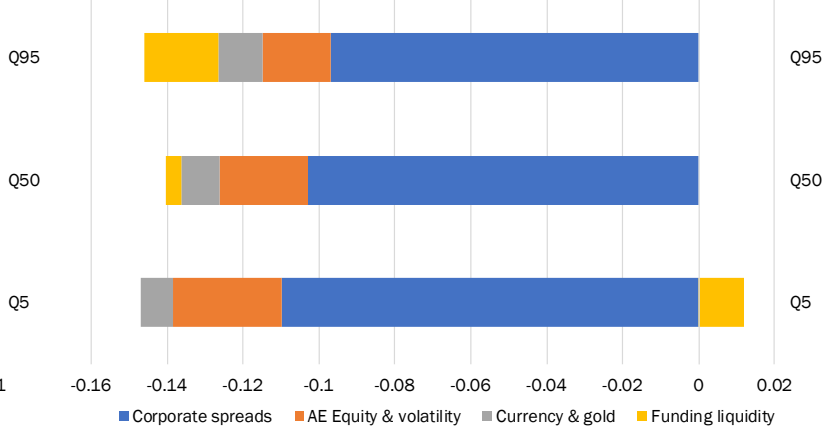

(b) Equity

Figure 5b: A one standard deviation constituent risk-off (RORO) shock \& the distribution of EPFR flows (\% of AUM)

Notes: This figure summarizes the impact of a one-standard deviation risk-off shock as measured by our RORO subindices. 

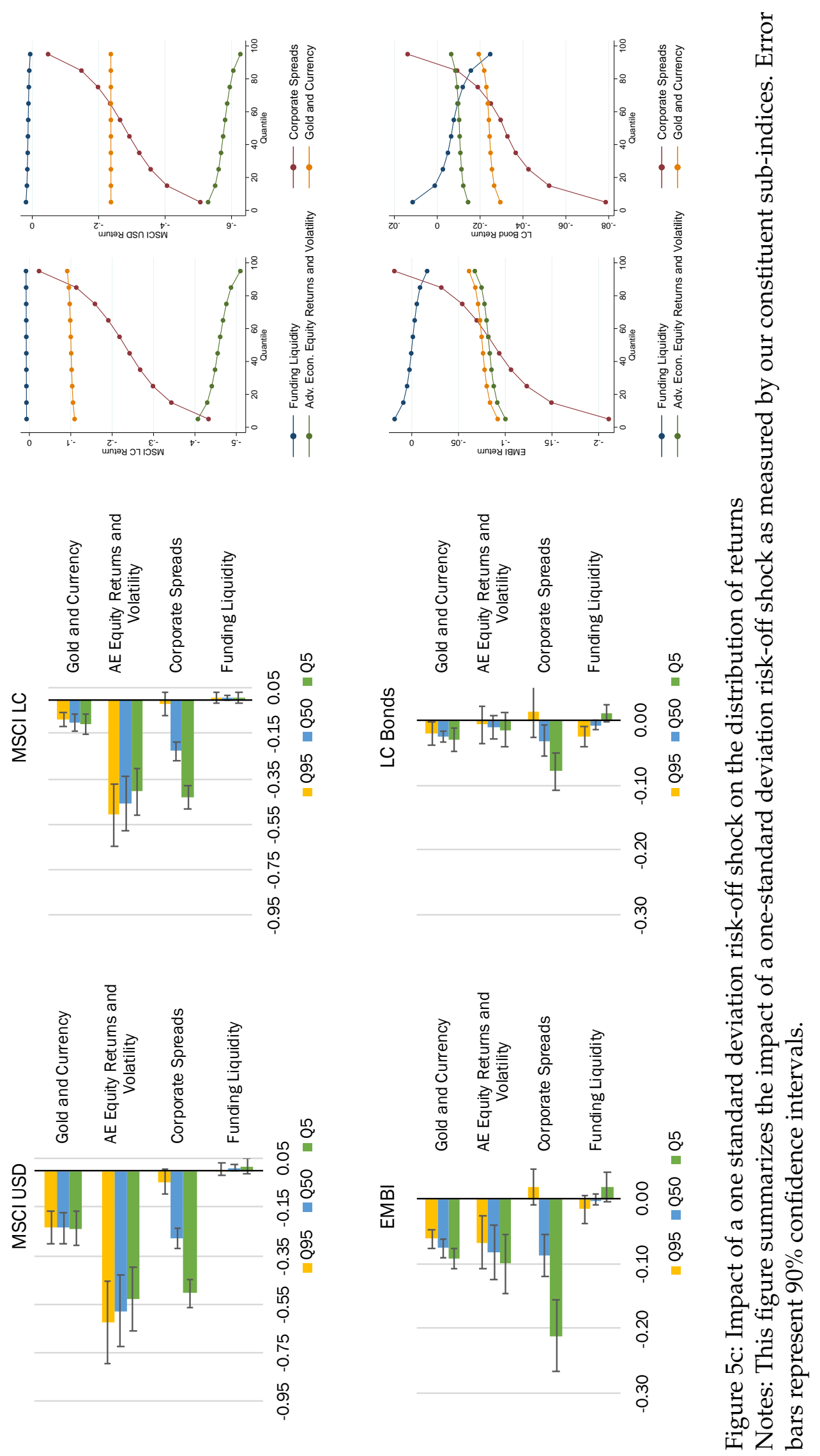


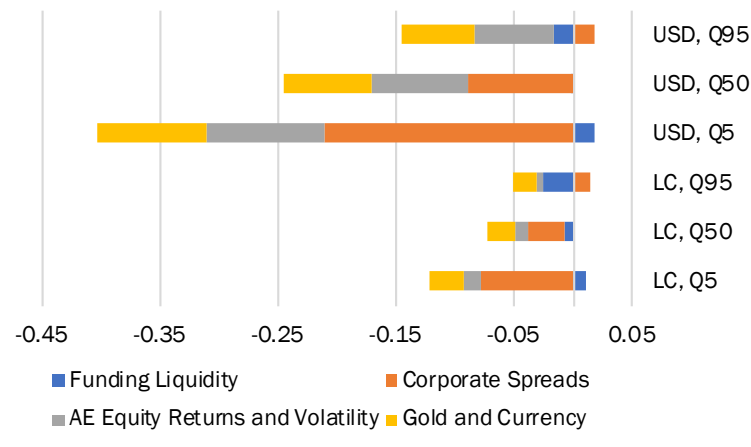

(a) Bonds

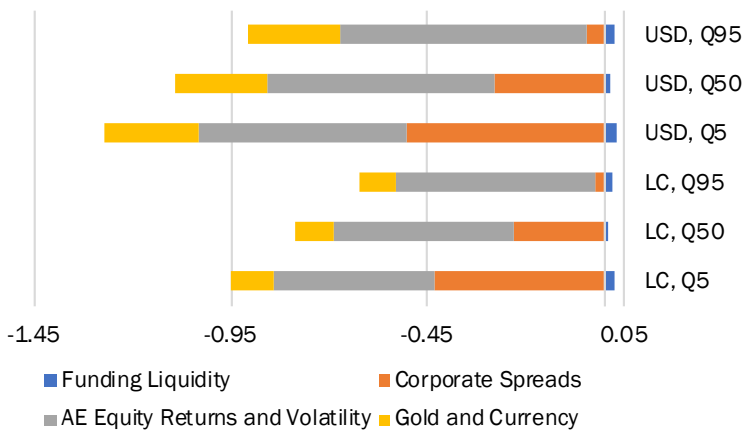

(b) Equity

Figure 5d: A one standard deviation constituent risk-off (RORO) shock \& the distribution of returns

Notes: This figure summarizes the impact of a one-standard deviation risk-off shock as measured by our RORO subindices. 
Figure 6: Emerging market capital flows and returns in recent risk-off episodes

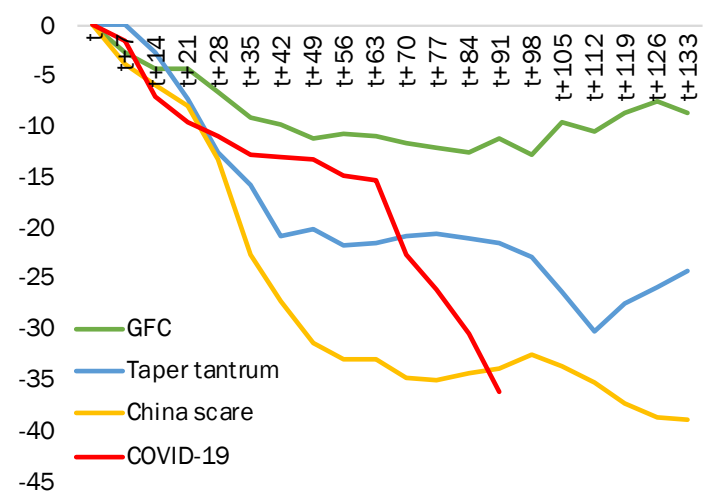

(a) Equity flows (USD Billions)

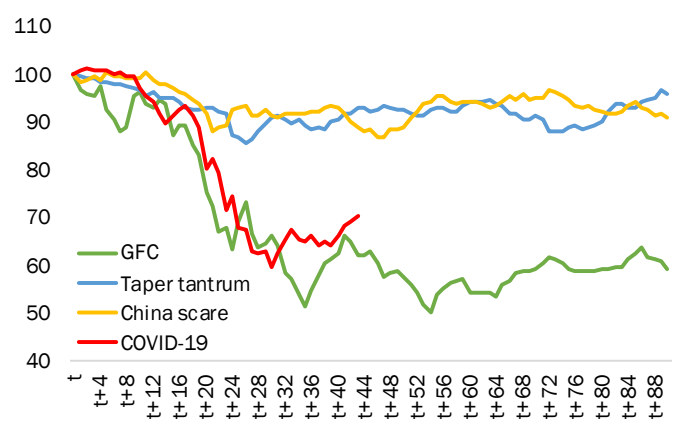

(c) MSCI USD

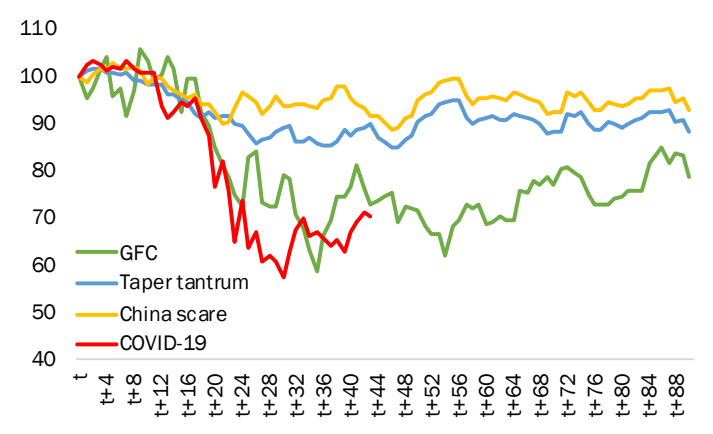

(e) MSCI LC

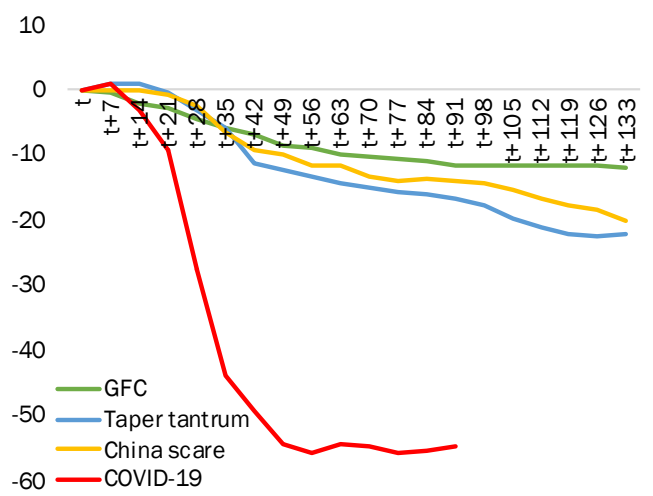

(b) Bond flows (USD Billions)

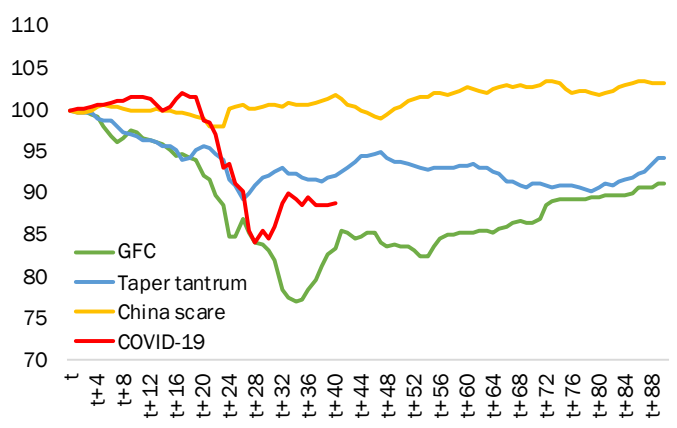

(d) EMBI

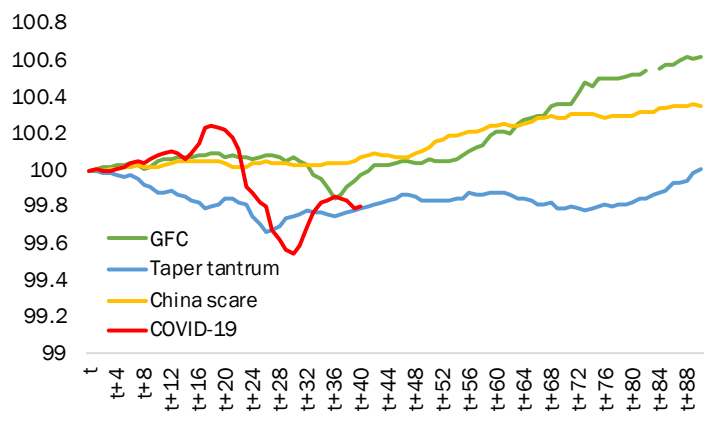

(f) Local currency Bond Index 
Figure 7: Effect of a three standard deviation risk-off shock on the distribution of returns and EPFR flows

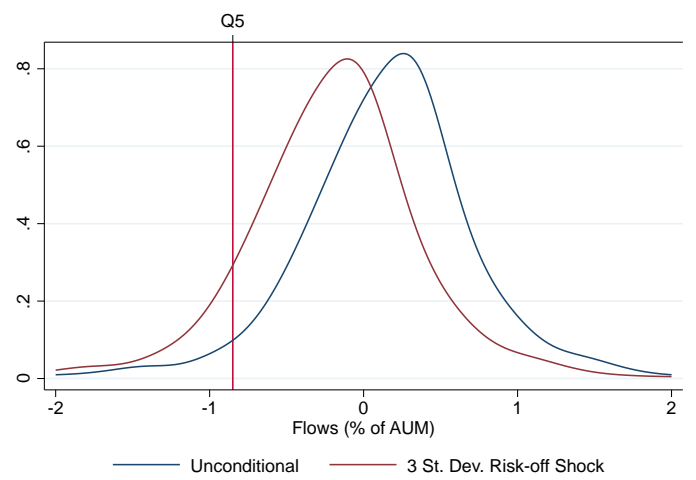

(a) Bond flows

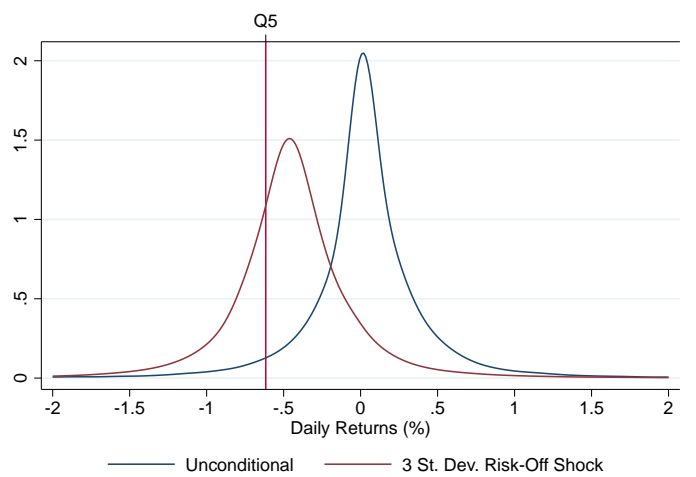

(c) EMBI

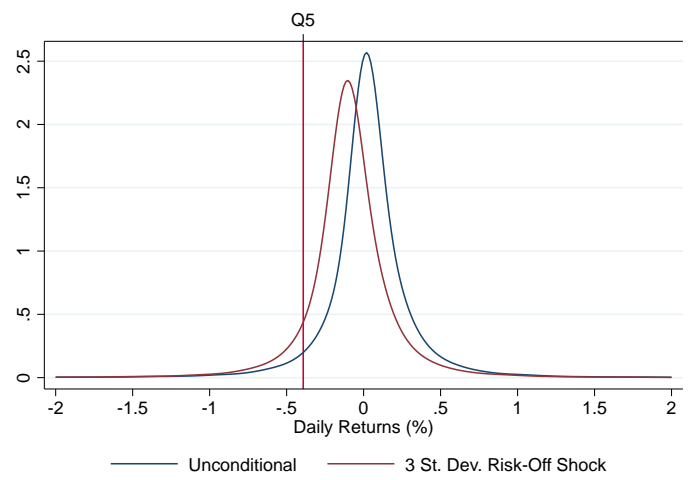

(e) LC Bond Index

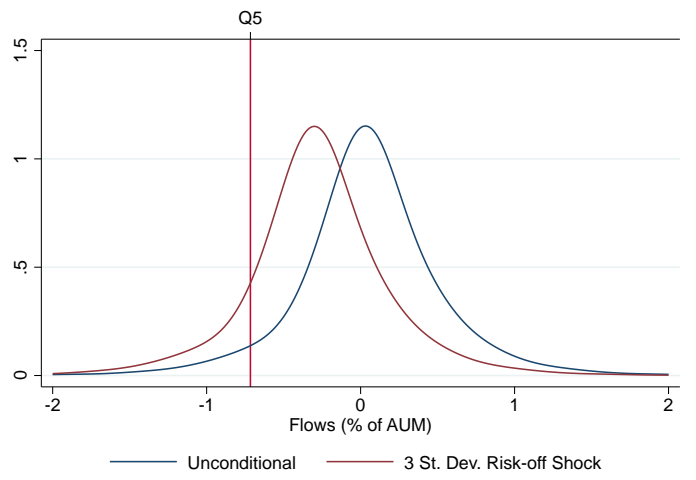

(b) Equity flows

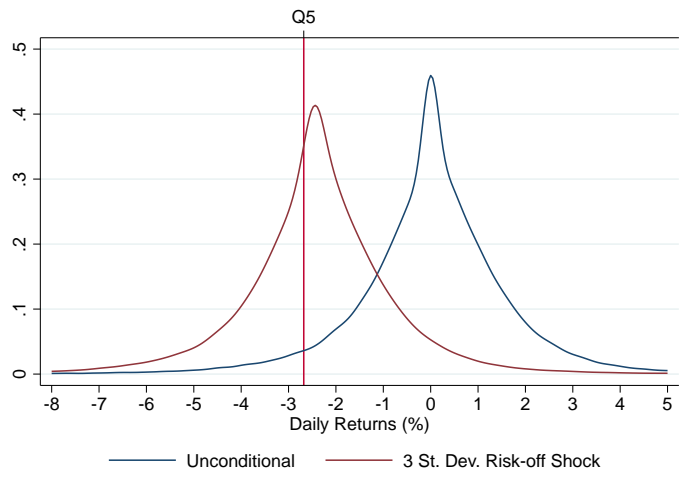

(d) MSCI USD

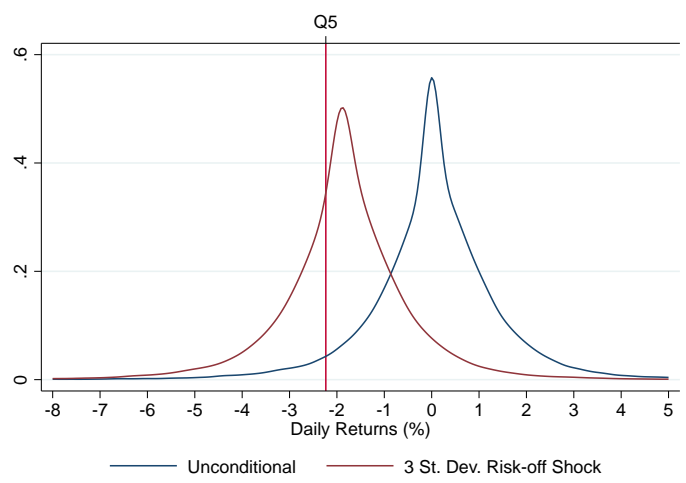

(f) MSCI LC 
Figure 8: Effect of a three standard deviation risk-off BEX shock on the distribution of returns and EPFR flows

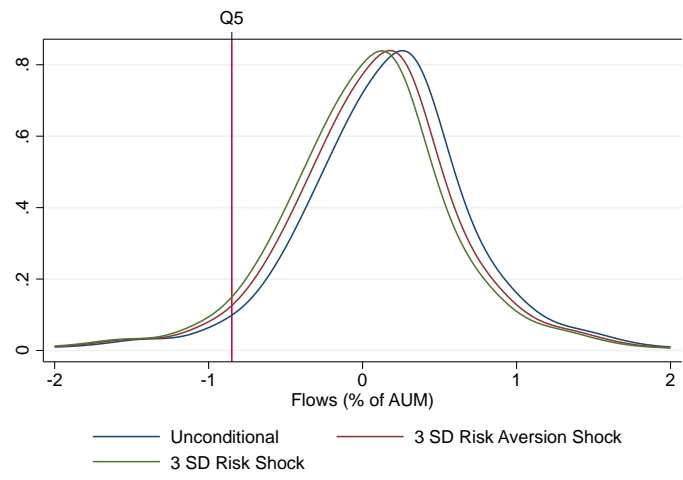

(a) Bond flows

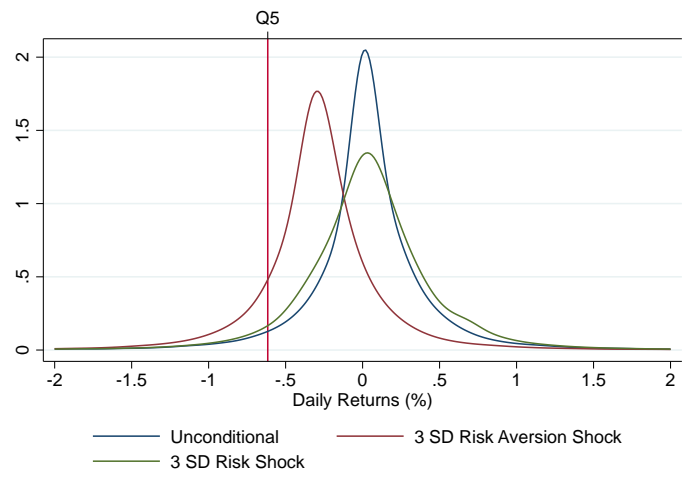

(c) EMBI

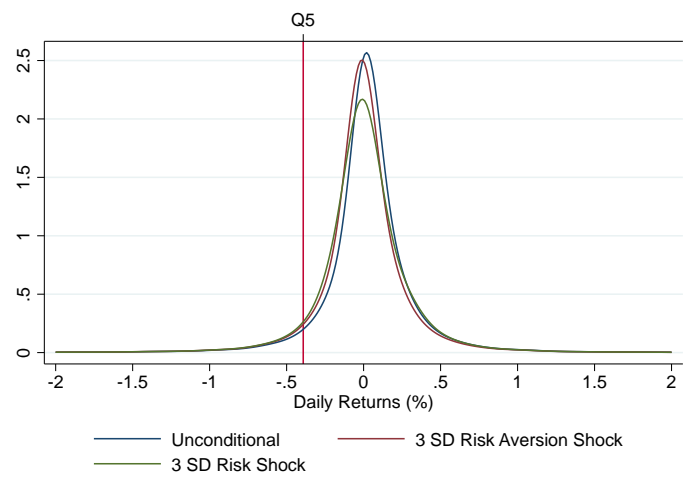

(e) LC Bond Index

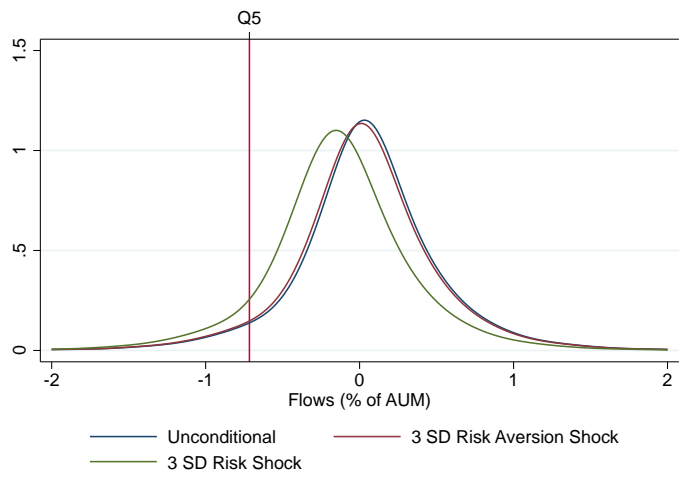

(b) Equity flows

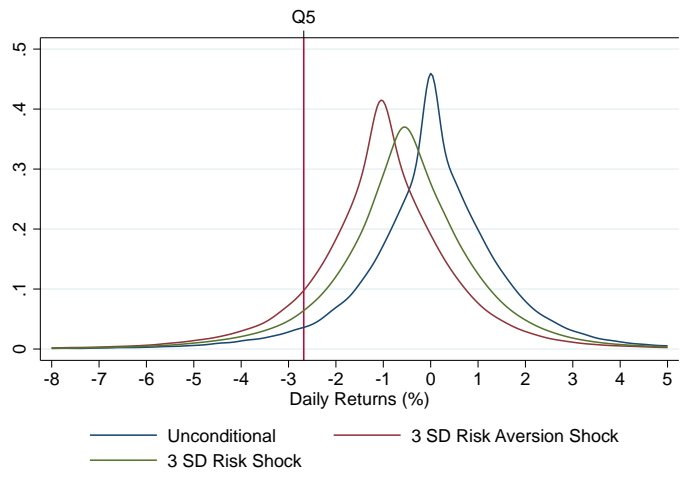

(d) MSCI USD

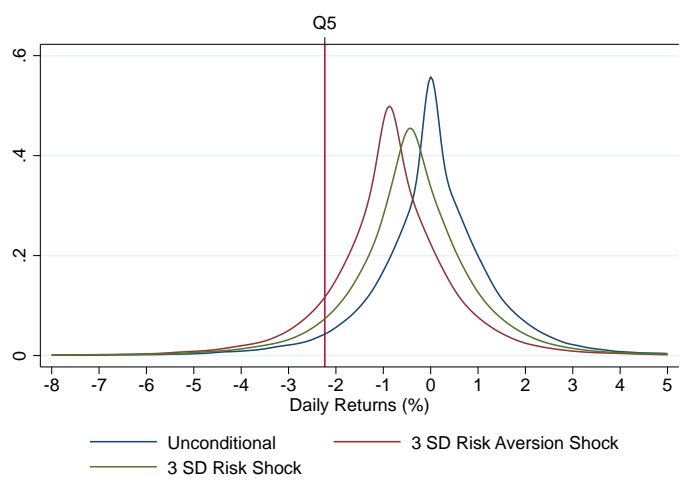

(f) MSCI LC 
Table 1.1: Risk-on/Risk-off Summary Statistics

\begin{tabular}{lccccc}
\hline \hline & & & & & \\
& Q5 & Q50 & Q95 & Skewness & Kurtosis \\
\hline RORO Index & -1.32 & -0.08 & 1.54 & 1.91 & 22.84 \\
Funding Liquidity & -0.90 & 0.01 & 0.86 & 1.15 & 80.71 \\
AE Equity Returns/Volatility & -1.36 & -0.07 & 1.55 & 1.25 & 20.03 \\
Gold and Currencies & -1.70 & -0.01 & 1.77 & 0.14 & 5.77 \\
Corporate Spreads & -1.30 & -0.07 & 1.31 & 2.43 & 34.93 \\
Log Diff. Risk Aversion & -0.72 & -0.00 & 0.74 & 0.03 & 112.09 \\
Log Diff. Uncertainty & -1.12 & -0.06 & 1.27 & 1.36 & 30.86 \\
\hline Observations & 4517 & & & \\
\hline \hline
\end{tabular}

Table 1.2: Emerging Market Summary Statistics

(a) EPFR Country Flows

\begin{tabular}{lccccccc}
\hline \hline & & & & & & & \\
& Mean & St. Dev. & Q5 & Q50 & Q95 & Skewness & Kurtosis \\
\hline Equity Flow: \% of Lagged AUM & 0.05 & 0.49 & -0.71 & 0.04 & 0.81 & 0.76 & 21.93 \\
Equity Flows (Millions USD) & 6.52 & 117.79 & -124.53 & 1.19 & 161.34 & 0.22 & 38.56 \\
Equity AUM (Billions USD) & 18.64 & 27.13 & 0.39 & 6.42 & 82.84 & 2.23 & 7.88 \\
Bond Flow: \% of Lagged AUM & 0.14 & 0.69 & -0.85 & 0.18 & 1.08 & -1.01 & 20.39 \\
Bonds Flows (Millions USD) & 6.37 & 85.76 & -63.06 & 1.98 & 93.64 & -18.46 & 862.13 \\
Bonds AUM (Billions USD) & 8.15 & 10.75 & 0.08 & 3.91 & 35.14 & 2.03 & 7.04 \\
\hline Observations & 18474 & & & & & & \\
\hline \hline
\end{tabular}

(b) Returns

\begin{tabular}{lccccccc}
\hline \hline & & & & & & & \\
& Mean & St. Dev. & Q5 & Q50 & Q95 & Skewness & Kurtosis \\
\hline MSCI LC Return & 0.04 & 1.53 & -2.23 & 0.00 & 2.26 & -0.39 & 21.07 \\
MSCI USD Return & 0.04 & 1.79 & -2.68 & 0.00 & 2.63 & -0.37 & 17.81 \\
EMBI Return & 0.02 & 0.62 & -0.62 & 0.02 & 0.66 & -5.11 & 316.02 \\
LC Bond Return & 0.03 & 0.57 & -0.39 & 0.02 & 0.47 & 0.55 & 1389.67 \\
\hline Observations & 92202 & & & & & \\
\hline \hline
\end{tabular}


Table 2: Impact of a one standard deviation risk-off (RORO) shock

(a) Bond flows

\begin{tabular}{cccccc}
\hline \hline & $(1)$ & $(2)$ & $(3)$ & $(4)$ & $(5)$ \\
& Q5 & Q25 & Q50 & Q75 & Q95 \\
\hline RORO Index & $-0.159^{* * *}$ & $-0.131^{* * *}$ & $-0.117^{* * *}$ & $-0.104^{* * *}$ & $-0.0785^{* * *}$ \\
& $(-13.41)$ & $(-16.63)$ & $(-18.97)$ & $(-18.72)$ & $(-11.45)$ \\
\hline Observations: 16917 & & & & \\
\hline
\end{tabular}

(b) Equity flows

\begin{tabular}{lccccc}
\hline RORO Index & $-0.105^{* * *}$ & $-0.109^{* * *}$ & $-0.111^{* * *}$ & $-0.113^{* * *}$ & $-0.117^{* * *}$ \\
& $(-18.17)$ & $(-35.81)$ & $(-38.53)$ & $(-30.16)$ & $(-17.46)$ \\
\hline Observations: 16967 & & & & \\
\hline
\end{tabular}

(c) USD equity returns

\begin{tabular}{lccccc}
\hline RORO Index & $-0.926^{* * *}$ & $-0.853^{* * *}$ & $-0.814^{* * *}$ & $-0.774^{* * *}$ & $-0.701^{* * *}$ \\
& $(-11.78)$ & $(-10.20)$ & $(-9.52)$ & $(-8.77)$ & $(-7.35)$ \\
\hline Observations: 85033 & & & & \\
\hline
\end{tabular}

(d) Local currency equity returns

\begin{tabular}{lccccc}
\hline RORO Index & $-0.926^{* * *}$ & $-0.853^{* * *}$ & $-0.814^{* * *}$ & $-0.774^{* * *}$ & $-0.701^{* * *}$ \\
& $(-11.78)$ & $(-10.20)$ & $(-9.52)$ & $(-8.77)$ & $(-7.35)$ \\
\hline Observations: 85033 & & & & \\
\hline
\end{tabular}

(e) USD bond returns

\begin{tabular}{lccccc}
\hline RORO Index & $-0.255^{* * *}$ & $-0.187^{* * *}$ & $-0.160^{* * *}$ & $-0.133^{* * *}$ & $-0.0742^{*}$ \\
& $(-5.58)$ & $(-4.87)$ & $(-4.40)$ & $(-3.89)$ & $(-2.42)$ \\
\hline Observations: 72451 & & & &
\end{tabular}

(f) Local currency bond returns

\begin{tabular}{lccccc}
\hline RORO Index & $-0.0734^{* * *}$ & $-0.0484^{* * *}$ & $-0.0408^{* * *}$ & $-0.0321^{* *}$ & -0.00940 \\
& $(-4.35)$ & $(-4.15)$ & $(-3.86)$ & $(-3.15)$ & $(-0.80)$ \\
\hline Observations: 49266 & & & & \\
\hline
\end{tabular}

Table 2 summarizes the results of quantile regressions of a) bond flows, b) equity flows, c) USD MSCI equity returns, d) local currency MSCI equity returns, e) EMBI USD bond returns, and $f$ ) local currency daily total returns on our headline RORO index. Specification includes the full set of control variables, country fixed effects, and year fixed effects. Full results can be found in the Internet Appendix. Bootstrapped standard errors are clustered by country. t-statistics are shown in parentheses. ${ }^{*},{ }^{* *}$, and ${ }^{* * *}$ signify a statistically significant difference in the effect of RORO at the $10 \%, 5 \%$, and $1 \%$ levels, respectively. 
Table 3.1: Impact of a one standard deviation risk-off (BEX) shock on EPFR flows (\% of AUM)

(a) Bond flows

\begin{tabular}{lccccc}
\hline \hline & Q5 & Q25 & Q50 & Q75 & Q95 \\
\hline Log Diff. Risk Aversion & $-0.0331^{*}$ & $-0.0286^{* *}$ & $-0.0264^{* *}$ & $-0.0244^{* * *}$ & $-0.0203^{* * *}$ \\
& $(-1.99)$ & $(-2.65)$ & $(-3.17)$ & $(-3.77)$ & $(-3.38)$ \\
& & & & & \\
Log Diff. Risk & $-0.0574^{* * *}$ & $-0.0486^{* * *}$ & $-0.0443^{* * *}$ & $-0.0403^{* * *}$ & $-0.0323^{* * *}$ \\
& $(-3.95)$ & $(-4.58)$ & $(-4.96)$ & $(-5.31)$ & $(-5.46)$ \\
\hline Observations: 17508 & \multicolumn{5}{c}{} \\
\hline
\end{tabular}

(b) Equity flows

\begin{tabular}{lccccc}
\hline Log Diff. Risk Aversion & $0.0186^{* * *}$ & 0.00130 & $-0.00715^{* *}$ & $-0.0153^{* * *}$ & $-0.0315^{* * *}$ \\
& $(3.60)$ & $(0.42)$ & $(-2.72)$ & $(-5.19)$ & $(-6.27)$ \\
& & & & & \\
Log Diff. Risk & $-0.109^{* * *}$ & $-0.0770^{* * *}$ & $-0.0612^{* * *}$ & $-0.0460^{* * *}$ & $-0.0158^{* *}$ \\
& $(-13.71)$ & $(-17.06)$ & $(-19.48)$ & $(-15.86)$ & $(-2.91)$ \\
\hline
\end{tabular}

Observations: 17559

Table 3.1 summarizes the results of quantile regressions of a) bond flows and b) equity flows on our chosen structural shocks from Bekaert et al 2019. Specification includes the full set of control variables, country fixed effects, and year fixed effects. Full results can be found in the Internet Appendix. Bootstrapped standard errors are clustered by country. $t$-statistics are shown in parentheses. ${ }^{*},{ }^{* *}$, and ${ }^{* * *}$ signify a statistically significant difference in the effect of RORO at the $10 \%, 5 \%$, and $1 \%$ levels, respectively. 
Table 3.2: Impact of a one standard deviation risk-off (BEX) shock on returns (a) MSCI USD

\begin{tabular}{lccccc}
\hline \hline & Q5 & Q25 & Q50 & Q75 & Q95 \\
\hline Log Diff. Risk Aversion & $-0.246^{* * *}$ & $-0.317^{* * *}$ & $-0.351^{* * *}$ & $-0.385^{* * *}$ & $-0.452^{* * *}$ \\
& $(-5.90)$ & $(-7.46)$ & $(-7.59)$ & $(-7.54)$ & $(-7.33)$ \\
& & & & & \\
Log Diff. Risk & $-0.395^{* * *}$ & $-0.262^{* * *}$ & $-0.198^{* * *}$ & $-0.133^{* * *}$ & -0.00816 \\
& $(-9.38)$ & $(-7.79)$ & $(-7.00)$ & $(-5.53)$ & $(-0.37)$ \\
\hline Observations: 85033 & & & & & \\
\hline
\end{tabular}

(b) MSCI Local currency

\begin{tabular}{lccccc}
\hline Log Diff. Risk Aversion & $-0.194^{* * *}$ & $-0.262^{* * *}$ & $-0.294^{* * *}$ & $-0.328^{* * *}$ & $-0.393^{* * *}$ \\
& $(-5.84)$ & $(-7.56)$ & $(-7.61)$ & $(-7.52)$ & $(-7.30)$ \\
& & & & & \\
Log Diff. Risk & $-0.316^{* * *}$ & $-0.206^{* * *}$ & $-0.155^{* * *}$ & $-0.102^{* * *}$ & 0.00257 \\
& $(-7.68)$ & $(-6.63)$ & $(-6.12)$ & $(-4.88)$ & $(0.13)$ \\
\hline Observations: 85054 & & & & & \\
\hline
\end{tabular}

(c) EMBI

\begin{tabular}{lccccc}
\hline Log Diff. Risk Aversion & $-0.0554^{* *}$ & $-0.0921^{* * *}$ & $-0.105^{* * *}$ & $-0.118^{* * *}$ & $-0.151^{* * *}$ \\
& $(-3.22)$ & $(-6.07)$ & $(-5.81)$ & $(-5.39)$ & $(-4.54)$ \\
& & & & & \\
Log Diff. Risk & $-0.116^{* * *}$ & -0.0280 & 0.00310 & $0.0348^{*}$ & $0.114^{* * *}$ \\
& $(-3.39)$ & $(-1.33)$ & $(0.16)$ & $(1.98)$ & $(7.07)$ \\
\hline Observations: 72390 & & & & \\
\hline
\end{tabular}

(d) Local currency bond index

\begin{tabular}{lccccc}
\hline Log Diff. Risk Aversion & 0.00500 & -0.00685 & -0.0102 & -0.0142 & -0.0248 \\
& $(0.14)$ & $(-0.42)$ & $(-0.74)$ & $(-1.23)$ & $(-1.38)$ \\
& & & & & \\
Log Diff. Risk & $-0.0565^{*}$ & -0.0195 & -0.00902 & 0.00333 & $0.0364^{*}$ \\
& $(-2.24)$ & $(-1.79)$ & $(-0.87)$ & $(0.35)$ & $(2.47)$ \\
\hline Observations: 85054 & & & & &
\end{tabular}

Table 3.2 summarizes the results of quantile regressions of a) USD MSCI equity returns, b) local currency MSCI equity returns, c) EMBI USD bond returns, and d) local currency daily total returns on our chosen structural shocks from Bekaert et al 2019. Specification includes the full set of control variables, country fixed effects, and year fixed effects. Full results can be found in the Internet Appendix. Bootstrapped standard errors are clustered by country. t-statistics are shown in parentheses. ${ }^{*}, * *$, and ${ }^{* * *}$ signify a statistically significant difference in the effect of RORO at the $10 \%, 5 \%$, and $1 \%$ levels, respectively. 
Table 4: A one standard deviation risk-off shock \& the distribution of government money market fund assets

\begin{tabular}{|c|c|c|c|c|c|c|c|c|}
\hline & $\begin{array}{l}\text { (1) } \\
\text { Q5 }\end{array}$ & $\begin{array}{c}(2) \\
\text { Q50 }\end{array}$ & $\begin{array}{c}\text { (3) } \\
\text { OLS }\end{array}$ & $\begin{array}{c}\text { (4) } \\
\text { Q95 }\end{array}$ & $\begin{array}{l}\text { (5) } \\
\text { Q5 }\end{array}$ & $\begin{array}{c}(6) \\
\text { Q50 }\end{array}$ & $\begin{array}{c}(7) \\
\text { OLS }\end{array}$ & $\begin{array}{c}(8) \\
\text { Q95 }\end{array}$ \\
\hline RORO Index & $\begin{array}{c}0.167^{* *} \\
(2.87)\end{array}$ & $\begin{array}{c}0.217^{* * * *} \\
(5.43)\end{array}$ & $\begin{array}{c}0.275^{* *} \\
(2.88)\end{array}$ & $\begin{array}{l}0.432^{*} \\
(2.14)\end{array}$ & & & & \\
\hline AE Mkt. Return & $\begin{array}{c}0.0914^{* * *} \\
\quad(6.95)\end{array}$ & $\begin{array}{c}0.0658^{* * *} \\
\quad(6.67)\end{array}$ & $\begin{array}{c}0.100^{* * *} \\
(6.74)\end{array}$ & $\begin{array}{c}0.110^{* * *} \\
(3.85)\end{array}$ & $\begin{array}{c}0.0946^{* * *} \\
\quad(6.53)\end{array}$ & $\begin{array}{c}0.0621^{* * * *} \\
\quad(6.75)\end{array}$ & $\begin{array}{c}0.0965^{* * *} \\
\quad(6.71)\end{array}$ & $\begin{array}{c}0.104^{* *} \\
(2.62)\end{array}$ \\
\hline AE Real GDP Growth (t-1) & $\begin{array}{l}-10.36 \\
(-1.76)\end{array}$ & $\begin{array}{l}0.749 \\
(0.09)\end{array}$ & $\begin{array}{l}-8.561 \\
(-0.96)\end{array}$ & $\begin{array}{l}-41.37 \\
(-1.35)\end{array}$ & $\begin{array}{l}-5.779 \\
(-0.79)\end{array}$ & $\begin{array}{l}-4.893 \\
(-0.83)\end{array}$ & $\begin{array}{l}-9.549 \\
(-1.10)\end{array}$ & $\begin{array}{l}-28.84 \\
(-0.85)\end{array}$ \\
\hline AE Monetary Stance ( $\mathrm{t}-1)$ & $\begin{array}{c}0.494^{* * *} \\
(3.59)\end{array}$ & $\begin{array}{l}0.360^{*} \\
(2.42)\end{array}$ & $\begin{array}{c}0.812^{* * *} \\
(3.33)\end{array}$ & $\begin{array}{c}1.112^{* *} \\
(2.75)\end{array}$ & $\begin{array}{c}0.533^{*} \\
(2.49)\end{array}$ & $\begin{array}{c}0.387^{* *} \\
(2.90)\end{array}$ & $\begin{array}{c}0.773^{* *} \\
(3.26)\end{array}$ & $\begin{array}{l}0.754 \\
(1.34)\end{array}$ \\
\hline Risk Aversion & & & & & $\begin{array}{c}0.182^{*} \\
(2.33)\end{array}$ & $\begin{array}{c}-0.0821 \\
(-1.36)\end{array}$ & $\begin{array}{c}-0.0979 \\
(-0.62)\end{array}$ & $\begin{array}{l}-0.346 \\
(-0.92)\end{array}$ \\
\hline Risk & & & & & $\begin{array}{c}-0.0160 \\
(-0.19)\end{array}$ & $\begin{array}{c}0.309^{* * *} \\
(5.46)\end{array}$ & $\begin{array}{l}0.298 \\
(1.91)\end{array}$ & $\begin{array}{l}0.410 \\
(1.45)\end{array}$ \\
\hline Constant & $\begin{array}{c}-15.69^{* * *} \\
(-8.58)\end{array}$ & $\begin{array}{c}-10.51^{* * *} \\
(-5.96)\end{array}$ & $\begin{array}{c}-16.47^{* * *} \\
(-5.74)\end{array}$ & $\begin{array}{l}-16.41^{*} \\
(-2.51) \\
\end{array}$ & $\begin{array}{c}-16.38^{* * *} \\
(-6.59)\end{array}$ & $\begin{array}{c}-10.02^{* * *} \\
(-5.88)\end{array}$ & $\begin{array}{c}-15.74^{* * *} \\
(-5.74)\end{array}$ & $\begin{array}{l}-14.93 \\
(-1.69)\end{array}$ \\
\hline Observations & 628 & 628 & 628 & 628 & 656 & 656 & 656 & 656 \\
\hline $\begin{array}{l}t \text { statistics in parentheses } \\
{ }^{*} p<0.05,{ }^{* *} p<0.01,{ }^{* * *} p<\end{array}$ & & & & & & & & \\
\hline
\end{tabular}


Table 5: Effect of a COVID-era risk-off shock on the distribution of country EPFR flows

(a) RORO Index

\begin{tabular}{clccc|lccc}
\hline & Panel A: Bonds & Q5 & Q50 & Q95 & Panel B: Equity & Q5 & Q50 & Q95 \\
\hline \hline & Observed flows & -473.56 & 3.73 & 178.13 & Observed flows & -258.62 & -5.79 & 109.69 \\
\hline $\begin{array}{c}\beta \text { (unconditional) } \\
\sigma=1\end{array}$ & $\begin{array}{l}\text { \% of AUM/week } \\
\text { Millions USD }\end{array}$ & -0.16 & -0.12 & -0.08 & \% of AUM/week & -0.11 & -0.11 & -0.12 \\
& & & & & & & \\
& \% of AUM/week & -0.49 & -0.36 & -0.24 & \% of AUM/week & -0.33 & -0.34 & -0.36 \\
\hline $\begin{array}{c}\beta^{*} \text { Covid1Stdev } \\
\sigma=3.1\end{array}$ & Millions USD & -563.70 & -62.60 & 133.63 & Millions USD & -318.15 & -68.72 & 43.36 \\
$\begin{array}{c}\beta^{*} \text { CovidPeak } \\
\sigma=11.56\end{array}$ & \% of AUM/week & -1.84 & -1.35 & -0.91 & \% of AUM/week & -1.21 & -1.28 & -1.35 \\
& Millions USD & -809.69 & -243.61 & 12.18 & Millions USD & -480.60 & -240.44 & -137.65 \\
\hline
\end{tabular}

(b) Risk Aversion (BEX 2020)

\begin{tabular}{clccc|lccc}
\hline & Panel A: Bonds & Q5 & Q50 & Q95 & Panel B: Equity & Q5 & Q50 & Q95 \\
\hline \hline $\begin{array}{c}\beta \text { (unconditional) } \\
\sigma=1\end{array}$ & Observed flows & -473.56 & 3.73 & 178.13 & Observed flows & -258.62 & -5.79 & 109.69 \\
& & & & & & & & \\
& \% of AUM/week & -0.05 & -0.05 & -0.04 & \% of AUM/week & -0.02 & -0.03 & -0.05 \\
& Millions USD & -482.61 & -4.65 & 170.36 & Millions USD & -262.03 & -11.88 & 101.12 \\
\hline $\begin{array}{c}\beta^{*} \text { Covid1Stdev } \\
\sigma=3.1\end{array}$ & \% of AUM/week & -0.15 & -0.14 & -0.13 & \% of AUM/week & -0.06 & -0.10 & -0.15 \\
$\beta^{*}$ CovidPeak & Millions USD & -501.62 & -22.24 & 154.04 & Millions USD & -269.17 & -24.67 & 83.10 \\
$\sigma=11.56$ & \% of AUM/week & -0.57 & -0.53 & -0.49 & \% of AUM/week & -0.22 & -0.38 & -0.54 \\
& Millions USD & -578.20 & -93.10 & 88.29 & Millions USD & -297.95 & -76.19 & 10.55 \\
\hline
\end{tabular}

(c) Risk (BEX 2020)

\begin{tabular}{cllll|lccc}
\hline & Panel A: Bonds & Q5 & Q50 & Q95 & Panel B: Equity & Q5 & Q50 & Q95 \\
\hline \hline & Observed flows & -473.56 & 3.73 & 178.13 & Observed flows & -258.62 & -5.79 & 109.69 \\
\hline $\begin{array}{c}\beta \text { (unconditional) } \\
\sigma=1\end{array}$ & \% of AUM/week & -0.09 & -0.06 & -0.04 & \% of AUM/week & -0.10 & -0.07 & -0.03 \\
& Millions USD & -489.27 & -7.34 & 171.33 & Millions USD & -276.91 & -17.80 & 103.57 \\
\hline $\begin{array}{c}\beta^{*} \text { Covid1Stdev } \\
\sigma=3.1\end{array}$ & \% of AUM/week & -0.27 & -0.19 & -0.12 & \% of AUM/week & -0.31 & -0.20 & -0.10 \\
$\beta^{*}$ CovidPeak & Millions USD & -522.26 & -30.57 & 157.04 & Millions USD & -315.32 & -43.03 & 90.70 \\
$\sigma=11.56$ & \% of AUM/week & -0.99 & -0.70 & -0.43 & \% of AUM/week & -1.16 & -0.76 & -0.39 \\
& Millions USD & -655.15 & -124.17 & 99.49 & Millions USD & -470.03 & -144.68 & 38.87 \\
\hline
\end{tabular}




\title{
Capital Flows in Risky Times: Risk-on/Risk-off and Emerging Market Tail Risk
}

\author{
Anusha Chari $^{*} \quad$ Karlye Dilts Stedman ${ }^{\dagger} \quad$ Christian Lundblad ${ }^{\ddagger}$
}

This Version: October 2, 2020

SUPPLEMENTAL APPENDIX

*Professor of Economics, Department of Economics \& Professor of Finance, Kenan-Flagler Business School, University of North Carolina at Chapel Hill \& NBER. Email: achari@unc.edu

${ }^{\dagger}$ Economist, Research Department, Federal Reserve Bank of Kansas City. Email: karlye.stedman@kc.frb.org The views expressed are those of the authors and do not necessarily reflect those of the Federal Reserve Bank of Kansas City or the Federal Reserve System.

‡Richard "Dick" Levin Distinguished Professor of Finance, Kenan-Flagler Business School, University of North Carolina at Chapel Hill. Email Christian_Lundblad@kenan-flagler.unc.edu 


\section{References from Footnote \#1.}

[1] Alfaro, L., S. Kalemli-Ozcan, and V. Volosovych (2008). Why Doesn't Capital Flow from Rich to Poor Countries? An Empirical Investigation. The Review of Economics and Statistics 90(2), 347-368.

[2] Alfaro, L., S. Kalemli-Ozcan, and V. Volosovych (2014). Sovereigns, Upstream Capital Flows, and Global Imbalances. Journal of the European Economic Association 12(5), 1240-1284.

[3] Avdjiev S, Gambacorta L, Goldberg LS, Schiaffi S. 2019. The shifting drivers of global liquidity. NBER Working Paper No. 23565.

[4] Ammer, J., M. De Pooter, C. J. Erceg, and S. B. Kamin (2016). International Spillovers of Monetary Policy. IFDP Notes, Board of Governors of the Federal Reserve System.

[5] Baskaya, Y. S., J. di Giovanni, S. Kalemli-Ozcan, J.-L. Peydro, and M. F. Ulu (2017). Capital Flows and the International Credit Channel. Journal of International Economics 108(1), S15-S22.

[6] Bauer, M. D., and C. J. Neely. 2014. International channels of the Fed's unconventional monetary policy. Journal of International Money and Finance 44:24-46.

[7] Broner, F., T. Didier, A. Erce, and S. L. Schmukler. 2013. Gross capital flows: Dynamics and crises. Journal of Monetary Economics 60(1):113-33.

[8] Bruning, F. and V. Ivashina (2019). U.S. Monetary Policy and Emerging Market Credit Cycles. Journal of Monetary Economics.

[9] Bruno, V. and H. S. Shin (2014). Cross-Border Banking and Global Liquidity. The Review of Economic Studies 82(2), 535-564.

[10] Bruno, V. and H. S. Shin (2015). Capital Flows and the Risk-taking Channel of Monetary Policy. Journal of Monetary Economics 71, 119 - 132.

[11] Calvo, G. A., L. Leiderman, and C. M. Reinhart (1993). Capital Inflows and Real Exchange Rate Appreciation in Latin America: the Role of External Factors. IMF Staff Papers 40 (1), 108-151.

[12] Calvo, G. A., L. Leiderman, and C. M. Reinhart (1996). Inflows of Capital to Developing Countries in the 1990s. Journal of Economic Perspectives 10(2), 123-139.

[13] Cerutti, E., S. Claessens, and D. Puy (2019). Push Factors and Capital Flows to Emerging Markets: Why Knowing Your Lender Matters more than Fundamentals. Journal of International Economics 119, 133 - 149.

[14] Chen, J., T. Mancini Griffoli, and R. Sahay. 2014. Spillovers from United States monetary policy on emerging markets: Different this time? IMF WorkingPaper No. 14/240. 
[15] Clark, J., N. Converse, B. Coulibaly, and S. Kamin. 2016. Emerging Market Capital Flows and U.S. Monetary Policy. IFDP Notes. Washington: Board of Governors of the Federal Reserve System, October 18.

[16] Dedola, L., G. Rivolta, and L. Stracca (2017). If the Fed Sneezes, Who Catches a Cold? Journal of International Economics 108, S23 - S41.

[17] Dilts Stedman, K. 2019. Unconventional Monetary Policy, (A)Synchronicity and the Yield Curve. Federal Reserve Bank of Kansas City, Research Working Paper No. 19-09.

[18] Eichengreen, B., and P. Gupta. 2014. Tapering talk: The impact of expectations of reduced Federal Reserve security purchases on emerging markets. World Bank Policy Research Working Paper No. 6754.

[19] Fratzscher,M.,M. Lo Duca, and R. Straub. 2016. ECB unconventional monetary policy: Market impact and international spillovers. IMF Economic Review 64(1):36-74.

[20] Fratzscher,M.,M. Lo Duca, and R. Straub. 2018. On the international spillovers of US quantitative easing. Economic Journal 128(608):330-77.

[21] Georgiadis, G., and J. Gr"ab. 2015. Global financial market impact of the announcement of the ECB's extended asset purchase programme. Globalization and Monetary Policy Institute Working Paper 232.

[22] Ghosh, A. R., M. S. Qureshi, J. I. Kim, and J. Zalduendo (2014). Surges. Journal of International Economics 92(2), 266 - 285.

[23] Karolyi, G. A., and K. J. McLaren. 2016. Racing to the Exits: International Transmissions of Funding Shocks During the Federal Reserve's Taper Experiment. Emerging Markets Review 32.

[24] Kim, S. 2001. International transmission of US monetary policy shocks: Evidence from VARs. Journal of Monetary Economics 48(2):339-72.

[25] Kroencke, T. A., M. Schmeling, and A. Schrimpf. 2015. Global asset allocation shifts. BIS Working Paper.

[26] McCauley, R. N., P. McGuire, and V. Sushko. 2015. Global dollar credit: Links to US monetary policy and leverage. Economic Policy 30(82):187-229.

[27] Milesi-Ferretti, G., and C. Tille. 2011. The great retrenchment: International capital flows during the global financial crisis. Economic Policy 26(66):289-346.

[28] Mishra, P., K. Moriyama, P. M. B. N’Diaye, and L. Nguyen. 2014. Impact of Fed tapering announcements on emerging markets. IMF Working Paper No. 14-109.

[29] Moore, J., S. Nam, M. Suh, and A. Tepper. 2013. Estimating the impacts of US LSAPs on emerging market economies' local currency bond markets. Federal Reserve Bank of New York Staff Report 595. 
[30] Neely, C. 2010. The large-asset purchases had large international effects. Federal Reserve Bank of St. Louis Working Paper Series WP2010-018C.

[31] Obstfeld, M. (2015). Trilemmas and Trade-Offs: Living with Financial Globalisation. BIS Working Paper.

[32] Obstfeld, M., J. D. Ostry, and M. S. Qureshi (2018). Global Financial Cycles and the Exchange Rate Regime: A Perspective from Emerging Markets. AEA Papers and Proceedings 108, 499-504.

[33] Rogers, J. H., C. Scotti, and J. H. Wright. 2014. Evaluating asset-market effects of unconventional monetary policy: A multi-country review. Economic Policy 29(80):749-99.

[34] Reinhart, C. and V. Reinhart (2009). Capital Flow Bonanzas: An Encompassing View of the Past and Present. NBER International Seminar on Macroeconomics 2008, 9-62. 
2 Figures 

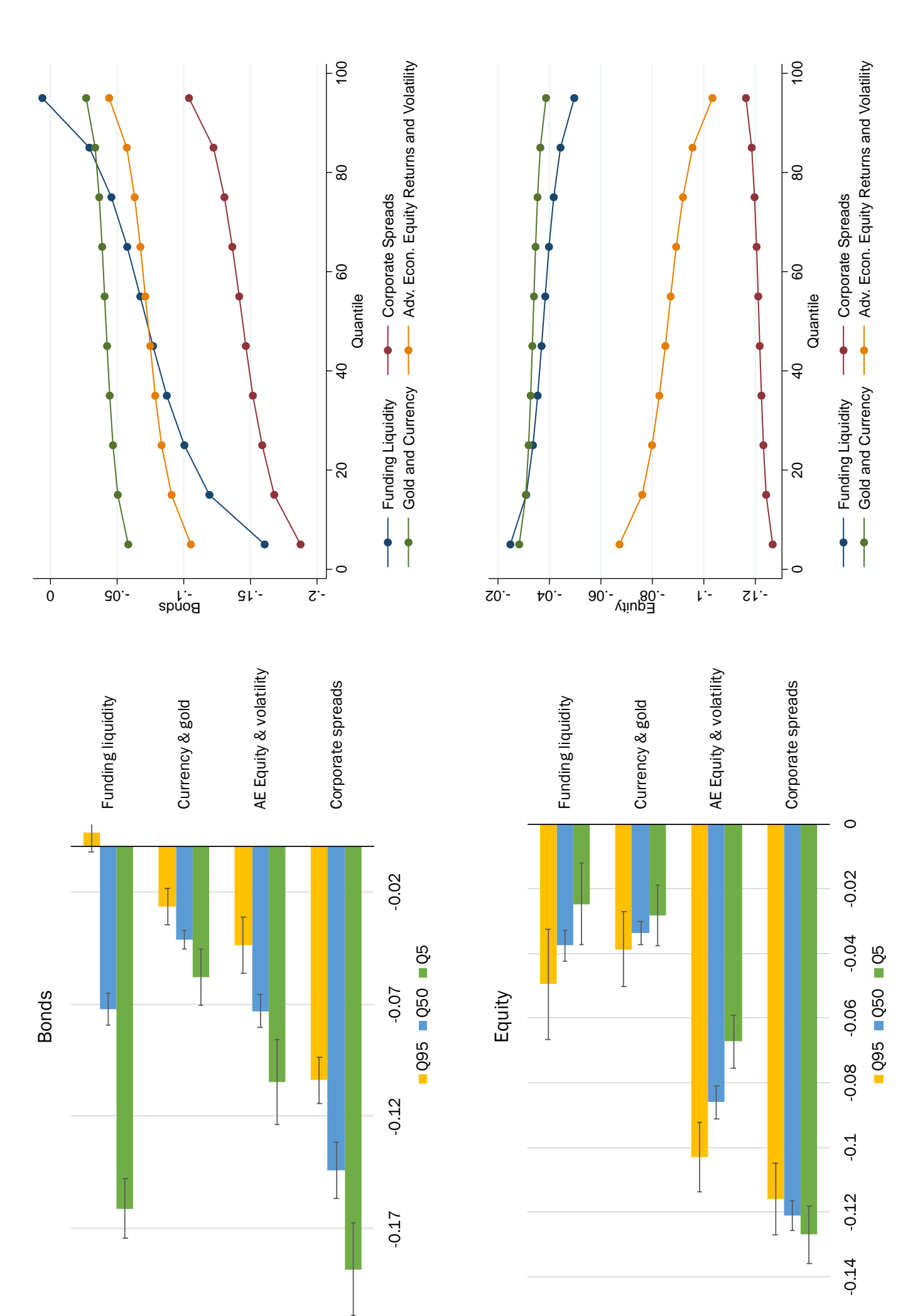

๑ِ 

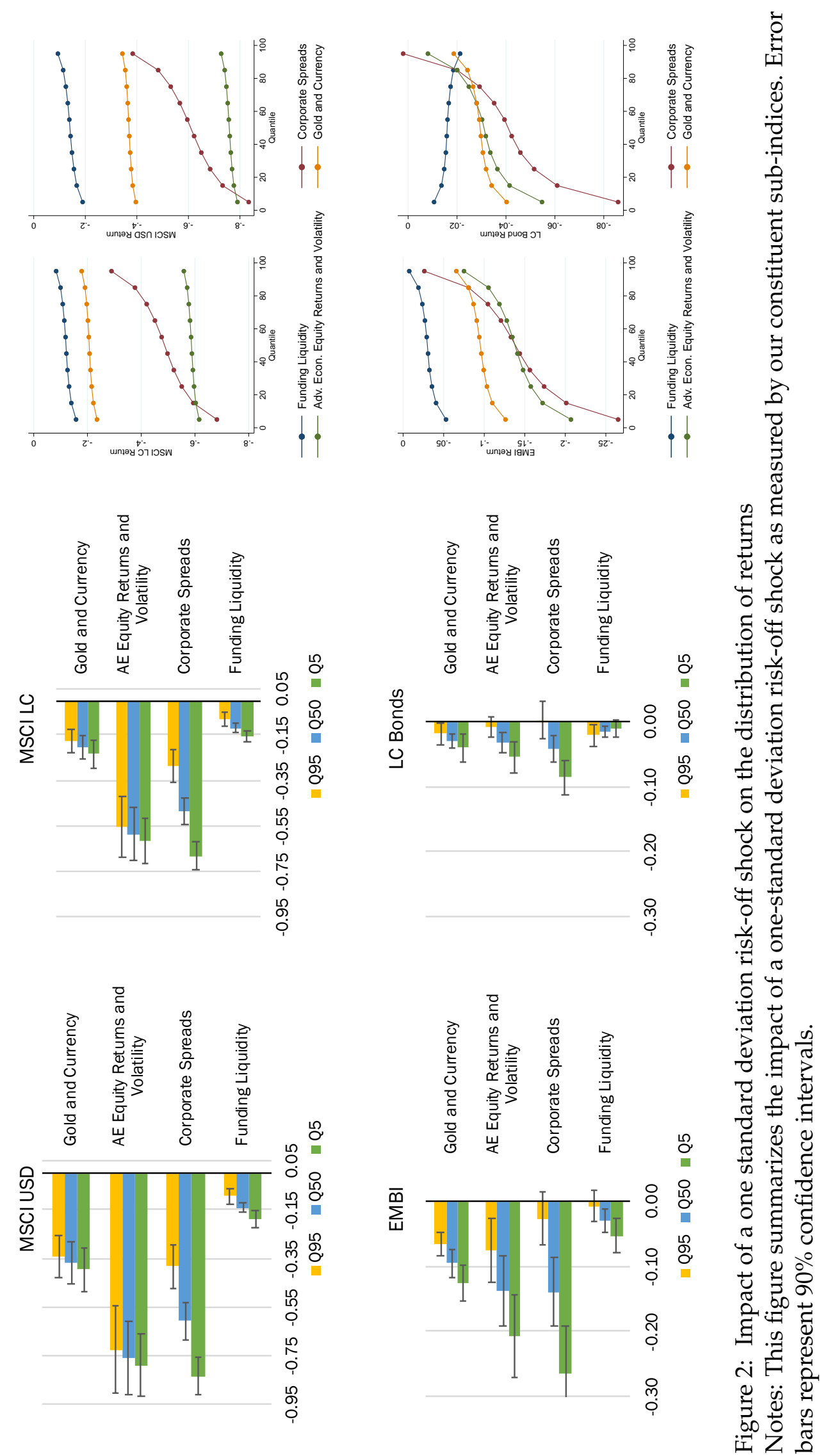


\section{Tables}

Table 1: Sample Countries

\begin{tabular}{ll}
\hline Argentina & Mexico \\
Brazil & Pakistan \\
Chile & Peru \\
China & Philippines \\
Colombia & Poland \\
Czech Republic & Qatar \\
Egypt & Russia \\
Greece & South Africa \\
Hungary & Taiwan \\
India & Thailand* \\
Indonesia & Turkey \\
Malaysia & United Arab Emirates \\
\hline * Indicates eventual exclusion from EMBI, \\
returns extended using S\&P Bond Index.
\end{tabular}

Table 2: Control Variables Summary Statistics

\begin{tabular}{lccccc}
\hline \hline & & & & & \\
& Mean & St. Dev. & Q5 & Q50 & Q95 \\
\hline BIS Policy Rate (t-1) & 6.39 & 6.12 & 1.00 & 5.00 & 15.00 \\
Adv. Market Return & 0.02 & 0.31 & -0.51 & 0.02 & 0.49 \\
Avg. RGDP Growth (8Q) & 0.04 & 0.03 & -0.00 & 0.04 & 0.09 \\
Emerging Mkt. News & -0.01 & 2.81 & -4.10 & 0.00 & 4.10 \\
Exchange rate return & -0.00 & 1.53 & -0.87 & 0.00 & 0.93 \\
REER Growth & 0.05 & 2.12 & -3.09 & 0.14 & 2.87 \\
\hline Observations & 92998 & & & & \\
\hline \hline
\end{tabular}




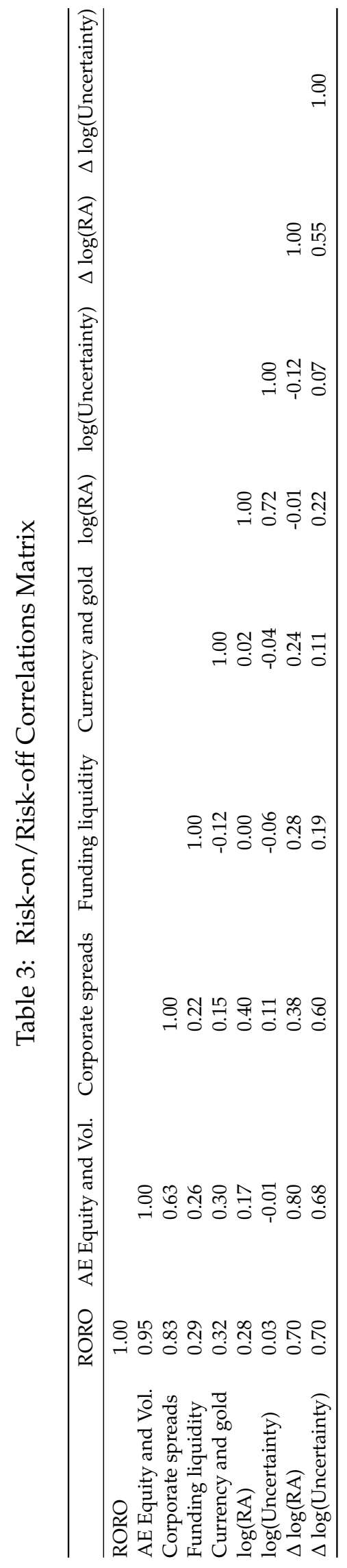


Table 4a: A one standard deviation risk-off (RORO) shock \& the distribution of bond flows

\begin{tabular}{|c|c|c|c|c|c|}
\hline & $\begin{array}{l}\text { (1) } \\
\text { O5 }\end{array}$ & $\begin{array}{c}(2) \\
\text { O25 }\end{array}$ & $\begin{array}{l}(3) \\
\text { O50 }\end{array}$ & $\begin{array}{c}(4) \\
\text { O75 }\end{array}$ & $\begin{array}{c}(5) \\
\text { O95 }\end{array}$ \\
\hline RORO Index & $\begin{array}{c}-0.159^{* * *} \\
(-13.41)\end{array}$ & $\begin{array}{c}-0.131^{* * *} \\
(-16.63)\end{array}$ & $\begin{array}{c}-0.117^{* * *} \\
(-18.97)\end{array}$ & $\begin{array}{c}-0.104^{* * *} \\
(-18.72)\end{array}$ & $\begin{array}{c}-0.0785^{* * *} \\
(-11.45)\end{array}$ \\
\hline Policy Rate (t-1) & $\begin{array}{c}-0.00157 \\
(-0.13)\end{array}$ & $\begin{array}{c}-0.000832 \\
(-0.17)\end{array}$ & $\begin{array}{c}-0.000469 \\
(-0.20)\end{array}$ & $\begin{array}{c}-0.000117 \\
(-0.04)\end{array}$ & $\begin{array}{c}0.000558 \\
(0.06)\end{array}$ \\
\hline $\operatorname{REER}(\mathrm{t}-1)$ & $\begin{array}{c}-0.00187 \\
(-0.75)\end{array}$ & $\begin{array}{c}-0.000738 \\
(-0.77)\end{array}$ & $\begin{array}{c}-0.000182 \\
(-0.32)\end{array}$ & $\begin{array}{c}0.000357 \\
(0.36)\end{array}$ & $\begin{array}{c}0.00139 \\
(0.59)\end{array}$ \\
\hline Avg. RGDP Growth (8Q) & $\begin{array}{l}0.102 \\
(0.12)\end{array}$ & $\begin{array}{l}0.253 \\
(0.64)\end{array}$ & $\begin{array}{l}0.326 \\
(1.16)\end{array}$ & $\begin{array}{l}0.398 \\
(1.20)\end{array}$ & $\begin{array}{l}0.535 \\
(0.78)\end{array}$ \\
\hline Emerging Mkt. News & $\begin{array}{c}-0.00604 \\
(-1.23)\end{array}$ & $\begin{array}{c}-0.0219^{* * *} \\
(-8.78)\end{array}$ & $\begin{array}{c}-0.0297^{* * *} \\
(-14.19)\end{array}$ & $\begin{array}{c}-0.0372^{* * *} \\
(-14.87)\end{array}$ & $\begin{array}{c}-0.0517^{* * *} \\
(-11.06)\end{array}$ \\
\hline Adv. Mkt. Index (t-1) & $\begin{array}{c}-0.00401^{* *} \\
(-2.31)\end{array}$ & $\begin{array}{c}-0.00860^{* * *} \\
(-11.86)\end{array}$ & $\begin{array}{c}-0.0108^{* * *} \\
(-12.21)\end{array}$ & $\begin{array}{c}-0.0130^{* * *} \\
(-9.84)\end{array}$ & $\begin{array}{c}-0.0172^{* * *} \\
(-7.18)\end{array}$ \\
\hline AE Real GDP Growth (t-1) & $\begin{array}{l}1.713 \\
(1.23)\end{array}$ & $\begin{array}{c}-2.658^{* * *} \\
(-3.74)\end{array}$ & $\begin{array}{c}-4.797^{* * *} \\
(-10.29)\end{array}$ & $\begin{array}{c}-6.874^{* * *} \\
(-15.83)\end{array}$ & $\begin{array}{c}-10.85^{* * *} \\
(-11.23)\end{array}$ \\
\hline AE Monetary Stance (t-1) & $\begin{array}{c}0.0613^{* * *} \\
(4.03)\end{array}$ & $\begin{array}{c}-0.0504^{* * *} \\
(-5.24)\end{array}$ & $\begin{array}{c}-0.105^{* * *} \\
(-7.90)\end{array}$ & $\begin{array}{c}-0.158^{* * *} \\
(-8.82)\end{array}$ & $\begin{array}{c}-0.260^{* * *} \\
(-9.22)\end{array}$ \\
\hline $\mathrm{AR}(1)$ & $\begin{array}{c}0.623^{* * *} \\
(16.90)\end{array}$ & $\begin{array}{c}0.540^{* * *} \\
(20.79)\end{array}$ & $\begin{array}{c}0.500^{* * *} \\
(21.04)\end{array}$ & $\begin{array}{c}0.460^{* * *} \\
(19.53)\end{array}$ & $\begin{array}{c}0.385^{* * *} \\
(12.76)\end{array}$ \\
\hline Observations & 16917 & 16917 & 16917 & 16917 & 16917 \\
\hline
\end{tabular}

Notes: This table summarizes the results of quantile regressions of EPFR country bond flows on our headline RORO index. Bootstrapped standard errors are clustered by country. ${ }^{*}, * *$, and ${ }^{* * *}$ denote statistical significance at the $10 \%, 5 \%$, and $1 \%$ levels, respectively. 
Table 4b: A one standard deviation risk-off (RORO) shock \& the distribution of equity flows

\begin{tabular}{|c|c|c|c|c|c|}
\hline & $\begin{array}{l}\text { (1) } \\
\text { O5 }\end{array}$ & $\begin{array}{c}(2) \\
\text { Q25 }\end{array}$ & $\begin{array}{l}(3) \\
\text { O50 }\end{array}$ & $\begin{array}{c}(4) \\
\text { O75 }\end{array}$ & $\begin{array}{c}(5) \\
\text { Q95 }\end{array}$ \\
\hline RORO Index & $\begin{array}{c}-0.105^{* * *} \\
(-18.17)\end{array}$ & $\begin{array}{c}-0.109^{* * *} \\
(-35.81)\end{array}$ & $\begin{array}{c}-0.111^{* * *} \\
(-38.53)\end{array}$ & $\begin{array}{c}-0.113^{* * *} \\
(-30.16)\end{array}$ & $\begin{array}{c}-0.117^{* * *} \\
(-17.46)\end{array}$ \\
\hline Policy Rate (t-1) & $\begin{array}{c}-0.00106 \\
(-0.38)\end{array}$ & $\begin{array}{c}0.0000958 \\
(0.06)\end{array}$ & $\begin{array}{c}0.000666 \\
(0.48)\end{array}$ & $\begin{array}{c}0.00121 \\
(0.78)\end{array}$ & $\begin{array}{c}0.00228 \\
(0.89)\end{array}$ \\
\hline REER $(t-1)$ & $\begin{array}{c}-0.000456 \\
(-0.57)\end{array}$ & $\begin{array}{c}-0.000559^{+} \\
(-1.57)\end{array}$ & $\begin{array}{c}-0.000609^{*} \\
(-1.77)\end{array}$ & $\begin{array}{c}-0.000657 \\
(-1.29)\end{array}$ & $\begin{array}{c}-0.000751 \\
(-0.77)\end{array}$ \\
\hline Avg. RGDP Growth (8Q) & $\begin{array}{l}-0.882 \\
(-1.33)\end{array}$ & $\begin{array}{c}0.0375 \\
(0.22)\end{array}$ & $\begin{array}{c}0.489^{* *} \\
(2.42)\end{array}$ & $\begin{array}{c}0.922^{* *} \\
(2.14)\end{array}$ & $\begin{array}{l}1.766^{*} \\
(1.91)\end{array}$ \\
\hline Emerging Mkt. News & $\begin{array}{c}-0.0270^{* * *} \\
(-11.29)\end{array}$ & $\begin{array}{c}-0.0228^{* * *} \\
(-18.06)\end{array}$ & $\begin{array}{c}-0.0208^{* * *} \\
(-17.22)\end{array}$ & $\begin{array}{c}-0.0188^{* * *} \\
(-12.14)\end{array}$ & $\begin{array}{c}-0.0150^{* * *} \\
(-5.47)\end{array}$ \\
\hline Adv. Mkt. Index (t-1) & $\begin{array}{c}0.00130 \\
(1.12)\end{array}$ & $\begin{array}{c}0.000847 \\
(0.89)\end{array}$ & $\begin{array}{c}0.000625 \\
(0.57)\end{array}$ & $\begin{array}{c}0.000411 \\
(0.30)\end{array}$ & $\begin{array}{c}-0.00000494 \\
(-0.00)\end{array}$ \\
\hline AE Real GDP Growth (t-1) & $\begin{array}{l}-1.709^{*} \\
(-1.72)\end{array}$ & $\begin{array}{c}-0.00564 \\
(-0.01)\end{array}$ & $\begin{array}{c}0.831^{+} \\
(1.47)\end{array}$ & $\begin{array}{c}1.632^{* *} \\
(2.03)\end{array}$ & $\begin{array}{c}3.194^{* *} \\
(2.22)\end{array}$ \\
\hline AE Monetary Stance $(\mathrm{t}-1)$ & $\begin{array}{c}0.0926^{* * *} \\
(4.38)\end{array}$ & $\begin{array}{c}-0.0300^{* * *} \\
(-2.62)\end{array}$ & $\begin{array}{c}-0.0903^{* * *} \\
(-8.91)\end{array}$ & $\begin{array}{c}-0.148^{* * *} \\
(-11.35)\end{array}$ & $\begin{array}{c}-0.260^{* * *} \\
(-11.09)\end{array}$ \\
\hline $\operatorname{AR}(1)$ & $\begin{array}{c}0.342^{* * *} \\
(5.86)\end{array}$ & $\begin{array}{c}0.366^{* * *} \\
(10.81)\end{array}$ & $\begin{array}{c}0.378^{* * *} \\
(13.76)\end{array}$ & $\begin{array}{c}0.389^{* * *} \\
(13.61)\end{array}$ & $\begin{array}{c}0.411^{* * * *} \\
(8.77)\end{array}$ \\
\hline Observations & 16967 & 16967 & 16967 & 16967 & 16967 \\
\hline
\end{tabular}

Notes: This table summarizes the results of quantile regressions of EPFR country equity flows on our headline RORO index. Bootstrapped standard errors are clustered by country. ${ }^{*}, * *$, and ${ }^{* * *}$ denote statistical significance at the $10 \%, 5 \%$, and $1 \%$ levels, respectively. 
Table 4c: A one standard deviation risk-off (RORO) shock \& the distribution of USD equity returns

\begin{tabular}{|c|c|c|c|c|c|}
\hline & $\begin{array}{l}\text { (1) } \\
\text { Q5 }\end{array}$ & $\begin{array}{c}(2) \\
\text { Q25 }\end{array}$ & $\begin{array}{c}\text { (3) } \\
\text { Q50 }\end{array}$ & $\begin{array}{c}(4) \\
\text { Q75 }\end{array}$ & $\begin{array}{c}5) \\
\text { Q95 }\end{array}$ \\
\hline RORO Index & $\begin{array}{c}-0.926^{* * *} \\
(-11.78)\end{array}$ & $\begin{array}{c}-0.853^{* * *} \\
(-10.20)\end{array}$ & $\begin{array}{c}-0.814^{* * *} \\
(-9.52)\end{array}$ & $\begin{array}{c}-0.774^{* * *} \\
(-8.77)\end{array}$ & $\begin{array}{c}-0.701^{* * *} \\
(-7.35)\end{array}$ \\
\hline $\operatorname{REER}(\mathrm{t}-1)$ & $\begin{array}{c}0.00403 \\
(0.97)\end{array}$ & $\begin{array}{c}0.000196 \\
(0.15)\end{array}$ & $\begin{array}{c}-0.00180^{* * *} \\
(-3.24)\end{array}$ & $\begin{array}{c}-0.00388^{* *} \\
(-2.01)\end{array}$ & $\begin{array}{c}-0.00772^{+} \\
(-1.62)\end{array}$ \\
\hline BIS Policy Rate (t-1) & $\begin{array}{c}-0.0290^{* *} \\
(-2.04)\end{array}$ & $\begin{array}{c}-0.0101^{* * *} \\
(-2.83)\end{array}$ & $\begin{array}{c}-0.000217 \\
(-0.06)\end{array}$ & $\begin{array}{l}0.0101 \\
(1.11)\end{array}$ & $\begin{array}{c}0.0290^{+} \\
(1.45)\end{array}$ \\
\hline Avg. RGDP Growth (8Q) & $\begin{array}{l}1.122 \\
(0.55)\end{array}$ & $\begin{array}{l}0.401 \\
(0.47)\end{array}$ & $\begin{array}{c}0.0249 \\
(0.08)\end{array}$ & $\begin{array}{l}-0.368 \\
(-0.64)\end{array}$ & $\begin{array}{l}-1.091 \\
(-0.63)\end{array}$ \\
\hline Emerging Mkt. News & $\begin{array}{c}0.0119^{* * *} \\
(4.15)\end{array}$ & $\begin{array}{c}0.00495^{* * *} \\
\quad(2.94)\end{array}$ & $\begin{array}{c}0.00132 \\
(0.71)\end{array}$ & $\begin{array}{c}-0.00247 \\
(-0.95)\end{array}$ & $\begin{array}{c}-0.00945^{* *} \\
(-2.12)\end{array}$ \\
\hline Adv. market index $(\mathrm{t}-1)$ & $\begin{array}{c}-0.0287^{* * *} \\
(-5.59)\end{array}$ & $\begin{array}{c}-0.0104^{* * *} \\
(-4.04)\end{array}$ & $\begin{array}{c}-0.000876 \\
(-0.50)\end{array}$ & $\begin{array}{c}0.00911^{* * *} \\
\quad(5.19)\end{array}$ & $\begin{array}{c}0.0275^{* * *} \\
(7.42)\end{array}$ \\
\hline AE Real GDP Growth (t-1) & $\begin{array}{c}16.55^{* * *} \\
(6.88)\end{array}$ & $\begin{array}{c}5.742^{* * *} \\
(5.20)\end{array}$ & $\begin{array}{l}0.113 \\
(0.15)\end{array}$ & $\begin{array}{c}-5.776^{* * *} \\
(-5.57)\end{array}$ & $\begin{array}{c}-16.60^{* * *} \\
(-7.21)\end{array}$ \\
\hline AE Monetary Stance $(\mathrm{t}-1)$ & $\begin{array}{c}-0.130^{* *} \\
(-2.11)\end{array}$ & $\begin{array}{c}-0.0114 \\
(-0.37)\end{array}$ & $\begin{array}{c}0.0505^{* * *} \\
(2.76)\end{array}$ & $\begin{array}{c}0.115^{\text {*** }} \\
(8.87)\end{array}$ & $\begin{array}{c}0.234^{* * *} \\
(6.48)\end{array}$ \\
\hline Observations & 85097 & 85097 & 85097 & 85097 & 85097 \\
\hline
\end{tabular}

Notes: This table summarizes the results of quantile regressions of MSCI USD daily total returns on our headline RORO index. Bootstrapped standard errors are clustered by country. ${ }^{*},{ }^{* *}$, and ${ }^{* * *}$ denote statistical significance at the $10 \%, 5 \%$, and $1 \%$ levels, respectively. 
Table 4d: A one standard deviation risk-off (RORO) shock \& the distribution of local currency equity returns

\begin{tabular}{|c|c|c|c|c|c|}
\hline & $\begin{array}{l}\text { (1) } \\
\text { Q5 }\end{array}$ & $\begin{array}{c}(2) \\
\text { Q25 }\end{array}$ & $\begin{array}{c}(3) \\
\text { Q50 }\end{array}$ & $\begin{array}{c}(4) \\
\text { Q75 }\end{array}$ & $\begin{array}{c}(5) \\
\text { Q95 }\end{array}$ \\
\hline RORO Index & $\begin{array}{c}-0.728^{* * *} \\
(-12.78)\end{array}$ & $\begin{array}{c}-0.663^{* * *} \\
(-10.89)\end{array}$ & $\begin{array}{c}-0.630^{* * *} \\
(-10.07)\end{array}$ & $\begin{array}{c}-0.595^{* * *} \\
(-9.18)\end{array}$ & $\begin{array}{c}-0.529^{* * *} \\
(-7.37)\end{array}$ \\
\hline $\operatorname{REER}(\mathrm{t}-1)$ & $\begin{array}{c}0.00171 \\
(0.48)\end{array}$ & $\begin{array}{c}0.0000832 \\
(0.07)\end{array}$ & $\begin{array}{c}-0.000740 \\
(-1.18)\end{array}$ & $\begin{array}{c}-0.00160 \\
(-0.96)\end{array}$ & $\begin{array}{c}-0.00324 \\
(-0.79)\end{array}$ \\
\hline BIS Policy Rate (t-1) & $\begin{array}{c}-0.0280^{* * *} \\
(-2.73)\end{array}$ & $\begin{array}{c}-0.00972^{* *} \\
(-2.27)\end{array}$ & $\begin{array}{c}-0.000461 \\
(-0.20)\end{array}$ & $\begin{array}{c}0.00925^{* *} \\
(2.44)\end{array}$ & $\begin{array}{c}0.0276^{* * *} \\
(2.82)\end{array}$ \\
\hline Avg. RGDP Growth (8Q) & $\begin{array}{l}-0.233 \\
(-0.12)\end{array}$ & $\begin{array}{c}-0.0161 \\
(-0.02)\end{array}$ & $\begin{array}{c}0.0933 \\
(0.37)\end{array}$ & $\begin{array}{l}0.208 \\
(0.33)\end{array}$ & $\begin{array}{l}0.425 \\
(0.23)\end{array}$ \\
\hline Emerging Mkt. News & $\begin{array}{l}0.0103^{* * *} \\
\quad(3.86)\end{array}$ & $\begin{array}{c}0.00374^{* *} \\
(2.39)\end{array}$ & $\begin{array}{c}0.000436 \\
(0.27)\end{array}$ & $\begin{array}{c}-0.00302 \\
(-1.36)\end{array}$ & $\begin{array}{c}-0.00957^{* *} \\
(-2.47)\end{array}$ \\
\hline Adv. market index $(t-1)$ & $\begin{array}{c}-0.0233^{* * *} \\
(-5.52)\end{array}$ & $\begin{array}{c}-0.00778^{* * *} \\
(-3.49)\end{array}$ & $\begin{array}{l}0.0000977 \\
(0.06)\end{array}$ & $\begin{array}{c}0.00836^{* * *} \\
(4.74)\end{array}$ & $\begin{array}{c}0.0240^{* * *} \\
(7.61)\end{array}$ \\
\hline AE Real GDP Growth (t-1) & $\begin{array}{c}14.32^{* * *} \\
(5.15)\end{array}$ & $\begin{array}{c}4.716^{* * *} \\
(4.09)\end{array}$ & $\begin{array}{l}-0.143 \\
(-0.20)\end{array}$ & $\begin{array}{c}-5.239^{* * *} \\
(-4.58)\end{array}$ & $\begin{array}{c}-14.88^{* * *} \\
(-5.41)\end{array}$ \\
\hline AE Monetary Stance (t-1) & $\begin{array}{c}-0.134^{* *} \\
(-2.52)\end{array}$ & $\begin{array}{c}-0.0197 \\
(-0.77)\end{array}$ & $\begin{array}{c}0.0382^{* *} \\
(2.52)\end{array}$ & $\begin{array}{c}0.0990^{* * *} \\
(8.28)\end{array}$ & $\begin{array}{c}0.214^{* * *} \\
(6.38)\end{array}$ \\
\hline Observations & 85118 & 85118 & 85118 & 85118 & 85118 \\
\hline \multicolumn{6}{|c|}{$\begin{array}{l}\text { statistics in parentheses } \\
{ }^{+} p<0.15,{ }^{*} p<0.10,{ }^{* *} p<0.05,{ }^{* * *} p<0.01\end{array}$} \\
\hline
\end{tabular}


Table 4e: A one standard deviation risk-off (RORO) shock \& the distribution of USD bond returns

\begin{tabular}{|c|c|c|c|c|c|}
\hline & $\begin{array}{l}\text { (1) } \\
\text { Q5 }\end{array}$ & $\begin{array}{c}(2) \\
\text { Q25 }\end{array}$ & $\begin{array}{c}\text { (3) } \\
\text { Q50 }\end{array}$ & $\begin{array}{l}\text { (4) } \\
\text { Q75 }\end{array}$ & $\begin{array}{c}\text { (5) } \\
\text { Q95 }\end{array}$ \\
\hline RORO Index & $\begin{array}{c}-0.255^{* * *} \\
(-5.58)\end{array}$ & $\begin{array}{c}-0.187^{* * *} \\
(-4.87)\end{array}$ & $\begin{array}{c}-0.160^{* * *} \\
(-4.40)\end{array}$ & $\begin{array}{c}-0.133^{* * *} \\
(-3.89)\end{array}$ & $\begin{array}{c}-0.0742^{* *} \\
(-2.42)\end{array}$ \\
\hline $\operatorname{REER}(\mathrm{t}-1)$ & $\begin{array}{c}0.00298 \\
(0.99)\end{array}$ & $\begin{array}{c}0.000591 \\
(0.71)\end{array}$ & $\begin{array}{c}-0.000371^{+} \\
(-1.48)\end{array}$ & $\begin{array}{c}-0.00130 \\
(-1.32)\end{array}$ & $\begin{array}{c}-0.00337 \\
(-1.17)\end{array}$ \\
\hline BIS Policy Rate (t-1) & $\begin{array}{c}-0.0112 \\
(-0.98)\end{array}$ & $\begin{array}{c}-0.00405^{*} \\
(-1.76)\end{array}$ & $\begin{array}{c}-0.00119 \\
(-0.59)\end{array}$ & $\begin{array}{c}0.00158 \\
(0.29)\end{array}$ & $\begin{array}{c}0.00774 \\
(0.57)\end{array}$ \\
\hline Avg. RGDP Growth (8Q) & $\begin{array}{l}2.489 \\
(1.41)\end{array}$ & $\begin{array}{l}0.674 \\
(1.44)\end{array}$ & $\begin{array}{c}-0.0559 \\
(-0.30)\end{array}$ & $\begin{array}{l}-0.761 \\
(-1.28)\end{array}$ & $\begin{array}{l}-2.332 \\
(-1.36)\end{array}$ \\
\hline Emerging Mkt. News & $\begin{array}{c}0.00803^{* * *} \\
(6.69)\end{array}$ & $\begin{array}{c}0.00281^{* * *} \\
(4.16)\end{array}$ & $\begin{array}{c}0.000702 \\
(0.74)\end{array}$ & $\begin{array}{c}-0.00133 \\
(-0.97)\end{array}$ & $\begin{array}{c}-0.00586^{* *} \\
(-2.47)\end{array}$ \\
\hline Adv. market index (t-1) & $\begin{array}{c}-0.0129^{* * *} \\
(-2.82)\end{array}$ & $\begin{array}{c}-0.00368^{* * *} \\
(-2.84)\end{array}$ & $\begin{array}{c}0.0000428 \\
(0.08)\end{array}$ & $\begin{array}{c}0.00364^{* * *} \\
(2.78)\end{array}$ & $\begin{array}{c}0.0117^{* * *} \\
(2.78)\end{array}$ \\
\hline AE Real GDP Growth (t-1) & $\begin{array}{c}9.564^{* * *} \\
(3.47)\end{array}$ & $\begin{array}{c}2.169^{* * *} \\
(3.06)\end{array}$ & $\begin{array}{c}-0.805^{* * *} \\
(-4.58)\end{array}$ & $\begin{array}{c}-3.679^{* * *} \\
(-4.90)\end{array}$ & $\begin{array}{c}-10.08^{* * *} \\
(-3.97)\end{array}$ \\
\hline AE Monetary Stance (t-1) & $\begin{array}{c}0.0708^{* * *} \\
(2.82)\end{array}$ & $\begin{array}{c}0.0472^{* * *} \\
(4.63)\end{array}$ & $\begin{array}{c}0.0378^{* * *} \\
(6.61)\end{array}$ & $\begin{array}{c}0.0286^{* * *} \\
\quad(4.08)\end{array}$ & $\begin{array}{c}0.00825 \\
(0.44)\end{array}$ \\
\hline Observations & 72451 & 72451 & 72451 & 72451 & 72451 \\
\hline
\end{tabular}

Notes: This table summarizes the results of quantile regressions of EMBI daily total returns on our headline RORO index. Bootstrapped standard errors are clustered by country. ${ }^{*}, * *$, and ${ }^{* * *}$ denote statistical significance at the $10 \%, 5 \%$, and $1 \%$ levels, respectively. 
Table 4f: A one standard deviation risk-off (RORO) shock \& the distribution of local currency bond returns

\begin{tabular}{|c|c|c|c|c|c|}
\hline & $\begin{array}{l}\text { (1) } \\
\text { Q5 }\end{array}$ & $\begin{array}{c}(2) \\
\text { Q25 }\end{array}$ & $\begin{array}{c}(3) \\
\text { Q50 }\end{array}$ & $\begin{array}{c}(4) \\
\text { Q75 }\end{array}$ & $\begin{array}{c}(5) \\
\text { Q95 }\end{array}$ \\
\hline RORO Index & $\begin{array}{c}-0.0734^{* * *} \\
(-4.35)\end{array}$ & $\begin{array}{c}-0.0484^{* * *} \\
(-4.15)\end{array}$ & $\begin{array}{c}-0.0408^{* * *} \\
(-3.86)\end{array}$ & $\begin{array}{c}-0.0321^{* * *} \\
(-3.15)\end{array}$ & $\begin{array}{c}-0.00940 \\
(-0.80)\end{array}$ \\
\hline $\operatorname{REER}(\mathrm{t}-1)$ & $\begin{array}{c}-0.00458 \\
(-0.43)\end{array}$ & $\begin{array}{c}-0.00128 \\
(-0.62)\end{array}$ & $\begin{array}{c}-0.000272 \\
(-0.60)\end{array}$ & $\begin{array}{c}0.000868 \\
(0.49)\end{array}$ & $\begin{array}{c}0.00386 \\
(0.38)\end{array}$ \\
\hline BIS Policy Rate (t-1) & $\begin{array}{c}-0.0447^{* * *} \\
(-2.77)\end{array}$ & $\begin{array}{c}-0.0121^{* * *} \\
(-3.18)\end{array}$ & $\begin{array}{c}-0.00207 \\
(-0.61)\end{array}$ & $\begin{array}{c}0.00920^{*} \\
(1.91)\end{array}$ & $\begin{array}{c}0.0388^{* * *} \\
(2.66)\end{array}$ \\
\hline Avg. RGDP Growth (8Q) & $\begin{array}{l}-0.286 \\
(-0.11)\end{array}$ & $\begin{array}{l}-0.621 \\
(-1.05)\end{array}$ & $\begin{array}{c}-0.724^{* * *} \\
(-3.73)\end{array}$ & $\begin{array}{l}-0.839 \\
(-1.41)\end{array}$ & $\begin{array}{l}-1.144 \\
(-0.43)\end{array}$ \\
\hline Emerging Mkt. News & $\begin{array}{c}0.000428 \\
(0.24)\end{array}$ & $\begin{array}{c}-0.00245^{* *} \\
(-1.96)\end{array}$ & $\begin{array}{c}-0.00334^{* * *} \\
(-2.66)\end{array}$ & $\begin{array}{c}-0.00433^{\text {*** }} \\
(-3.02)\end{array}$ & $\begin{array}{c}-0.00695^{* *} \\
(-2.42)\end{array}$ \\
\hline Adv. market index (t-1) & $\begin{array}{c}-0.00960^{* *} \\
(-1.97)\end{array}$ & $\begin{array}{c}-0.00222^{*} \\
(-1.78)\end{array}$ & $\begin{array}{l}0.0000356 \\
(0.05)\end{array}$ & $\begin{array}{c}0.00259^{* * *} \\
(5.61)\end{array}$ & $\begin{array}{c}0.00929^{* *} \\
(2.51)\end{array}$ \\
\hline AE Real GDP Growth (t-1) & $\begin{array}{l}1.977 \\
(1.10)\end{array}$ & $\begin{array}{c}-0.0349 \\
(-0.08)\end{array}$ & $\begin{array}{c}-0.651^{* *} \\
(-2.54)\end{array}$ & $\begin{array}{c}-1.347^{* * *} \\
(-3.29)\end{array}$ & $\begin{array}{l}-3.176^{*} \\
(-1.91)\end{array}$ \\
\hline AE Monetary Stance $(\mathrm{t}-1)$ & $\begin{array}{c}0.00256 \\
(0.10)\end{array}$ & $\begin{array}{c}0.00131 \\
(0.12)\end{array}$ & $\begin{array}{c}0.000923 \\
(0.07)\end{array}$ & $\begin{array}{c}0.000490 \\
(0.03)\end{array}$ & $\begin{array}{c}-0.000649 \\
(-0.02)\end{array}$ \\
\hline Observations & 49232 & 49232 & 49232 & 49232 & 49232 \\
\hline
\end{tabular}

Notes: This table summarizes the results of quantile regressions of local currency daily total returns on our headline RORO index. Bootstrapped standard errors are clustered by country. ${ }^{*}{ }^{* *}$, and ${ }^{* * *}$ denote statistical significance at the $10 \%, 5 \%$, and $1 \%$ levels, respectively. 
Table 5a: A one standard deviation risk-off (BEX) shock \& the distribution of bond flows

\begin{tabular}{|c|c|c|c|c|c|}
\hline & $\begin{array}{l}\text { (1) } \\
\text { Q5 }\end{array}$ & $\begin{array}{c}(2) \\
\text { Q25 }\end{array}$ & $\begin{array}{c}(3) \\
\text { Q50 }\end{array}$ & $\begin{array}{c}(4) \\
\text { Q75 }\end{array}$ & $\begin{array}{c}(5) \\
\text { Q95 }\end{array}$ \\
\hline Log Diff. Risk Aversion & $\begin{array}{c}-0.0331^{* *} \\
(-1.99)\end{array}$ & $\begin{array}{c}-0.0286^{* * *} \\
(-2.65)\end{array}$ & $\begin{array}{c}-0.0264^{* * *} \\
(-3.17)\end{array}$ & $\begin{array}{c}-0.0244^{* * *} \\
(-3.77)\end{array}$ & $\begin{array}{c}-0.0203^{* * *} \\
(-3.38)\end{array}$ \\
\hline Log Diff. Risk & $\begin{array}{c}-0.0574^{* * *} \\
(-3.95)\end{array}$ & $\begin{array}{c}-0.0486^{* * *} \\
(-4.58)\end{array}$ & $\begin{array}{c}-0.0443^{* * *} \\
(-4.96)\end{array}$ & $\begin{array}{c}-0.0403^{* * *} \\
(-5.31)\end{array}$ & $\begin{array}{c}-0.0323^{* * *} \\
(-5.46)\end{array}$ \\
\hline Policy Rate (t-1) & $\begin{array}{c}-0.00179 \\
(-0.15)\end{array}$ & $\begin{array}{c}-0.000831 \\
(-0.18)\end{array}$ & $\begin{array}{c}-0.000372 \\
(-0.18)\end{array}$ & $\begin{array}{l}0.0000651 \\
\quad(0.02)\end{array}$ & $\begin{array}{c}0.000937 \\
(0.10)\end{array}$ \\
\hline $\operatorname{REER}(\mathrm{t}-1)$ & $\begin{array}{c}-0.00190 \\
(-0.79)\end{array}$ & $\begin{array}{c}-0.000759 \\
(-0.86)\end{array}$ & $\begin{array}{c}-0.000216 \\
(-0.41)\end{array}$ & $\begin{array}{c}0.000301 \\
(0.32)\end{array}$ & $\begin{array}{c}0.00133 \\
(0.58)\end{array}$ \\
\hline Avg. RGDP Growth (8Q) & $\begin{array}{l}0.229 \\
(0.27)\end{array}$ & $\begin{array}{l}0.332 \\
(0.81)\end{array}$ & $\begin{array}{l}0.381 \\
(1.31)\end{array}$ & $\begin{array}{l}0.428 \\
(1.30)\end{array}$ & $\begin{array}{l}0.521 \\
(0.77)\end{array}$ \\
\hline Emerging Mkt. News & $\begin{array}{c}0.00326 \\
(0.78)\end{array}$ & $\begin{array}{c}-0.0144^{* * *} \\
(-6.62)\end{array}$ & $\begin{array}{c}-0.0229^{* * *} \\
(-12.30)\end{array}$ & $\begin{array}{c}-0.0309^{* * *} \\
(-14.30)\end{array}$ & $\begin{array}{c}-0.0469^{* * *} \\
(-12.43)\end{array}$ \\
\hline Adv. Mkt. Index (t-1) & $\begin{array}{c}-0.00477^{* * *} \\
(-2.94)\end{array}$ & $\begin{array}{c}-0.00793^{* * *} \\
(-10.76)\end{array}$ & $\begin{array}{c}-0.00943^{* * *} \\
(-10.33)\end{array}$ & $\begin{array}{c}-0.0109^{* * *} \\
(-8.07)\end{array}$ & $\begin{array}{c}-0.0137^{* * *} \\
(-5.69)\end{array}$ \\
\hline AE Real GDP Growth (t-1) & $\begin{array}{c}3.658^{* * *} \\
(2.89)\end{array}$ & $\begin{array}{c}-1.748^{* * *} \\
(-2.85)\end{array}$ & $\begin{array}{c}-4.325^{* * *} \\
(-10.32)\end{array}$ & $\begin{array}{c}-6.778^{* * *} \\
(-15.08)\end{array}$ & $\begin{array}{c}-11.67^{* * *} \\
(-12.03)\end{array}$ \\
\hline AE Monetary Stance (t-1) & $\begin{array}{c}0.0415^{* * *} \\
(3.19)\end{array}$ & $\begin{array}{c}-0.0620^{* * *} \\
(-5.76)\end{array}$ & $\begin{array}{c}-0.111^{* * *} \\
(-7.64)\end{array}$ & $\begin{array}{c}-0.158^{* * *} \\
(-8.36)\end{array}$ & $\begin{array}{c}-0.252^{* * *} \\
(-8.75)\end{array}$ \\
\hline $\operatorname{AR}(1)$ & $\begin{array}{c}0.661^{* * *} \\
(17.60)\end{array}$ & $\begin{array}{c}0.555^{* * *} \\
(21.60)\end{array}$ & $\begin{array}{c}0.504^{* * *} \\
(21.91)\end{array}$ & $\begin{array}{c}0.456^{* * *} \\
(19.64)\end{array}$ & $\begin{array}{c}0.361^{* * *} \\
(11.88)\end{array}$ \\
\hline Observations & 17508 & 17508 & 17508 & 17508 & 17508 \\
\hline
\end{tabular}

Notes: This table summarizes the results of quantile regressions of EPFR country bond flows on our BEX constituent indices. Bootstrapped standard errors are clustered by country. ${ }^{*}, * *$, and ${ }^{* * *}$ denote statistical significance at the $10 \%, 5 \%$, and $1 \%$ levels, respectively. 
Table 5b: A one standard deviation risk-off (BEX) shock \& the distribution of equity flows

\begin{tabular}{|c|c|c|c|c|c|}
\hline & $\begin{array}{l}\text { (1) } \\
\text { Q5 }\end{array}$ & $\begin{array}{c}(2) \\
\text { Q25 }\end{array}$ & $\begin{array}{l}\text { (3) } \\
\text { Q50 }\end{array}$ & $\begin{array}{l}\text { (4) } \\
\text { Q75 }\end{array}$ & $\begin{array}{c}\text { (5) } \\
\text { Q95 }\end{array}$ \\
\hline Log Diff. Risk Aversion & $\begin{array}{c}0.0186^{* * *} \\
(3.60)\end{array}$ & $\begin{array}{c}0.00130 \\
(0.42)\end{array}$ & $\begin{array}{c}-0.00715^{* * *} \\
(-2.72)\end{array}$ & $\begin{array}{c}-0.0153^{* * *} \\
(-5.19)\end{array}$ & $\begin{array}{c}-0.0315^{* * *} \\
(-6.27)\end{array}$ \\
\hline Log Diff. Risk & $\begin{array}{c}-0.109^{* * *} \\
(-13.71)\end{array}$ & $\begin{array}{c}-0.0770^{* * *} \\
(-17.06)\end{array}$ & $\begin{array}{c}-0.0612^{* * *} \\
(-19.48)\end{array}$ & $\begin{array}{c}-0.0460^{* * *} \\
(-15.86)\end{array}$ & $\begin{array}{c}-0.0158^{* * *} \\
(-2.91)\end{array}$ \\
\hline Policy Rate (t-1) & $\begin{array}{c}-0.000778 \\
(-0.30)\end{array}$ & $\begin{array}{c}0.000106 \\
(0.07)\end{array}$ & $\begin{array}{c}0.000537 \\
(0.40)\end{array}$ & $\begin{array}{c}0.000953 \\
(0.60)\end{array}$ & $\begin{array}{c}0.00178 \\
(0.68)\end{array}$ \\
\hline $\operatorname{REER}(\mathrm{t}-1)$ & $\begin{array}{c}-0.000286 \\
(-0.33)\end{array}$ & $\begin{array}{c}-0.000633^{*} \\
(-1.78)\end{array}$ & $\begin{array}{c}-0.000802^{* *} \\
(-2.15)\end{array}$ & $\begin{array}{c}-0.000965^{+} \\
(-1.62)\end{array}$ & $\begin{array}{c}-0.00129 \\
(-1.10)\end{array}$ \\
\hline Avg. RGDP Growth (8Q) & $\begin{array}{l}-0.904 \\
(-1.40)\end{array}$ & $\begin{array}{c}0.0573 \\
(0.31)\end{array}$ & $\begin{array}{c}0.526^{* * *} \\
(3.09)\end{array}$ & $\begin{array}{c}0.979 * * * \\
(2.64)\end{array}$ & $\begin{array}{c}1.878^{* *} \\
(2.26)\end{array}$ \\
\hline Emerging Mkt. News & $\begin{array}{c}-0.0195^{* * *} \\
(-7.23)\end{array}$ & $\begin{array}{c}-0.0185^{* * *} \\
(-14.37)\end{array}$ & $\begin{array}{c}-0.0180^{* * *} \\
(-12.01)\end{array}$ & $\begin{array}{c}-0.0175^{* * *} \\
(-7.99)\end{array}$ & $\begin{array}{c}-0.0166^{* * *} \\
(-4.13)\end{array}$ \\
\hline Adv. Mkt. Index (t-1) & $\begin{array}{c}0.00342^{* *} \\
(2.56)\end{array}$ & $\begin{array}{c}0.00164^{+} \\
(1.48)\end{array}$ & $\begin{array}{c}0.000777 \\
(0.65)\end{array}$ & $\begin{array}{c}-0.0000610 \\
(-0.04)\end{array}$ & $\begin{array}{c}-0.00172 \\
(-0.90)\end{array}$ \\
\hline AE Real GDP Growth (t-1) & $\begin{array}{l}-2.017^{*} \\
(-1.86)\end{array}$ & $\begin{array}{l}0.267 \\
(0.49)\end{array}$ & $\begin{array}{l}1.379^{*} \\
(1.90)\end{array}$ & $\begin{array}{c}2.455^{* *} \\
(2.33)\end{array}$ & $\begin{array}{c}4.590^{* *} \\
(2.45)\end{array}$ \\
\hline AE Monetary Stance (t-1) & $\begin{array}{c}0.0779^{* * *} \\
(2.79)\end{array}$ & $\begin{array}{c}-0.0302^{* *} \\
(-2.38)\end{array}$ & $\begin{array}{c}-0.0828^{* * *} \\
(-9.29)\end{array}$ & $\begin{array}{c}-0.134^{* * *} \\
(-10.07)\end{array}$ & $\begin{array}{c}-0.235^{* * *} \\
(-8.09)\end{array}$ \\
\hline $\operatorname{AR}(1)$ & $\begin{array}{c}0.349^{* * *} \\
(5.83)\end{array}$ & $\begin{array}{c}0.372^{* * *} \\
(11.50)\end{array}$ & $\begin{array}{c}0.383^{* * *} \\
(15.06)\end{array}$ & $\begin{array}{c}0.394^{* * *} \\
(14.21)\end{array}$ & $\begin{array}{c}0.415^{* * *} \\
(8.25)\end{array}$ \\
\hline Observations & 17559 & 17559 & 17559 & 17559 & 17559 \\
\hline
\end{tabular}

Notes: This table summarizes the results of quantile regressions of EPFR country equity flows on our BEX constituent indices. Bootstrapped standard errors are clustered by country. ${ }^{*}, * *$, and ${ }^{* * *}$ denote statistical significance at the $10 \%, 5 \%$, and $1 \%$ levels, respectively. 
Table 5c: A one standard deviation risk-off (BEX) shock \& the distribution of USD equity returns

\begin{tabular}{|c|c|c|c|c|c|}
\hline & $\begin{array}{l}\text { (1) } \\
\text { Q5 }\end{array}$ & $\begin{array}{c}(2) \\
\text { Q25 }\end{array}$ & $\begin{array}{c}(3) \\
\text { Q50 }\end{array}$ & $\begin{array}{c}(4) \\
\text { Q75 }\end{array}$ & $\begin{array}{c}(5) \\
\text { Q95 }\end{array}$ \\
\hline Log Diff. Risk Aversion & $\begin{array}{c}-0.246^{* * *} \\
(-5.90)\end{array}$ & $\begin{array}{c}-0.317^{* * *} \\
(-7.46)\end{array}$ & $\begin{array}{c}-0.351^{* * *} \\
(-7.59)\end{array}$ & $\begin{array}{c}-0.385^{* * *} \\
(-7.54)\end{array}$ & $\begin{array}{c}-0.452^{* * *} \\
(-7.33)\end{array}$ \\
\hline Log Diff. Risk & $\begin{array}{c}-0.395^{* * *} \\
(-9.38)\end{array}$ & $\begin{array}{c}-0.262^{* * *} \\
(-7.79)\end{array}$ & $\begin{array}{c}-0.198^{* * *} \\
(-7.00)\end{array}$ & $\begin{array}{c}-0.133^{* * *} \\
(-5.53)\end{array}$ & $\begin{array}{c}-0.00816 \\
(-0.37)\end{array}$ \\
\hline $\operatorname{REER}(\mathrm{t}-1)$ & $\begin{array}{c}0.00262 \\
(0.58)\end{array}$ & $\begin{array}{c}-0.000642 \\
(-0.47)\end{array}$ & $\begin{array}{c}-0.00221^{* * *} \\
(-3.77)\end{array}$ & $\begin{array}{c}-0.00382^{*} \\
(-1.92)\end{array}$ & $\begin{array}{c}-0.00687 \\
(-1.39)\end{array}$ \\
\hline BIS Policy Rate (t-1) & $\begin{array}{c}-0.0314^{*} \\
(-1.81)\end{array}$ & $\begin{array}{c}-0.0104^{* *} \\
(-2.53)\end{array}$ & $\begin{array}{c}-0.000321 \\
(-0.10)\end{array}$ & $\begin{array}{c}0.0100 \\
(1.06)\end{array}$ & $\begin{array}{l}0.0297 \\
(1.35)\end{array}$ \\
\hline Avg. RGDP Growth (8Q) & $\begin{array}{l}2.783 \\
(1.28)\end{array}$ & $\begin{array}{l}1.064 \\
(1.23)\end{array}$ & $\begin{array}{l}0.239 \\
(0.59)\end{array}$ & $\begin{array}{l}-0.609 \\
(-0.87)\end{array}$ & $\begin{array}{l}-2.219 \\
(-1.16)\end{array}$ \\
\hline Emerging Mkt. News & $\begin{array}{c}0.00456^{+} \\
(1.57)\end{array}$ & $\begin{array}{c}-0.00217^{+} \\
(-1.46)\end{array}$ & $\begin{array}{c}-0.00540^{* * *} \\
(-3.21)\end{array}$ & $\begin{array}{c}-0.00872^{* * *} \\
(-3.61)\end{array}$ & $\begin{array}{c}-0.0150^{* * *} \\
(-3.51)\end{array}$ \\
\hline Adv. market index $(\mathrm{t}-1)$ & $\begin{array}{c}-0.0332^{* * *} \\
(-6.12)\end{array}$ & $\begin{array}{c}-0.0106^{* * *} \\
(-4.18)\end{array}$ & $\begin{array}{c}0.000308 \\
(0.16)\end{array}$ & $\begin{array}{l}0.0115^{* * *} \\
\quad(5.08)\end{array}$ & $\begin{array}{c}0.0327^{* * *} \\
(7.52)\end{array}$ \\
\hline AE Real GDP Growth (t-1) & $\begin{array}{c}20.63^{* * *} \\
(7.85)\end{array}$ & $\begin{array}{c}7.095^{* * *} \\
(6.22)\end{array}$ & $\begin{array}{l}0.590 \\
(0.80)\end{array}$ & $\begin{array}{c}-6.088^{* * *} \\
(-5.89)\end{array}$ & $\begin{array}{c}-18.77^{* * *} \\
(-7.80)\end{array}$ \\
\hline AE Monetary Stance (t-1) & $\begin{array}{c}-0.252^{* * *} \\
(-4.21)\end{array}$ & $\begin{array}{c}-0.0901^{* * *} \\
(-3.41)\end{array}$ & $\begin{array}{c}-0.0125 \\
(-0.83)\end{array}$ & $\begin{array}{c}0.0671^{* * *} \\
\quad(5.10)\end{array}$ & $\begin{array}{c}0.218^{* * *} \\
(5.71)\end{array}$ \\
\hline Observations & 85033 & 85033 & 85033 & 85033 & 85033 \\
\hline
\end{tabular}

Notes: This table summarizes the results of quantile regressions of MSCI USD daily total returns on our BEX constituent indices. Bootstrapped standard errors are clustered by country. ${ }^{*}, *$, and ${ }^{* * *}$ denote statistical significance at the $10 \%, 5 \%$, and $1 \%$ levels, respectively. 
Table 5d: A one standard deviation risk-off (BEX) shock \& the distribution of local currency equity returns

\begin{tabular}{|c|c|c|c|c|c|}
\hline & $\begin{array}{l}\text { (1) } \\
\text { Q5 }\end{array}$ & $\begin{array}{c}\text { (2) } \\
\text { Q25 }\end{array}$ & $\begin{array}{c}\text { (3) } \\
\text { Q50 }\end{array}$ & $\begin{array}{c}\text { (4) } \\
\text { Q75 }\end{array}$ & $\begin{array}{c}5) \\
\text { Q95 }\end{array}$ \\
\hline Log Diff. Risk Aversion & $\begin{array}{c}-0.194^{* * *} \\
(-5.84)\end{array}$ & $\begin{array}{c}-0.262^{* * *} \\
(-7.56)\end{array}$ & $\begin{array}{c}-0.294^{* * *} \\
(-7.61)\end{array}$ & $\begin{array}{c}-0.328^{* * *} \\
(-7.52)\end{array}$ & $\begin{array}{c}-0.393^{* * *} \\
(-7.30)\end{array}$ \\
\hline Log Diff. Risk & $\begin{array}{c}-0.316^{* * *} \\
(-7.68)\end{array}$ & $\begin{array}{c}-0.206^{* * *} \\
(-6.63)\end{array}$ & $\begin{array}{c}-0.155^{* * *} \\
(-6.12)\end{array}$ & $\begin{array}{c}-0.102^{* * *} \\
(-4.88)\end{array}$ & $\begin{array}{c}0.00257 \\
(0.13)\end{array}$ \\
\hline $\operatorname{REER}(\mathrm{t}-1)$ & $\begin{array}{c}0.000634 \\
(0.16)\end{array}$ & $\begin{array}{c}-0.000501 \\
(-0.41)\end{array}$ & $\begin{array}{c}-0.00102^{*} \\
(-1.71)\end{array}$ & $\begin{array}{c}-0.00157 \\
(-0.93)\end{array}$ & $\begin{array}{c}-0.00265 \\
(-0.62)\end{array}$ \\
\hline BIS Policy Rate (t-1) & $\begin{array}{c}-0.0299^{* * *} \\
(-3.28)\end{array}$ & $\begin{array}{c}-0.00982^{* * *} \\
(-2.88)\end{array}$ & $\begin{array}{c}-0.000566 \\
(-0.28)\end{array}$ & $\begin{array}{c}0.00921^{* *} \\
(2.42)\end{array}$ & $\begin{array}{c}0.0284^{* * *} \\
\quad(3.02)\end{array}$ \\
\hline Avg. RGDP Growth (8Q) & $\begin{array}{l}0.694 \\
(0.34)\end{array}$ & $\begin{array}{l}0.418 \\
(0.58)\end{array}$ & $\begin{array}{l}0.291 \\
(0.98)\end{array}$ & $\begin{array}{l}0.157 \\
(0.21)\end{array}$ & $\begin{array}{l}-0.106 \\
(-0.05)\end{array}$ \\
\hline Emerging Mkt. News & $\begin{array}{c}0.00374 \\
(1.31)\end{array}$ & $\begin{array}{c}-0.00182 \\
(-1.36)\end{array}$ & $\begin{array}{c}-0.00438^{* * *} \\
(-3.02)\end{array}$ & $\begin{array}{c}-0.00708^{* * *} \\
(-3.28)\end{array}$ & $\begin{array}{c}-0.0124^{* * *} \\
(-3.06)\end{array}$ \\
\hline Adv. market index $(\mathrm{t}-1)$ & $\begin{array}{c}-0.0260^{* * *} \\
(-5.92)\end{array}$ & $\begin{array}{c}-0.00768^{* * *} \\
(-3.44)\end{array}$ & $\begin{array}{c}0.000716 \\
(0.38)\end{array}$ & $\begin{array}{c}0.00959^{* * *} \\
(4.83)\end{array}$ & $\begin{array}{c}0.0270^{* * *} \\
(8.11)\end{array}$ \\
\hline AE Real GDP Growth (t-1) & $\begin{array}{c}16.50^{* * *} \\
(5.42)\end{array}$ & $\begin{array}{c}5.401^{* * *} \\
(4.61)\end{array}$ & $\begin{array}{l}0.302 \\
(0.44)\end{array}$ & $\begin{array}{c}-5.088^{* * *} \\
(-4.38)\end{array}$ & $\begin{array}{c}-15.65^{* * *} \\
(-5.40)\end{array}$ \\
\hline AE Monetary Stance $(\mathrm{t}-1)$ & $\begin{array}{c}-0.226^{* * *} \\
(-4.46)\end{array}$ & $\begin{array}{c}-0.0785^{* * *} \\
(-3.55)\end{array}$ & $\begin{array}{c}-0.0107 \\
(-0.74) \\
\end{array}$ & $\begin{array}{c}0.0609^{* * *} \\
(4.40)\end{array}$ & $\begin{array}{c}0.201^{* * *} \\
(5.91)\end{array}$ \\
\hline Observations & 85054 & 85054 & 85054 & 85054 & 85054 \\
\hline
\end{tabular}

Notes: This table summarizes the results of quantile regressions of MSCI LC daily total returns on our BEX constituent indices. Bootstrapped standard errors are clustered by country. ${ }^{*},{ }^{* *}$, and ${ }^{* * *}$ denote statistical significance at the $10 \%, 5 \%$, and $1 \%$ levels, respectively. 
Table 5e: A one standard deviation risk-off (BEX) shock \& the distribution of USD bond returns

\begin{tabular}{|c|c|c|c|c|c|}
\hline & $\begin{array}{l}\text { (1) } \\
\text { Q5 }\end{array}$ & $\begin{array}{c}(2) \\
\text { Q25 }\end{array}$ & $\begin{array}{c}\text { (3) } \\
\text { Q50 }\end{array}$ & $\begin{array}{c}(4) \\
\text { Q75 }\end{array}$ & $\begin{array}{c}(5) \\
\text { Q95 }\end{array}$ \\
\hline Log Diff. Risk Aversion & $\begin{array}{c}-0.0554^{* * *} \\
(-3.22)\end{array}$ & $\begin{array}{c}-0.0921^{* * *} \\
(-6.07)\end{array}$ & $\begin{array}{c}-0.105^{* * *} \\
(-5.81)\end{array}$ & $\begin{array}{c}-0.118^{* * *} \\
(-5.39)\end{array}$ & $\begin{array}{c}-0.151^{* * *} \\
(-4.54)\end{array}$ \\
\hline Log Diff. Risk & $\begin{array}{c}-0.116^{* * *} \\
(-3.39)\end{array}$ & $\begin{array}{c}-0.0280 \\
(-1.33)\end{array}$ & $\begin{array}{c}0.00310 \\
(0.16)\end{array}$ & $\begin{array}{c}0.0348^{* *} \\
(1.98)\end{array}$ & $\begin{array}{c}0.114^{* * *} \\
(7.07)\end{array}$ \\
\hline $\operatorname{REER}(\mathrm{t}-1)$ & $\begin{array}{c}0.00322 \\
(0.98)\end{array}$ & $\begin{array}{c}0.000467 \\
(0.56)\end{array}$ & $\begin{array}{c}-0.000504^{*} \\
(-1.78)\end{array}$ & $\begin{array}{c}-0.00149 \\
(-1.42)\end{array}$ & $\begin{array}{c}-0.00397 \\
(-1.24)\end{array}$ \\
\hline BIS Policy Rate (t-1) & $\begin{array}{c}-0.0106 \\
(-0.77)\end{array}$ & $\begin{array}{c}-0.00365^{+} \\
(-1.45)\end{array}$ & $\begin{array}{c}-0.00119 \\
(-0.57)\end{array}$ & $\begin{array}{c}0.00132 \\
(0.22)\end{array}$ & $\begin{array}{c}0.00762 \\
(0.47)\end{array}$ \\
\hline Avg. RGDP Growth (8Q) & $\begin{array}{c}3.033^{*} \\
(1.70)\end{array}$ & $\begin{array}{c}0.777^{*} \\
(1.86)\end{array}$ & $\begin{array}{c}-0.0199 \\
(-0.10)\end{array}$ & $\begin{array}{l}-0.833 \\
(-1.42)\end{array}$ & $\begin{array}{c}-2.869^{+} \\
(-1.62)\end{array}$ \\
\hline Emerging Mkt. News & $\begin{array}{c}0.00757^{* * *} \\
\quad(5.92)\end{array}$ & $\begin{array}{c}0.00173^{* * *} \\
\quad(2.68)\end{array}$ & $\begin{array}{c}-0.000334 \\
(-0.40)\end{array}$ & $\begin{array}{c}-0.00244^{* *} \\
(-2.05)\end{array}$ & $\begin{array}{c}-0.00771^{* * *} \\
\quad(-3.46)\end{array}$ \\
\hline Adv. market index $(\mathrm{t}-1)$ & $\begin{array}{c}-0.0136^{* * *} \\
(-2.97)\end{array}$ & $\begin{array}{c}-0.00352^{* * *} \\
(-3.18)\end{array}$ & $\begin{array}{c}0.0000515 \\
(0.09)\end{array}$ & $\begin{array}{c}0.00369^{* * *} \\
\quad(2.71)\end{array}$ & $\begin{array}{c}0.0128^{* * *} \\
(2.87)\end{array}$ \\
\hline AE Real GDP Growth (t-1) & $\begin{array}{c}10.49^{* * *} \\
(3.57)\end{array}$ & $\begin{array}{c}2.370^{* * *} \\
(3.41)\end{array}$ & $\begin{array}{c}-0.498^{* * *} \\
(-2.63)\end{array}$ & $\begin{array}{c}-3.423^{* * *} \\
(-5.19)\end{array}$ & $\begin{array}{c}-10.75^{* * *} \\
(-4.01)\end{array}$ \\
\hline AE Monetary Stance (t-1) & $\begin{array}{c}0.0657^{* * *} \\
\quad(2.75)\end{array}$ & $\begin{array}{c}0.0342^{* * *} \\
(3.85)\end{array}$ & $\begin{array}{c}0.0231^{* * *} \\
(4.43)\end{array}$ & $\begin{array}{c}0.0118^{*} \\
(1.66)\end{array}$ & $\begin{array}{c}-0.0166 \\
(-0.86)\end{array}$ \\
\hline Observations & 72390 & 72390 & 72390 & 72390 & 72390 \\
\hline
\end{tabular}

Notes: This table summarizes the results of quantile regressions of EMBI daily total returns on our BEX constituent indices. Bootstrapped standard errors are clustered by country. ${ }^{*}, * *$, and ${ }^{* * *}$ denote statistical significance at the $10 \%, 5 \%$, and $1 \%$ levels, respectively. 
Table 5f: A one standard deviation risk-off (BEX) shock \& the distribution of local currency bond returns

\begin{tabular}{|c|c|c|c|c|c|}
\hline & $\begin{array}{l}\text { (1) } \\
\text { Q5 }\end{array}$ & $\begin{array}{c}(2) \\
\text { Q25 }\end{array}$ & $\begin{array}{l}(3) \\
\text { Q50 }\end{array}$ & $\begin{array}{l}4) \\
\text { Q75 }\end{array}$ & $\begin{array}{l}5) \\
\text { Q95 }\end{array}$ \\
\hline Log Diff. Risk Aversion & $\begin{array}{c}0.00500 \\
(0.14)\end{array}$ & $\begin{array}{c}-0.00685 \\
(-0.42)\end{array}$ & $\begin{array}{c}-0.0102 \\
(-0.74)\end{array}$ & $\begin{array}{c}-0.0142 \\
(-1.23)\end{array}$ & $\begin{array}{l}-0.0248 \\
(-1.38)\end{array}$ \\
\hline Log Diff. Risk & $\begin{array}{c}-0.0565^{* *} \\
(-2.24)\end{array}$ & $\begin{array}{c}-0.0195^{*} \\
(-1.79)\end{array}$ & $\begin{array}{c}-0.00902 \\
(-0.87)\end{array}$ & $\begin{array}{c}0.00333 \\
(0.35)\end{array}$ & $\begin{array}{c}0.0364^{* *} \\
(2.47)\end{array}$ \\
\hline $\operatorname{REER}(\mathrm{t}-1)$ & $\begin{array}{c}-0.00502 \\
(-0.47)\end{array}$ & $\begin{array}{c}-0.00133 \\
(-0.67)\end{array}$ & $\begin{array}{c}-0.000278 \\
(-0.64)\end{array}$ & $\begin{array}{c}0.000957 \\
(0.52)\end{array}$ & $\begin{array}{c}0.00427 \\
(0.41)\end{array}$ \\
\hline BIS Policy Rate (t-1) & $\begin{array}{c}-0.0459^{* * *} \\
(-2.85)\end{array}$ & $\begin{array}{c}-0.0119^{* * *} \\
(-3.17)\end{array}$ & $\begin{array}{c}-0.00220 \\
(-0.64)\end{array}$ & $\begin{array}{c}0.00919^{*} \\
(1.88)\end{array}$ & $\begin{array}{c}0.0397^{* * *} \\
(2.69)\end{array}$ \\
\hline Avg. RGDP Growth (8Q) & $\begin{array}{l}-0.0696 \\
(-0.03)\end{array}$ & $\begin{array}{l}-0.591 \\
(-0.99)\end{array}$ & $\begin{array}{c}-0.739^{* * *} \\
(-3.41)\end{array}$ & $\begin{array}{l}-0.914^{+} \\
(-1.52)\end{array}$ & $\begin{array}{l}-1.381 \\
(-0.51)\end{array}$ \\
\hline Emerging Mkt. News & $\begin{array}{c}-0.000248 \\
(-0.14)\end{array}$ & $\begin{array}{c}-0.00305^{* *} \\
(-2.44)\end{array}$ & $\begin{array}{c}-0.00385^{* * *} \\
(-2.98)\end{array}$ & $\begin{array}{c}-0.00478^{* * *} \\
(-3.18)\end{array}$ & $\begin{array}{c}-0.00729^{* *} \\
(-2.39)\end{array}$ \\
\hline Adv. market index ( $\mathrm{t}-1)$ & $\begin{array}{c}-0.00915^{* *} \\
(-2.06)\end{array}$ & $\begin{array}{c}-0.00202^{*} \\
(-1.85)\end{array}$ & $\begin{array}{l}0.000000305 \\
(0.00)\end{array}$ & $\begin{array}{c}0.00238^{* * *} \\
(5.29)\end{array}$ & $\begin{array}{c}0.00876^{* *} \\
\quad(2.52)\end{array}$ \\
\hline AE Real GDP Growth (t-1) & $\begin{array}{l}1.437 \\
(0.80)\end{array}$ & $\begin{array}{l}-0.255 \\
(-0.57)\end{array}$ & $\begin{array}{c}-0.735^{* * *} \\
(-2.92)\end{array}$ & $\begin{array}{c}-1.301^{* * *} \\
(-3.13)\end{array}$ & $\begin{array}{l}-2.815^{*} \\
(-1.66)\end{array}$ \\
\hline AE Monetary Stance $(\mathrm{t}-1)$ & $\begin{array}{c}0.00627 \\
(0.22)\end{array}$ & $\begin{array}{c}-0.00234 \\
(-0.25)\end{array}$ & $\begin{array}{c}-0.00479 \\
(-0.41)\end{array}$ & $\begin{array}{c}-0.00766 \\
(-0.45)\end{array}$ & $\begin{array}{l}-0.0154 \\
(-0.35)\end{array}$ \\
\hline Observations & 49266 & 49266 & 49266 & 49266 & 49266 \\
\hline $\begin{array}{l}t \text { statistics in parentheses } \\
+p<0.15, * p<0.10,{ }^{* *} p<0.0\end{array}$ & $* * p<0.01$ & & & & \\
\hline
\end{tabular}


Table 6a: A one standard deviation risk-off (RORO) shock \& the distribution of bond flows

\begin{tabular}{|c|c|c|c|c|c|}
\hline & $\begin{array}{l}\text { (1) } \\
\text { Q5 }\end{array}$ & $\begin{array}{c}(2) \\
\text { Q25 }\end{array}$ & $\begin{array}{c}\text { (3) } \\
\text { Q50 }\end{array}$ & $\begin{array}{c}\text { (4) } \\
\text { Q75 }\end{array}$ & $\begin{array}{c}\text { (5) } \\
\text { Q95 }\end{array}$ \\
\hline Funding Liquidity & $\begin{array}{c}-0.123^{* * *} \\
(-12.88)\end{array}$ & $\begin{array}{c}-0.0724^{* * *} \\
(-13.70)\end{array}$ & $\begin{array}{c}-0.0461^{* * *} \\
(-13.09)\end{array}$ & $\begin{array}{c}-0.0217^{* * *} \\
(-7.87)\end{array}$ & $\begin{array}{c}0.0253^{* * *} \\
(5.49)\end{array}$ \\
\hline AE Equity Returns \& Volatility & $\begin{array}{l}0.0117 \\
(1.06)\end{array}$ & $\begin{array}{c}0.0256^{* * *} \\
(4.79)\end{array}$ & $\begin{array}{c}0.0328^{* * *} \\
(9.88)\end{array}$ & $\begin{array}{c}0.0396^{* * *} \\
(9.70)\end{array}$ & $\begin{array}{c}0.0525^{* * *} \\
(5.65)\end{array}$ \\
\hline Corporate Spreads & $\begin{array}{c}-0.146^{* * *} \\
(-10.35)\end{array}$ & $\begin{array}{c}-0.143^{* * *} \\
(-15.14)\end{array}$ & $\begin{array}{c}-0.141^{* * *} \\
(-18.13)\end{array}$ & $\begin{array}{c}-0.140^{* * *} \\
(-19.44)\end{array}$ & $\begin{array}{c}-0.137^{* * *} \\
(-15.28)\end{array}$ \\
\hline Gold and Currency & $\begin{array}{c}-0.0381^{* * *} \\
(-6.52)\end{array}$ & $\begin{array}{c}-0.0396^{* * *} \\
(-12.22)\end{array}$ & $\begin{array}{c}-0.0404^{* * *} \\
(-15.34)\end{array}$ & $\begin{array}{c}-0.0412^{* * *} \\
(-13.75)\end{array}$ & $\begin{array}{c}-0.0426^{* * *} \\
(-8.12)\end{array}$ \\
\hline Policy Rate (t-1) & $\begin{array}{c}-0.00246 \\
(-0.20)\end{array}$ & $\begin{array}{c}-0.00126 \\
(-0.24)\end{array}$ & $\begin{array}{c}-0.000635 \\
(-0.25)\end{array}$ & $\begin{array}{c}-0.0000532 \\
(-0.02)\end{array}$ & $\begin{array}{c}0.00107 \\
(0.12)\end{array}$ \\
\hline $\operatorname{REER}(\mathrm{t}-1)$ & $\begin{array}{c}-0.00187 \\
(-0.76)\end{array}$ & $\begin{array}{c}-0.000730 \\
(-0.74)\end{array}$ & $\begin{array}{c}-0.000135 \\
(-0.22)\end{array}$ & $\begin{array}{c}0.000416 \\
(0.42)\end{array}$ & $\begin{array}{c}0.00148 \\
(0.63)\end{array}$ \\
\hline Avg. RGDP Growth (8Q) & $\begin{array}{c}-0.00425 \\
(-0.01)\end{array}$ & $\begin{array}{l}0.186 \\
(0.47)\end{array}$ & $\begin{array}{l}0.285 \\
(1.02)\end{array}$ & $\begin{array}{l}0.377 \\
(1.09)\end{array}$ & $\begin{array}{l}0.555 \\
(0.78)\end{array}$ \\
\hline Emerging Mkt. News & $\begin{array}{c}0.000500 \\
(0.09)\end{array}$ & $\begin{array}{c}-0.0203^{* * *} \\
(-7.70)\end{array}$ & $\begin{array}{c}-0.0312^{* * *} \\
(-15.03)\end{array}$ & $\begin{array}{c}-0.0412^{* * *} \\
(-16.75)\end{array}$ & $\begin{array}{c}-0.0607^{* * *} \\
(-12.67)\end{array}$ \\
\hline Adv. Mkt. Index (t-1) & $\begin{array}{c}-0.00242 \\
(-1.38)\end{array}$ & $\begin{array}{c}-0.00704^{* * *} \\
(-10.22)\end{array}$ & $\begin{array}{c}-0.00946^{* * *} \\
(-10.59)\end{array}$ & $\begin{array}{c}-0.0117^{* * *} \\
(-8.40)\end{array}$ & $\begin{array}{c}-0.0160^{* * *} \\
(-6.27)\end{array}$ \\
\hline AE Real GDP Growth (t-1) & $\begin{array}{l}0.410 \\
(0.27)\end{array}$ & $\begin{array}{c}-3.341^{* * *} \\
(-4.40)\end{array}$ & $\begin{array}{c}-5.307^{* * *} \\
(-10.95)\end{array}$ & $\begin{array}{c}-7.126^{* * *} \\
(-15.63)\end{array}$ & $\begin{array}{c}-10.63^{* * *} \\
(-10.38)\end{array}$ \\
\hline AE Monetary Stance (t-1) & $\begin{array}{c}0.107^{\text {*** }} \\
(6.47)\end{array}$ & $\begin{array}{c}-0.0186^{* *} \\
(-2.05)\end{array}$ & $\begin{array}{c}-0.0842^{* * *} \\
(-6.30)\end{array}$ & $\begin{array}{c}-0.145^{* * *} \\
(-7.62)\end{array}$ & $\begin{array}{c}-0.262^{* * *} \\
(-8.43)\end{array}$ \\
\hline $\operatorname{AR}(1)$ & $\begin{array}{c}0.577^{* * *} \\
(14.65)\end{array}$ & $\begin{array}{c}0.510^{* * *} \\
(18.22)\end{array}$ & $\begin{array}{c}0.476^{* * *} \\
(19.00)\end{array}$ & $\begin{array}{c}0.444^{* * *} \\
(17.93)\end{array}$ & $\begin{array}{c}0.381^{* * *} \\
(12.40)\end{array}$ \\
\hline Observations & 16917 & 16917 & 16917 & 16917 & 16917 \\
\hline
\end{tabular}

$t$ statistics in parentheses

${ }^{+} p<0.15,{ }^{*} p<0.10,{ }^{* *} p<0.05,{ }^{* * *} p<0.01$

Notes: This table summarizes the results of quantile regressions of EPFR country bond flows on our RORO constituent indices. Bootstrapped standard errors are clustered by country. ${ }^{*}{ }^{* *}$, and ${ }^{* * *}$ denote statistical significance at the $10 \%, 5 \%$, and $1 \%$ levels, respectively. 
Table 6b: A one standard deviation risk-off (RORO) shock \& the distribution of equity flows

\begin{tabular}{|c|c|c|c|c|c|}
\hline & $\begin{array}{l}(1) \\
\text { Q5 }\end{array}$ & $\begin{array}{c}(2) \\
Q 25\end{array}$ & $\begin{array}{l}\text { (3) } \\
\text { Q50 }\end{array}$ & $\begin{array}{l}(4) \\
\text { Q75 }\end{array}$ & $\begin{array}{l}(5) \\
\text { Q95 }\end{array}$ \\
\hline Funding Liquidity & $\begin{array}{l}0.0119^{* * *} \\
(2.91)\end{array}$ & $\begin{array}{l}0.000985 \\
(0.36)\end{array}$ & $\begin{array}{c}-0.00431 \\
(-1.28)\end{array}$ & $\begin{array}{c}-0.00951^{* *} \\
(-2.07)\end{array}$ & $\begin{array}{c}-0.0196^{* * *} \\
(-2.61)\end{array}$ \\
\hline AE Equity Returns \& Volatility & $\begin{array}{c}-0.0285^{* * *} \\
(-5.29)\end{array}$ & $\begin{array}{c}-0.0249^{* * *} \\
(-6.10)\end{array}$ & $\begin{array}{c}-0.0231^{* * *} \\
(-6.37)\end{array}$ & $\begin{array}{c}-0.0213^{* * *} \\
(-6.32)\end{array}$ & $\begin{array}{c}-0.0179^{* * *} \\
(-5.02)\end{array}$ \\
\hline Corporate Spreads & $\begin{array}{c}-0.110^{* * *} \\
(-15.23)\end{array}$ & $\begin{array}{c}-0.105^{* * *} \\
(-23.36)\end{array}$ & $\begin{array}{c}-0.103^{* * *} \\
(-26.90)\end{array}$ & $\begin{array}{c}-0.101^{* * *} \\
(-25.59)\end{array}$ & $\begin{array}{c}-0.0968^{* * *} \\
(-16.40)\end{array}$ \\
\hline Gold and Currency & $\begin{array}{c}-0.00842^{*} \\
(-1.74)\end{array}$ & $\begin{array}{c}-0.00957^{* * *} \\
(-4.14)\end{array}$ & $\begin{array}{c}-0.0101^{* * *} \\
(-5.16)\end{array}$ & $\begin{array}{c}-0.0107^{* * *} \\
(-4.02)\end{array}$ & $\begin{array}{c}-0.0117^{* *} \\
(-2.28)\end{array}$ \\
\hline Policy Rate (t-1) & $\begin{array}{c}-0.00101 \\
(-0.33)\end{array}$ & $\begin{array}{c}0.0000933 \\
(0.05)\end{array}$ & $\begin{array}{c}0.000626 \\
(0.45)\end{array}$ & $\begin{array}{c}0.00115 \\
(0.77)\end{array}$ & $\begin{array}{c}0.00217 \\
(0.86)\end{array}$ \\
\hline $\operatorname{REER}(\mathrm{t}-1)$ & $\begin{array}{c}-0.000541 \\
(-0.70)\end{array}$ & $\begin{array}{c}-0.000586^{*} \\
(-1.68)\end{array}$ & $\begin{array}{c}-0.000608^{*} \\
(-1.74)\end{array}$ & $\begin{array}{c}-0.000629 \\
(-1.21)\end{array}$ & $\begin{array}{c}-0.000671 \\
(-0.68)\end{array}$ \\
\hline Avg. RGDP Growth (8Q) & $\begin{array}{l}-0.872 \\
(-1.32)\end{array}$ & $\begin{array}{l}0.0259 \\
(0.16)\end{array}$ & $\begin{array}{c}0.460^{* *} \\
(2.13)\end{array}$ & $\begin{array}{l}0.887^{*} \\
(1.95)\end{array}$ & $\begin{array}{l}1.718^{*} \\
(1.77)\end{array}$ \\
\hline Emerging Mkt. News & $\begin{array}{c}-0.0207^{* * *} \\
(-8.56)\end{array}$ & $\begin{array}{c}-0.0210^{* * *} \\
(-15.57)\end{array}$ & $\begin{array}{c}-0.0211^{* * *} \\
(-17.01)\end{array}$ & $\begin{array}{c}-0.0213^{* * *} \\
(-13.88)\end{array}$ & $\begin{array}{c}-0.0215^{* * *} \\
(-8.12)\end{array}$ \\
\hline Adv. Mkt. Index (t-1) & $\begin{array}{c}0.00201^{+} \\
\quad(1.64)\end{array}$ & $\begin{array}{c}0.00129 \\
(1.29)\end{array}$ & $\begin{array}{c}0.000939 \\
(0.82)\end{array}$ & $\begin{array}{c}0.000598 \\
(0.43)\end{array}$ & $\begin{array}{c}-0.0000677 \\
(-0.03)\end{array}$ \\
\hline AE Real GDP Growth (t-1) & $\begin{array}{l}-1.262 \\
(-1.19)\end{array}$ & $\begin{array}{l}0.0433 \\
(0.09)\end{array}$ & $\begin{array}{l}0.675 \\
(1.18)\end{array}$ & $\begin{array}{c}1.295^{+} \\
(1.57)\end{array}$ & $\begin{array}{l}2.504^{*} \\
(1.67)\end{array}$ \\
\hline AE Monetary Stance (t-1) & $\begin{array}{c}0.106^{* * *} \\
(5.18)\end{array}$ & $\begin{array}{c}-0.0217^{*} \\
(-1.89)\end{array}$ & $\begin{array}{c}-0.0835^{* * *} \\
(-8.18)\end{array}$ & $\begin{array}{c}-0.144^{* * *} \\
(-10.79)\end{array}$ & $\begin{array}{c}-0.262^{* * *} \\
(-10.88)\end{array}$ \\
\hline $\operatorname{AR}(1)$ & $\begin{array}{c}0.319^{* * *} \\
(5.72)\end{array}$ & $\begin{array}{c}0.349^{* * *} \\
(10.47)\end{array}$ & $\begin{array}{c}0.363^{* * *} \\
(12.91)\end{array}$ & $\begin{array}{c}0.377^{* * *} \\
(12.60)\end{array}$ & $\begin{array}{c}0.404^{* * *} \\
(8.42)\end{array}$ \\
\hline Observations & 16967 & 16967 & 16967 & 16967 & 16967 \\
\hline \multicolumn{6}{|l|}{$\begin{array}{l}t \text { statistics in parentheses } \\
+p<0.15,{ }^{*} p<0.10,{ }^{* *}\end{array}$} \\
\hline
\end{tabular}


Table 6c: A one standard deviation risk-off (RORO) shock \& the distribution of USD equity returns

\begin{tabular}{|c|c|c|c|c|c|}
\hline & $\begin{array}{l}\text { (1) } \\
\text { Q5 }\end{array}$ & $\begin{array}{c}(2) \\
\text { Q25 }\end{array}$ & $\begin{array}{c}\text { (3) } \\
\text { Q50 }\end{array}$ & $\begin{array}{c}\text { (4) } \\
\text { Q75 }\end{array}$ & $\begin{array}{c}\text { (5) } \\
\text { Q95 }\end{array}$ \\
\hline Funding Liquidity & $\begin{array}{l}0.0191 \\
(1.06)\end{array}$ & $\begin{array}{c}0.0148^{+} \\
(1.45)\end{array}$ & $\begin{array}{c}0.0126^{+} \\
(1.60)\end{array}$ & $\begin{array}{c}0.0102 \\
(1.22)\end{array}$ & $\begin{array}{c}0.00591 \\
(0.39)\end{array}$ \\
\hline AE Equity Returns \& Volatility & $\begin{array}{c}-0.529^{* * *} \\
(-6.59)\end{array}$ & $\begin{array}{c}-0.561^{* * *} \\
(-6.46)\end{array}$ & $\begin{array}{c}-0.578^{* * *} \\
(-6.36)\end{array}$ & $\begin{array}{c}-0.595^{* * *} \\
(-6.25)\end{array}$ & $\begin{array}{c}-0.627^{* * *} \\
(-6.06)\end{array}$ \\
\hline Corporate Spreads & $\begin{array}{c}-0.506^{* * *} \\
(-14.89)\end{array}$ & $\begin{array}{c}-0.356^{* * *} \\
(-13.80)\end{array}$ & $\begin{array}{c}-0.278^{* * *} \\
(-11.43)\end{array}$ & $\begin{array}{c}-0.197^{* * *} \\
(-7.99)\end{array}$ & $\begin{array}{c}-0.0463^{+} \\
(-1.49)\end{array}$ \\
\hline Gold and Currency & $\begin{array}{c}-0.237^{* * *} \\
(-5.60)\end{array}$ & $\begin{array}{c}-0.236^{* * *} \\
(-5.86)\end{array}$ & $\begin{array}{c}-0.236^{* * *} \\
(-5.95)\end{array}$ & $\begin{array}{c}-0.236^{* * *} \\
(-5.97)\end{array}$ & $\begin{array}{c}-0.235^{* * *} \\
(-5.87)\end{array}$ \\
\hline $\operatorname{REER}(\mathrm{t}-1)$ & $\begin{array}{c}0.00407 \\
(0.96)\end{array}$ & $\begin{array}{c}0.000191 \\
(0.14)\end{array}$ & $\begin{array}{c}-0.00182^{* * *} \\
(-3.37)\end{array}$ & $\begin{array}{c}-0.00392^{* *} \\
(-2.02)\end{array}$ & $\begin{array}{c}-0.00781^{+} \\
(-1.62)\end{array}$ \\
\hline BIS Policy Rate (t-1) & $\begin{array}{c}-0.0305^{* *} \\
(-2.16)\end{array}$ & $\begin{array}{c}-0.0106^{* * *} \\
(-3.03)\end{array}$ & $\begin{array}{c}-0.000250 \\
(-0.07)\end{array}$ & $\begin{array}{c}0.0106 \\
(1.16)\end{array}$ & $\begin{array}{c}0.0305^{+} \\
(1.51)\end{array}$ \\
\hline Avg. RGDP Growth (8Q) & $\begin{array}{l}1.248 \\
(0.59)\end{array}$ & $\begin{array}{l}0.439 \\
(0.50)\end{array}$ & $\begin{array}{c}0.0195 \\
(0.06)\end{array}$ & $\begin{array}{l}-0.419 \\
(-0.72)\end{array}$ & $\begin{array}{l}-1.230 \\
(-0.68)\end{array}$ \\
\hline Emerging Mkt. News & $\begin{array}{c}0.0136^{* * *} \\
\quad(4.45)\end{array}$ & $\begin{array}{c}0.00440^{* * *} \\
\quad(2.91)\end{array}$ & $\begin{array}{c}-0.000341 \\
(-0.22)\end{array}$ & $\begin{array}{c}-0.00530^{* *} \\
(-2.36)\end{array}$ & $\begin{array}{c}-0.0145^{* * *} \\
(-3.47)\end{array}$ \\
\hline Adv. market index $(\mathrm{t}-1)$ & $\begin{array}{c}-0.0285^{* * *} \\
(-5.64)\end{array}$ & $\begin{array}{c}-0.0102^{* * *} \\
(-4.10)\end{array}$ & $\begin{array}{c}-0.000685 \\
(-0.44)\end{array}$ & $\begin{array}{c}0.00927^{* * *} \\
(5.73)\end{array}$ & $\begin{array}{c}0.0277^{* * *} \\
(7.53)\end{array}$ \\
\hline AE Real GDP Growth (t-1) & $\begin{array}{c}15.97^{* * *} \\
(6.50)\end{array}$ & $\begin{array}{c}4.806^{* * *} \\
(4.24)\end{array}$ & $\begin{array}{l}-0.977 \\
(-1.22)\end{array}$ & $\begin{array}{c}-7.031^{* * *} \\
(-6.57)\end{array}$ & $\begin{array}{c}-18.22^{* * *} \\
(-7.83)\end{array}$ \\
\hline AE Monetary Stance (t-1) & $\begin{array}{c}-0.143^{* *} \\
(-2.55)\end{array}$ & $\begin{array}{c}-0.0250 \\
(-0.93)\end{array}$ & $\begin{array}{c}0.0361^{* * *} \\
(2.59)\end{array}$ & $\begin{array}{c}0.100^{* * *} \\
(9.56)\end{array}$ & $\begin{array}{c}0.218^{* * *} \\
(6.09)\end{array}$ \\
\hline Observations & 85097 & 85097 & 85097 & 85097 & 85097 \\
\hline
\end{tabular}

Notes: This table summarizes the results of quantile regressions of MSCI USD daily total returns on our RORO constituent indices. Bootstrapped standard errors are clustered by country. ${ }^{*}, * *$, and ${ }^{* * *}$ denote statistical significance at the $10 \%, 5 \%$, and $1 \%$ levels, respectively. 
Table 6d: A one standard deviation risk-off (RORO) shock \& the distribution of local currency equity returns

\begin{tabular}{|c|c|c|c|c|c|}
\hline & $\begin{array}{l}\text { (1) } \\
\text { Q5 }\end{array}$ & $\begin{array}{c}(2) \\
\text { Q25 }\end{array}$ & $\begin{array}{c}\text { (3) } \\
\text { Q50 }\end{array}$ & $\begin{array}{c}(4) \\
\text { Q75 }\end{array}$ & $\begin{array}{c}\text { (5) } \\
\text { Q95 }\end{array}$ \\
\hline Funding Liquidity & $\begin{array}{c}0.00687 \\
(0.46)\end{array}$ & $\begin{array}{c}0.00719 \\
(0.84)\end{array}$ & $\begin{array}{c}0.00735 \\
(1.07)\end{array}$ & $\begin{array}{c}0.00752 \\
(1.01)\end{array}$ & $\begin{array}{c}0.00784 \\
(0.60)\end{array}$ \\
\hline AE Equity Returns \& Volatility & $\begin{array}{c}-0.407^{* * *} \\
(-6.38)\end{array}$ & $\begin{array}{c}-0.441^{* * *} \\
(-6.34)\end{array}$ & $\begin{array}{c}-0.458^{* * *} \\
(-6.26)\end{array}$ & $\begin{array}{c}-0.476^{* * *} \\
(-6.18)\end{array}$ & $\begin{array}{c}-0.510^{* * *} \\
(-6.07)\end{array}$ \\
\hline Corporate Spreads & $\begin{array}{c}-0.433^{* * *} \\
(-13.50)\end{array}$ & $\begin{array}{c}-0.298^{* * *} \\
(-11.93)\end{array}$ & $\begin{array}{c}-0.229^{* * *} \\
(-9.26)\end{array}$ & $\begin{array}{c}-0.157^{* * *} \\
(-6.10)\end{array}$ & $\begin{array}{c}-0.0218 \\
(-0.68)\end{array}$ \\
\hline Gold and Currency & $\begin{array}{c}-0.110^{* * *} \\
(-3.98)\end{array}$ & $\begin{array}{c}-0.103^{* * *} \\
(-4.31)\end{array}$ & $\begin{array}{c}-0.1000^{* * *} \\
(-4.48)\end{array}$ & $\begin{array}{c}-0.0965^{* * *} \\
(-4.62)\end{array}$ & $\begin{array}{c}-0.0901^{* * *} \\
(-4.69)\end{array}$ \\
\hline $\operatorname{REER}(\mathrm{t}-1)$ & $\begin{array}{c}0.00151 \\
(0.42)\end{array}$ & $\begin{array}{c}0.00000625 \\
\quad(0.01)\end{array}$ & $\begin{array}{c}-0.000763 \\
(-1.24)\end{array}$ & $\begin{array}{c}-0.00157 \\
(-0.95)\end{array}$ & $\begin{array}{c}-0.00309 \\
(-0.76)\end{array}$ \\
\hline BIS Policy Rate (t-1) & $\begin{array}{c}-0.0289^{* * *} \\
(-2.81)\end{array}$ & $\begin{array}{c}-0.0101^{* *} \\
(-2.34)\end{array}$ & $\begin{array}{c}-0.000478 \\
(-0.20)\end{array}$ & $\begin{array}{c}0.00959^{* *} \\
(2.50)\end{array}$ & $\begin{array}{c}0.0285^{* * *} \\
(2.90)\end{array}$ \\
\hline Avg. RGDP Growth (8Q) & $\begin{array}{l}-0.254 \\
(-0.13)\end{array}$ & $\begin{array}{c}-0.0287 \\
(-0.04)\end{array}$ & $\begin{array}{c}0.0861 \\
(0.36)\end{array}$ & $\begin{array}{l}0.206 \\
(0.32)\end{array}$ & $\begin{array}{l}0.433 \\
(0.24)\end{array}$ \\
\hline Emerging Mkt. News & $\begin{array}{c}0.0121^{* * *} \\
(4.52)\end{array}$ & $\begin{array}{c}0.00393^{* * *} \\
(2.93)\end{array}$ & $\begin{array}{c}-0.000248 \\
(-0.19)\end{array}$ & $\begin{array}{c}-0.00463^{* *} \\
(-2.40)\end{array}$ & $\begin{array}{c}-0.0129^{* * *} \\
(-3.54)\end{array}$ \\
\hline Adv. market index (t-1) & $\begin{array}{c}-0.0223^{* * *} \\
(-5.44)\end{array}$ & $\begin{array}{c}-0.00750^{* * *} \\
(-3.58)\end{array}$ & $\begin{array}{c}0.0000278 \\
(0.02)\end{array}$ & $\begin{array}{c}0.00792^{* * *} \\
\quad(5.01)\end{array}$ & $\begin{array}{c}0.0228^{* * *} \\
(7.47)\end{array}$ \\
\hline AE Real GDP Growth (t-1) & $\begin{array}{c}13.65^{* * *} \\
(4.86)\end{array}$ & $\begin{array}{c}4.129^{* * *} \\
(3.58)\end{array}$ & $\begin{array}{l}-0.729 \\
(-1.04)\end{array}$ & $\begin{array}{c}-5.824^{* * *} \\
(-5.13)\end{array}$ & $\begin{array}{c}-15.40^{* * *} \\
(-5.60)\end{array}$ \\
\hline AE Monetary Stance $(\mathrm{t}-1)$ & $\begin{array}{c}-0.127^{* * *} \\
(-2.60)\end{array}$ & $\begin{array}{c}-0.0239 \\
(-1.09)\end{array}$ & $\begin{array}{c}0.0287^{* *} \\
(2.44)\end{array}$ & $\begin{array}{c}0.0840^{* * *} \\
(8.14)\end{array}$ & $\begin{array}{c}0.188^{* * *} \\
(5.61)\end{array}$ \\
\hline Observations & 85118 & 85118 & 85118 & 85118 & 85118 \\
\hline
\end{tabular}

Notes: This table summarizes the results of quantile regressions of MSCI LC daily total returns on our RORO constituent indices. Bootstrapped standard errors are clustered by country. ${ }^{*}, * *$, and ${ }^{* *}$ denote statistical significance at the $10 \%, 5 \%$, and $1 \%$ levels, respectively. 
Table 6e: A one standard deviation risk-off (RORO) shock \& the distribution of USD bond returns

\begin{tabular}{|c|c|c|c|c|c|}
\hline & $\begin{array}{l}(1) \\
\text { Q5 }\end{array}$ & $\begin{array}{c}(2) \\
\text { Q25 }\end{array}$ & $\begin{array}{c}\text { (3) } \\
\text { Q50 }\end{array}$ & $\begin{array}{c}(4) \\
\text { Q75 }\end{array}$ & $\begin{array}{c}(5) \\
\text { Q95 }\end{array}$ \\
\hline Funding Liquidity & $\begin{array}{c}0.0184 \\
(1.31)\end{array}$ & $\begin{array}{c}0.00507 \\
(0.83)\end{array}$ & $\begin{array}{c}-0.000257 \\
(-0.05)\end{array}$ & $\begin{array}{c}-0.00539 \\
(-0.86)\end{array}$ & $\begin{array}{l}-0.0165 \\
(-1.26)\end{array}$ \\
\hline AE Equity Returns \& Volatility & $\begin{array}{c}-0.100^{* * *} \\
(-3.58)\end{array}$ & $\begin{array}{c}-0.0876^{* * *} \\
(-3.44)\end{array}$ & $\begin{array}{c}-0.0824^{* * *} \\
(-3.31)\end{array}$ & $\begin{array}{c}-0.0775^{* * *} \\
(-3.16)\end{array}$ & $\begin{array}{c}-0.0667^{* * *} \\
(-2.72)\end{array}$ \\
\hline Corporate Spreads & $\begin{array}{c}-0.211^{* * *} \\
(-6.23)\end{array}$ & $\begin{array}{c}-0.123^{* * *} \\
(-5.54)\end{array}$ & $\begin{array}{c}-0.0881^{* * *} \\
(-4.53)\end{array}$ & $\begin{array}{c}-0.0544^{* * *} \\
(-3.11)\end{array}$ & $\begin{array}{l}0.0188 \\
(1.13)\end{array}$ \\
\hline Gold and Currency & $\begin{array}{c}-0.0920^{* * *} \\
(-9.12)\end{array}$ & $\begin{array}{c}-0.0802^{* * *} \\
(-8.93)\end{array}$ & $\begin{array}{c}-0.0755^{* * *} \\
(-8.71)\end{array}$ & $\begin{array}{c}-0.0709^{* * *} \\
(-8.35)\end{array}$ & $\begin{array}{c}-0.0611^{* * *} \\
(-7.06)\end{array}$ \\
\hline $\operatorname{REER}(\mathrm{t}-1)$ & $\begin{array}{c}0.00320 \\
(1.04)\end{array}$ & $\begin{array}{c}0.000660 \\
(0.78)\end{array}$ & $\begin{array}{c}-0.000353^{+} \\
(-1.47)\end{array}$ & $\begin{array}{c}-0.00133 \\
(-1.35)\end{array}$ & $\begin{array}{c}-0.00345 \\
(-1.22)\end{array}$ \\
\hline BIS Policy Rate (t-1) & $\begin{array}{l}-0.0117 \\
(-1.03)\end{array}$ & $\begin{array}{c}-0.00420^{*} \\
(-1.87)\end{array}$ & $\begin{array}{c}-0.00119 \\
(-0.58)\end{array}$ & $\begin{array}{c}0.00170 \\
(0.31)\end{array}$ & $\begin{array}{c}0.00799 \\
(0.61)\end{array}$ \\
\hline Avg. RGDP Growth (8Q) & $\begin{array}{l}2.423 \\
(1.39)\end{array}$ & $\begin{array}{l}0.632 \\
(1.39)\end{array}$ & $\begin{array}{c}-0.0833 \\
(-0.44)\end{array}$ & $\begin{array}{l}-0.772 \\
(-1.31)\end{array}$ & $\begin{array}{l}-2.270 \\
(-1.37)\end{array}$ \\
\hline Emerging Mkt. News & $\begin{array}{c}0.00874^{* * *} \\
(7.59)\end{array}$ & $\begin{array}{c}0.00281^{\text {*** }} \\
\quad(4.31)\end{array}$ & $\begin{array}{c}0.000443 \\
(0.48)\end{array}$ & $\begin{array}{c}-0.00184 \\
(-1.41)\end{array}$ & $\begin{array}{c}-0.00679^{* * *} \\
(-3.10)\end{array}$ \\
\hline Adv. market index (t-1) & $\begin{array}{c}-0.0115^{* *} \\
(-2.53)\end{array}$ & $\begin{array}{c}-0.00289^{* *} \\
(-2.26)\end{array}$ & $\begin{array}{c}0.000550 \\
(0.90)\end{array}$ & $\begin{array}{c}0.00386^{* * *} \\
(2.89)\end{array}$ & $\begin{array}{c}0.0111^{* * *} \\
(2.71)\end{array}$ \\
\hline AE Real GDP Growth (t-1) & $\begin{array}{c}9.586^{* * *} \\
(3.40)\end{array}$ & $\begin{array}{c}1.876^{* * *} \\
(2.74)\end{array}$ & $\begin{array}{c}-1.204^{* * *} \\
(-6.66)\end{array}$ & $\begin{array}{c}-4.170^{* * *} \\
(-5.21)\end{array}$ & $\begin{array}{c}-10.62^{* * *} \\
(-4.06)\end{array}$ \\
\hline AE Monetary Stance (t-1) & $\begin{array}{c}0.0849^{* * *} \\
(3.55)\end{array}$ & $\begin{array}{c}0.0531^{* * *} \\
(5.27)\end{array}$ & $\begin{array}{c}0.0404^{* * *} \\
(6.09)\end{array}$ & $\begin{array}{c}0.0282^{* * *} \\
(3.41)\end{array}$ & $\begin{array}{c}0.00168 \\
(0.09) \\
\end{array}$ \\
\hline Observations & 72451 & 72451 & 72451 & 72451 & 72451 \\
\hline
\end{tabular}

Notes: This table summarizes the results of quantile regressions of EMBI daily total returns on our RORO constituent indices. Bootstrapped standard errors are clustered by country. ${ }^{*},{ }^{* *}$, and ${ }^{* * *}$ denote statistical significance at the $10 \%, 5 \%$, and $1 \%$ levels, respectively. 
Table 6f: A one standard deviation risk-off (RORO) shock \& the distribution of local currency bond returns

\begin{tabular}{|c|c|c|c|c|c|}
\hline & $\begin{array}{l}\text { (1) } \\
\text { Q5 }\end{array}$ & $\begin{array}{l}(2) \\
\text { Q25 }\end{array}$ & $\begin{array}{l}\text { (3) } \\
\text { Q50 }\end{array}$ & $\begin{array}{l}(4) \\
\text { Q75 }\end{array}$ & $\begin{array}{c}\text { (5) } \\
\text { Q95 }\end{array}$ \\
\hline Funding Liquidity & $\begin{array}{c}0.0119^{+} \\
(1.50)\end{array}$ & $\begin{array}{c}-0.00251 \\
(-0.59)\end{array}$ & $\begin{array}{c}-0.00702^{*} \\
(-1.87)\end{array}$ & $\begin{array}{c}-0.0120^{* * *} \\
(-2.90)\end{array}$ & $\begin{array}{c}-0.0252^{* * *} \\
(-2.74)\end{array}$ \\
\hline AE Equity Returns \& Volatility & $\begin{array}{c}-0.0149 \\
(-0.96)\end{array}$ & $\begin{array}{c}-0.0114 \\
(-0.98)\end{array}$ & $\begin{array}{l}-0.0103 \\
(-0.90)\end{array}$ & $\begin{array}{c}-0.00908 \\
(-0.75)\end{array}$ & $\begin{array}{c}-0.00586 \\
(-0.33)\end{array}$ \\
\hline Corporate Spreads & $\begin{array}{c}-0.0792^{* * *} \\
(-4.37)\end{array}$ & $\begin{array}{c}-0.0428^{* * *} \\
(-3.34)\end{array}$ & $\begin{array}{c}-0.0314^{* *} \\
(-2.14)\end{array}$ & $\begin{array}{l}-0.0188 \\
(-1.10)\end{array}$ & $\begin{array}{l}0.0144 \\
(0.61)\end{array}$ \\
\hline Gold and Currency & $\begin{array}{c}-0.0295^{* * *} \\
(-2.76)\end{array}$ & $\begin{array}{c}-0.0255^{* * *} \\
(-4.90)\end{array}$ & $\begin{array}{c}-0.0243^{* * *} \\
(-4.93)\end{array}$ & $\begin{array}{c}-0.0229^{* * *} \\
(-4.12)\end{array}$ & $\begin{array}{c}-0.0192^{*} \\
(-1.74)\end{array}$ \\
\hline $\operatorname{REER}(\mathrm{t}-1)$ & $\begin{array}{c}-0.00436 \\
(-0.42)\end{array}$ & $\begin{array}{c}-0.00121 \\
(-0.58)\end{array}$ & $\begin{array}{c}-0.000221 \\
(-0.50)\end{array}$ & $\begin{array}{c}0.000872 \\
(0.49)\end{array}$ & $\begin{array}{c}0.00375 \\
(0.38)\end{array}$ \\
\hline BIS Policy Rate (t-1) & $\begin{array}{c}-0.0447^{* * *} \\
(-2.77)\end{array}$ & $\begin{array}{c}-0.0123^{* * *} \\
(-3.16)\end{array}$ & $\begin{array}{c}-0.00209 \\
(-0.62)\end{array}$ & $\begin{array}{c}0.00919^{*} \\
(1.91)\end{array}$ & $\begin{array}{c}0.0389^{* * *} \\
(2.65)\end{array}$ \\
\hline Avg. RGDP Growth (8Q) & $\begin{array}{l}-0.322 \\
(-0.12)\end{array}$ & $\begin{array}{l}-0.636 \\
(-1.07)\end{array}$ & $\begin{array}{c}-0.735^{* * *} \\
(-3.65)\end{array}$ & $\begin{array}{l}-0.844 \\
(-1.41)\end{array}$ & $\begin{array}{l}-1.132 \\
(-0.44)\end{array}$ \\
\hline Emerging Mkt. News & $\begin{array}{c}0.00101 \\
(0.52)\end{array}$ & $\begin{array}{c}-0.00226^{* *} \\
(-1.97)\end{array}$ & $\begin{array}{c}-0.00329^{* * *} \\
(-2.83)\end{array}$ & $\begin{array}{c}-0.00443^{* * *} \\
(-3.23)\end{array}$ & $\begin{array}{c}-0.00742^{* *} \\
(-2.48)\end{array}$ \\
\hline Adv. market index $(\mathrm{t}-1)$ & $\begin{array}{c}-0.00915^{*} \\
(-1.91)\end{array}$ & $\begin{array}{c}-0.00196^{*} \\
(-1.65)\end{array}$ & $\begin{array}{c}0.000295 \\
(0.44)\end{array}$ & $\begin{array}{c}0.00279^{* * *} \\
(6.42)\end{array}$ & $\begin{array}{c}0.00937^{* *} \\
(2.43)\end{array}$ \\
\hline AE Real GDP Growth (t-1) & $\begin{array}{l}2.073 \\
(1.11)\end{array}$ & $\begin{array}{c}0.00968 \\
(0.02)\end{array}$ & $\begin{array}{c}-0.638^{* *} \\
(-2.27)\end{array}$ & $\begin{array}{c}-1.354^{* * *} \\
(-3.26)\end{array}$ & $\begin{array}{l}-3.241^{*} \\
(-1.93)\end{array}$ \\
\hline AE Monetary Stance (t-1) & $\begin{array}{c}0.00927 \\
(0.37)\end{array}$ & $\begin{array}{c}0.00574 \\
(0.62)\end{array}$ & $\begin{array}{c}0.00464 \\
(0.43)\end{array}$ & $\begin{array}{c}0.00341 \\
(0.22)\end{array}$ & $\begin{array}{c}0.000189 \\
(0.00)\end{array}$ \\
\hline Observations & 49232 & 49232 & 49232 & 49232 & 49232 \\
\hline \multicolumn{6}{|c|}{$\begin{array}{l}t \text { statistics in parentheses } \\
{ }^{+} p<0.15,{ }^{*} p<0.10,{ }^{* *} p<0.05,{ }^{* * *} p<0.01\end{array}$} \\
\hline
\end{tabular}


Table 7: A one standard deviation risk-off shock \& the distribution of government money market fund assets

(a) Retail

\begin{tabular}{|c|c|c|c|c|c|c|c|c|}
\hline & $\begin{array}{l}(1) \\
\text { Q5 }\end{array}$ & $\begin{array}{l}(2) \\
\text { Q50 }\end{array}$ & $\begin{array}{l}\text { (3) } \\
\text { OLS }\end{array}$ & $\begin{array}{l}(4) \\
\text { Q95 }\end{array}$ & $\begin{array}{l}\text { (5) } \\
\text { Q5 }\end{array}$ & $\begin{array}{c}(6) \\
\text { Q50 }\end{array}$ & $\begin{array}{c}(7) \\
\text { OLS }\end{array}$ & $\begin{array}{c}(8) \\
\text { Q95 }\end{array}$ \\
\hline RORO Index & $\begin{array}{c}0.179^{* * *} \\
(7.38)\end{array}$ & $\begin{array}{c}0.0889^{*} \\
(2.39)\end{array}$ & $\begin{array}{l}0.154 \\
(1.91)\end{array}$ & $\begin{array}{l}0.244 \\
(1.82)\end{array}$ & & & & \\
\hline AE Mkt. Return & $\begin{array}{c}0.0144^{*} \\
(2.24)\end{array}$ & $\begin{array}{c}0.0370^{* * *} \\
(5.73)\end{array}$ & $\begin{array}{c}0.0522^{* * *} \\
(3.87)\end{array}$ & $\begin{array}{c}0.0582^{* * *} \\
(5.58)\end{array}$ & $\begin{array}{c}0.00897 \\
(1.04)\end{array}$ & $\begin{array}{c}0.0296^{* * *} \\
(5.07)\end{array}$ & $\begin{array}{c}0.0482^{* * *} \\
(3.55)\end{array}$ & $\begin{array}{c}0.0366^{* *} \\
(2.97)\end{array}$ \\
\hline AE Real GDP Growth (t-1) & $\begin{array}{l}6.908 \\
(0.98)\end{array}$ & $\begin{array}{l}10.41^{*} \\
(2.22)\end{array}$ & $\begin{array}{l}-5.446 \\
(-0.79)\end{array}$ & $\begin{array}{l}-19.01 \\
(-0.70)\end{array}$ & $\begin{array}{l}7.428^{*} \\
(2.10)\end{array}$ & $\begin{array}{l}8.213^{*} \\
(2.06)\end{array}$ & $\begin{array}{l}-5.660 \\
(-0.81)\end{array}$ & $\begin{array}{l}-43.69 \\
(-1.60)\end{array}$ \\
\hline AE Monetary Stance $(\mathrm{t}-1)$ & $\begin{array}{c}0.230^{*} \\
(2.35)\end{array}$ & $\begin{array}{c}0.234^{*} \\
(2.48)\end{array}$ & $\begin{array}{c}0.557^{* *} \\
(2.59)\end{array}$ & $\begin{array}{c}0.552^{* *} \\
(3.02)\end{array}$ & $\begin{array}{c}0.0249 \\
(0.22)\end{array}$ & $\begin{array}{l}0.153 \\
(1.73)\end{array}$ & $\begin{array}{c}0.489^{*} \\
(2.33)\end{array}$ & $\begin{array}{l}0.242 \\
(0.98)\end{array}$ \\
\hline Risk Aversion & & & & & $\begin{array}{c}-0.0199 \\
(-0.38)\end{array}$ & $\begin{array}{c}-0.0817 \\
(-1.63)\end{array}$ & $\begin{array}{l}-0.122 \\
(-0.96)\end{array}$ & $\begin{array}{l}-0.161 \\
(-0.77)\end{array}$ \\
\hline Risk & & & & & $\begin{array}{c}0.0549 \\
(0.98)\end{array}$ & $\begin{array}{c}0.105^{* *} \\
(2.75)\end{array}$ & $\begin{array}{l}0.184 \\
(1.68)\end{array}$ & $\begin{array}{c}0.235^{* *} \\
(2.65)\end{array}$ \\
\hline Constant & $\begin{array}{c}-4.058^{* * *} \\
(-3.77)\end{array}$ & $\begin{array}{c}-6.411^{* * *} \\
(-5.48)\end{array}$ & $\begin{array}{c}-9.173^{* * *} \\
(-3.45)\end{array}$ & $\begin{array}{c}-8.327^{* * *} \\
(-3.39)\end{array}$ & $\begin{array}{l}-2.486 \\
(-1.74)\end{array}$ & $\begin{array}{c}-4.931^{* * *} \\
(-4.70)\end{array}$ & $\begin{array}{c}-8.333^{* *} \\
(-3.16)\end{array}$ & $\begin{array}{l}-3.567 \\
(-1.31)\end{array}$ \\
\hline Observations & 628 & 628 & 628 & 628 & 656 & 656 & 656 & 656 \\
\hline
\end{tabular}

(b) Institutional

\begin{tabular}{|c|c|c|c|c|c|c|c|c|}
\hline & $\begin{array}{l}\text { (1) } \\
\text { Q5 }\end{array}$ & $\begin{array}{c}(2) \\
\text { Q50 }\end{array}$ & $\begin{array}{c}\text { (3) } \\
\text { OLS }\end{array}$ & $\begin{array}{c}(4) \\
\text { Q95 }\end{array}$ & $\begin{array}{l}\text { (5) } \\
\text { Q5 }\end{array}$ & $\begin{array}{c}(6) \\
\text { Q50 }\end{array}$ & $\begin{array}{c}7) \\
\text { OLS }\end{array}$ & $\begin{array}{c}\text { (8) } \\
\text { Q95 }\end{array}$ \\
\hline RORO Index & $\begin{array}{c}0.267^{* *} \\
(2.90)\end{array}$ & $\begin{array}{c}0.225^{* * *} \\
(3.98)\end{array}$ & $\begin{array}{c}0.321^{* *} \\
(2.93)\end{array}$ & $\begin{array}{c}0.506^{* *} \\
(3.09)\end{array}$ & & & & \\
\hline AE Mkt. Return & $\begin{array}{c}0.117^{* * *} \\
(7.06)\end{array}$ & $\begin{array}{c}0.0763^{* * *} \\
(5.66)\end{array}$ & $\begin{array}{c}0.116^{* * *} \\
(6.90)\end{array}$ & $\begin{array}{c}0.118^{* *} \\
(3.07)\end{array}$ & $\begin{array}{c}0.115^{* * *} \\
(6.23)\end{array}$ & $\begin{array}{c}0.0738^{* * *} \\
(6.00)\end{array}$ & $\begin{array}{c}0.112^{* * *} \\
(6.91)\end{array}$ & $\begin{array}{c}0.143^{* * *} \\
(3.42)\end{array}$ \\
\hline AE Real GDP Growth (t-1) & $\begin{array}{l}-9.389 \\
(-1.36)\end{array}$ & $\begin{array}{l}-1.085 \\
(-0.11)\end{array}$ & $\begin{array}{l}-10.68 \\
(-0.99)\end{array}$ & $\begin{array}{l}-22.17 \\
(-0.66)\end{array}$ & $\begin{array}{l}-9.788 \\
(-1.19)\end{array}$ & $\begin{array}{l}-1.984 \\
(-0.20)\end{array}$ & $\begin{array}{l}-11.84 \\
(-1.14)\end{array}$ & $\begin{array}{l}20.72 \\
(0.26)\end{array}$ \\
\hline AE Monetary Stance (t-1) & $\begin{array}{l}0.418^{*} \\
(2.04)\end{array}$ & $\begin{array}{l}0.490^{*} \\
(2.49)\end{array}$ & $\begin{array}{c}0.904^{* *} \\
(3.23)\end{array}$ & $\begin{array}{c}1.239^{*} \\
(2.02)\end{array}$ & $\begin{array}{l}0.404 \\
(1.55)\end{array}$ & $\begin{array}{c}0.516^{* *} \\
(2.89)\end{array}$ & $\begin{array}{c}0.878^{* *} \\
(3.21)\end{array}$ & $\begin{array}{l}1.181^{*} \\
(2.16)\end{array}$ \\
\hline Risk Aversion & & & & & $\begin{array}{c}0.248^{* *} \\
(2.81)\end{array}$ & $\begin{array}{c}-0.0123 \\
(-0.18)\end{array}$ & $\begin{array}{c}-0.0903 \\
(-0.51)\end{array}$ & $\begin{array}{l}-0.419 \\
(-1.21)\end{array}$ \\
\hline Risk & & & & & $\begin{array}{c}-0.00334 \\
(-0.04)\end{array}$ & $\begin{array}{c}0.332^{* * *} \\
(5.25)\end{array}$ & $\begin{array}{l}0.342 \\
(1.93)\end{array}$ & $\begin{array}{l}0.465 \\
(1.79)\end{array}$ \\
\hline Constant & $\begin{array}{c}-19.49^{* * *} \\
(-7.56)\end{array}$ & $\begin{array}{c}-12.38^{* * *} \\
(-5.16)\end{array}$ & $\begin{array}{c}-18.73^{* * *} \\
(-5.80)\end{array}$ & $\begin{array}{l}-17.92 \\
(-1.95)\end{array}$ & $\begin{array}{c}-19.24^{* * *} \\
(-6.03)\end{array}$ & $\begin{array}{c}-12.05^{* * *} \\
(-5.42)\end{array}$ & $\begin{array}{c}-18.09^{* * *} \\
(-5.85)\end{array}$ & $\begin{array}{c}-22.34^{*} \\
(-2.18)\end{array}$ \\
\hline Observations & 628 & 628 & 628 & 628 & 656 & 656 & 656 & 656 \\
\hline
\end{tabular}

This table summarizes the results of quantile regressions of changes in retail and institutional government money market funds on our RORO and BEX indices. Bootstrapped standard errors are clustered by country. 